\title{
Breeding and Selection of New Switchgrass Varieties for Increased Biomass Production
}

Charles M. Taliaferro

Oklahoma State University 


\section{DOCUMENT AVAILABILITY}

Reports produced after January 1, 1996, are generally available free via the U.S. Department of Energy (DOE) Information Bridge.

Web site http://www.osti.gov/bridge

Reports produced before January 1,1996, may be purchased by members of the public from the following source.

National Technical Information Service

5285 Port Royal Road

Springfield, VA 22161

Telephone 703-605-6000 (1-800-553-6847)

TDD 703-487-4639

Fax 703-605-6900

E-mail info@ntis.fedworld.gov

Web site http://www.ntis.gov/support/ordernowabout.htm

Reports are available to DOE employees, DOE contractors, Energy Technology Data Exchange (ETDE) representatives, and International Nuclear Information System (INIS) representatives from the following source.

Office of Scientific and Technical Information

P.O. Box 62

Oak Ridge, TN 37831

Telephone 865-576-8401

Fax 865-576-5728

E-mail reports@adonis.osti.gov

Web site http://www.osti.gov/contact.html

This report was prepared as an account of work sponsored by an agency of the United States Government. Neither the United States Government nor any agency thereof, nor any of their employees, makes any warranty, express or implied, or assumes any legal liability or responsibility for the accuracy, completeness, or usefulness of any information, apparatus, product, or process disclosed, or represents that its use would not infringe privately owned rights. Reference herein to any specific commercial product, process, or service by trade name, trademark, manufacturer, or otherwise, does not necessarily constitute or imply its endorsement, recommendation, or favoring by the United States Government or any agency thereof. The views and opinions of authors expressed herein do not necessarily state or reflect those of the United States Government or any agency thereof. 
Environmental Sciences Division

\section{BREEDING AND SELECTION OF NEW SWITCHGRASS VARIETIES FOR INCREASED BIOMASS PRODUCTION}

Charles M. Taliaferro

Oklahoma State University

Stillwater, Oklahoma

Date Published: December 2002

Prepared for

U.S. Department of Energy

Office of Biomass

Budget Activity No. EB 5203000

Prepared by

OAK RIDGE NATIONAL LABORATORY

Oak Ridge, Tennessee 37831

managed by

UT-BATTELLE, LLC

for the

U.S. DEPARTMENT OF ENERGY

under contract DE-AC05-00OR22725 



\section{CONTENTS}

Page

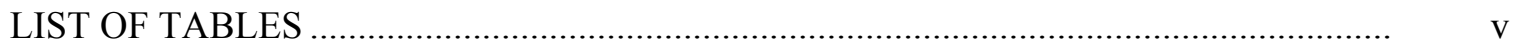

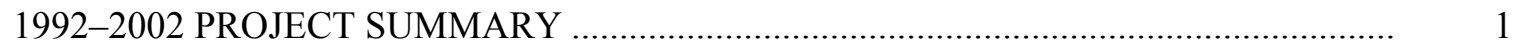

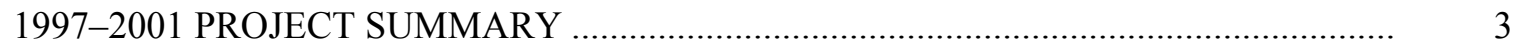

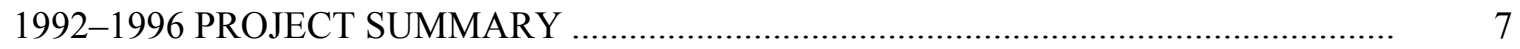

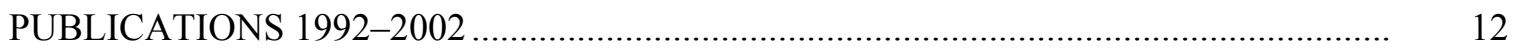

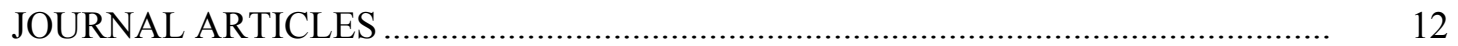

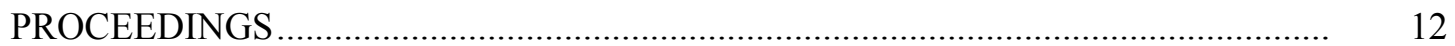

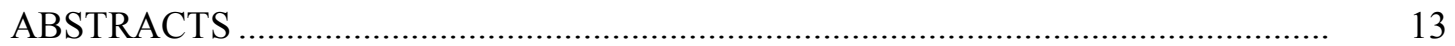

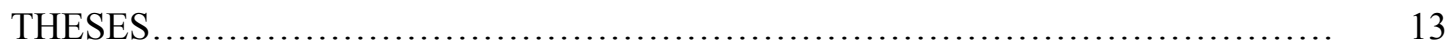

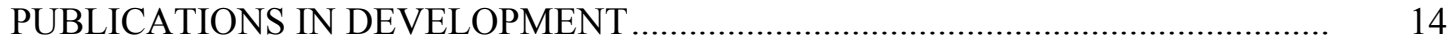

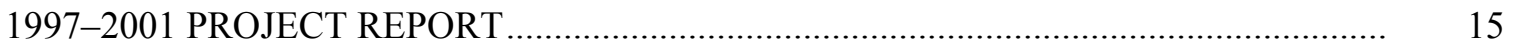

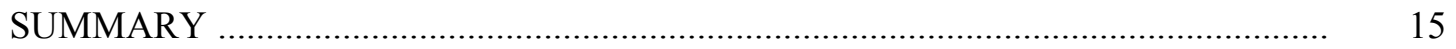

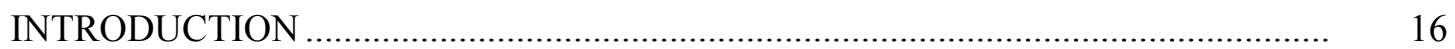

EVALUATION OF BREEDING MATERIALS .................................................. 16

Descriptions of Experiments ............................................................................. 16

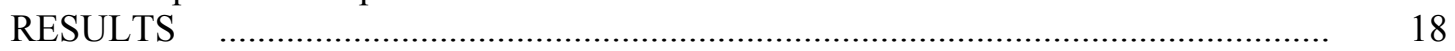

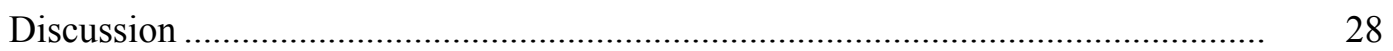

BREEDING RESEARCH ................................................................ 29

Southern Lowland ...................................................................... $\quad 30$

Northern Lowland ........................................................................ $\quad 34$

Early- and Late-Maturing Southern-Northern Upland Populations ......................... $\quad 34$

Inbreeding and Heterosis Studies .................................................................... 38

Heterosis Studies and Feasibility of $F_{1}$ Hybrid Switchgrass ................................ $\quad 38$

Cytological Studies of Interploidy $F_{1}$ Hybrids .................................................. $\quad 39$

Southern Regional Yield Trial ..................................................................... 41

GERMPLASM COLLECTION, EVALUATION, AND ENHANCEMENT ...................... 45

REFERENCES........................................................ 49

APPENDIX

SCALE-UP AND COMMERCIALIZATION OF NEW SWITCHGRASS CULTIVARS

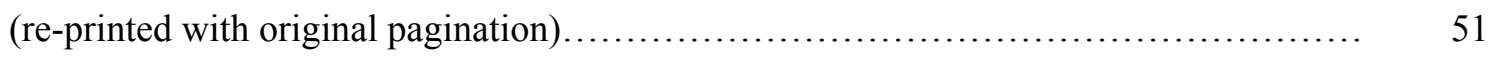





\section{LIST OF TABLES}

Table

Page

1 Three-year mean biomass yields (tons/acre) of experimental lowland synthetic switchgrass cultivars and controls at four regional locations.

2 Three-year mean biomass yields (tons/acre) of experimental upland synthetic switchgrass cultivars and controls in Oklahoma tests.

3 Rank correlations between biomass yield in year 1 and year 2 on an individual plant (Plant rank) and half-sib family mean (HS rank) basis, and number of plants ranking both years among the top 50 (TOP) or bottom 50 (BOTTOM) with regard to biomass yield, for switchgrass nurseries at Perkins and Stillwater, Oklahoma.....

4 Descriptor means, averaged across all available observations for 113 switchgrass germplasm accessions grown at Stillwater, Oklahoma ....

Number of crosses, attempts, and seed set for intra- and interploidy pollination in switchgrass

Number of crosses, attempts, and seed set for intra- and interecotype pollination in switchgrass....

7 Number of crosses, attempts, and seed set for non- and self-pollination in switchgrass

Mean biomass yields of 12 switchgrass cultivars and cultivar blends grown at six locations Information on switchgrass tests planted in 1996

12 Information on switchgrass tests at the NRCS-PMC at Coffeeville, Mississippi, in 1999 .

13 Information on switchgrass upland tests planted in 2000 and 2001

14 Biomass yield (tons/acre) of switchgrass cultivars in the 1996 space-planted lowland yield trial (Test 96-1) at Chickasha, Oklahoma

Biomass yield (tons/acre) of switchgrass cultivars in the 1996 space-planted lowland yield trial (Test 96-3) at Perkins, Oklahoma.....

Mean biomass yield (tons/acre) of switchgrass cultivars in the 1996 spaceplanted lowland yield trials at Chickasha and Perkins, Oklahoma (Tests 96-1 and 96-3).....

Biomass yield (tons/acre) of switchgrass cultivars in the 1996 space-planted

Mean biomass yield (tons/acre) of switchgrass cultivars in the 1996 space-

Mean biomass yield (tons/acre) of switchgrass cultivars in the 1996 spaceplanted upland yield trials at Chickasha and Perkins, Oklahoma (Tests 96-2 and 96-4).

Biomass yield (tons/acre) of switchgrass cultivars evaluated in the 1997 spaceplanted lowland yield trial (Test 97-1) at Chickasha, Oklahoma..........................

21 Biomass yield (tons/acre) of switchgrass cultivars evaluated in the 1997 spaceplanted upland yield trial (Test 97-2) at Chickasha, Oklahoma........................... 


\section{LIST OF TABLES (continued)}

23 Biomass yield of switchgrass lowland cultivars tested by Virginia Polytechnic and State University at Orange, Virginia

24 Biomass yield (tons/acre) of switchgrass cultivars tested by NRCS at Coffeeville, Mississippi

25 Mean performance of cyclic breeding populations relative to their base populations when averaged over different tests

Mean performance of experimental synthetics relative to their controls when averaged over tests......

28 Biomass yield of HYE-C1 and LYE-C1 half-sib families grown in a high-yield environment

32 Biomass yield (tons/acre) for switchgrass cultivars in the 1993 Southern Regional Yield Trial at Chickasha, Oklahoma

33 Biomass yield (tons/acre) of switchgrass cultivars at the 1993 Southern Regional Yield Trial in Haskell, Oklahoma.

34 Mean biomass yield (tons/acre) of switchgrass cultivars in the 1993 Southern Regional Yield Trial in Chickasha and Haskell, Oklahoma

36 Descriptor information for switchgrass germplasm accessions within each of nine clusters 


\section{2-2002 PROJECT SUMMARY}

Switchgrass breeding and genetics research was conducted from 1992-2002 at the Oklahoma State University as part of the national DOE-Bioenergy Feedstock Development Program (BFDP) effort to develop the species as a bioenergy feedstock crop. The fundamental objective of the program was to implement and conduct a breeding program to increase biomass yield capability in switchgrass and develop cultivars for the central and southern United States. Supporting research objectives included: (1) switchgrass germplasm collection, characterization, and enhancement; (2) elucidation of cytogenetic and breeding behavior; and (3) identification of best breeding procedures. Progress in achieving these objectives is summarized as follows:

1. A comprehensive switchgrass germplasm collection comprising 115 accessions was assembled, characterized for cytogenetic and agronomic descriptors, and formed into interbreeding clusters (groups) for long-term preservation and use in breeding and genetics research. Seed production is in progress for nine clusters comprising a total of 110 accessions. Seed of each cluster, when in adequate supply, will be placed in the National Plant Germplasm System (NPGS).

2. Chromosome numbers and ploidy levels were determined for commercial cultivars and unreleased germplasm accessions. Chromosome numbers/ploidy level had not been determined for many commercial switchgrass cultivars and most germplasm accessions in the NPGS when this work began. Additionally, inaccurate chromosome numbers for some switchgrass cultivars had been published. Our research verified previously reported $x=9$ as the basic chromosome number and provided new information indicating mean nuclear DNA sizes of 3.1 and 5.2 pg nucleus $^{-1}$ for tetraploid and octaploid switchgrass.

3. Allozyme inheritance studies mainly in tetraploid switchgrass provided evidence that the inheritance mode in this polyploid species is disomic as opposed to polysomic. The results are expected if specific bivalent chromosome pairing occurs in meiosis as opposed to random bivalent pairing among four copies of chromosomes in autotetraploid plants. Evidence was also found for the presence of duplicate loci in different genomes and that for most of these duplicate loci, one locus on a pair of chromosomes in tetraploids is probably permanently silenced.

4. Breeding characteristics of switchgrass were better defined through experiments estimating levels of self-incompatibility and hybridization (crossability) potential of plants within and among cytotypes and ecotypes. Controlled fertilization experiments were conducted to assess crossability of the different types and levels of self-incompatibility in the species. Very low frequencies of hybrid progeny resulted from attempted crosses of plants with different ploidy levels indicating that gene flow occurs among cytotypes, but at low levels, following classical patterns for other polyploid complexes within the Poaceae (Gramineae). No strong genetic barriers to the hybridization of plants of the same cytotype, but different ecotype, were evident. Self-fertilization results confirmed previous reports of the presence of generally strong self-incompatibility. Tetraploid ( $4 \mathrm{x}=36$ chromosomes) cytotypes tended to be less selffertile than octaploid ( $8 \mathrm{x}=72$ chromosomes) cytotypes. Genetic stocks resulting from the selfing and hybridization experiments are currently being used in breeding and in genetic experiments.

5. The improvement potential for selected important traits was determined by assessing genetic variation within populations and heritabilities. Estimated genetic variances and narrow sense 
heritabilities $\left(\mathrm{h}_{\mathrm{n}}{ }^{2}\right)$ and expected genetic gains from selection for biomass yield were estimated for several switchgrass populations grown in replicated field experiments. The $h_{n}{ }^{2}$ estimates ranged from 0.21 to 0.55 based on half-sib progeny means and from 0.15 to 0.85 based on individual half-sib progeny data. Expected genetic gains based on $\mathrm{h}_{\mathrm{n}}{ }^{2}$ estimates from half-sib progeny mean data ranged from $5 \%$ to $26 \%$ and from individual half-sib progeny data from $8 \%$ to $65 \%$. These results indicated substantial potential for improvement of biomass yield through plant selection based on half-sib family or individual half-sib progeny performance in the switchgrass populations.

6. The presence and magnitude of cultivar by environment interactions and the generally stable and high biomass yield performance of select switchgrass cultivars with minimal nitrogen fertilization were demonstrated. Performance testing of several switchgrass cultivars over 7 years (1994-2000) at two Oklahoma locations (Chickasha and Haskell) identified Alamo and Kanlow as the highest yielding. One application of nitrogen $\left(90 \mathrm{~kg} \mathrm{ha}^{-1}\right)$ each spring produced seasonal total (one harvest at end of growing season) dry biomass yields of 14.9 and 15.4 Mg ha ${ }^{-1}$ for Alamo and Kanlow, respectively. First and second order interactions involving cultivar, location, and year were generally significant. Yields at Haskell were higher than those at Chickasha because of greater annual precipitation. Amount and distribution of precipitation during the growing season was the major determinant of annual biomass yield. The relatively good stability of biomass yield across environments reflects the major strength of switchgrass as a species capable of sustained high production with low input.

7. Breeding was implemented in two lowland and two upland switchgrass populations in 1992 to effect incremental improvement in biomass yield over time and provide commercial cultivars derived from those breeding populations. Three cycles of Restricted Recurrent Phenotypic Selection (RRPS) were completed in the two upland and two lowland ecotype populations from 1992 through 1996. Information gained during this period provided new insight on "best breeding methodology" and permitted refinements to be implemented in the breeding procedure. Genotypic Recurrent Selection [(GRS) (plant selection based on half-sib progeny performance)] was adopted in 1997. One cycle of GRS was completed in two lowland populations, and a second cycle initiated, during the period 1997-2002. One cycle of GRS is nearing completion in two upland populations, one early maturing and the other late maturing. Recurrent selection generally increased biomass yields and allowed the development of experimental synthetic cultivars using elite plants from the respective breeding populations.

8. Fifteen experimental synthetic cultivars were developed and field-tested to determine their potential for commercialization. Three of the 15 (SL94-1, SL93-3, and NL94-1) are in final stages of evaluation. Johnston's Seed Company, Enid, Oklahoma, is evaluating seed production and other performance characteristics of the three cultivars under an agreement with the Oklahoma State University. One, two, or all three of the cultivars may be commercialized by Johnston's, contingent on their findings. Twenty-five new experimental synthetic cultivars were developed in 2001 and were recently (5/2002) planted in field performance tests. 
Breeding procedures were refined based on findings over the preceding 5 years. The essential change was in the criterion for selection of plants to use as parents to generate new populations for cyclic breeding. Selection from 1992-1997 was based on the phenotype (phenotypic recurrent selection) of individual plants (i.e., their biomass yield). Selection since 1997 has been based on a combination of phenotypic and genotypic performance with final selection based on genotype (breeding value) as measured by the biomass yield performance of their half-sib progeny. The procedure used since 1997 has been referred to in previous reports as genotypic recurrent selection (GRS).

The GRS procedure (Fig.1) has been applied to two lowland and two upland populations since 1997. One cycle of GRS was completed and a second cycle is nearing completion in a population of plants designated as Northern Lowland (NL), initially synthesized from Kanlow and Pangburn. In conjunction with GRS in this population, an experiment was started in 1997 to assess the effects of yield environment (low and high) on selection. The results of the experiment will provide information on whether cultivars developed under one set of conditions (low yield or

Yr 1.

- Selection nursery established (10001200 plants).

- Half-sib seed harvested from about $20 \%(200-240)$ of plants.

口 Seed conditioned.

Yr 2.

- Half-sib seed germinated.

- About $65 \%$ of half-sib families with best seed germination and seedling vigor selected.

- Half-sib progeny selected field evaluation nursery established.

口 Biomass yield measured in fall.

Yr 3.

口 Biomass yield measured in fall.

- Data analyzed.

- Parent plants selected if correlation between first and second harvest is good.

Yr 4.

- Parents of top 40 half-sib families (30\% selection index) cloned to field polycross nurseries in early spring.

- Seed from polycross block harvested in fall.

Selection Nursery

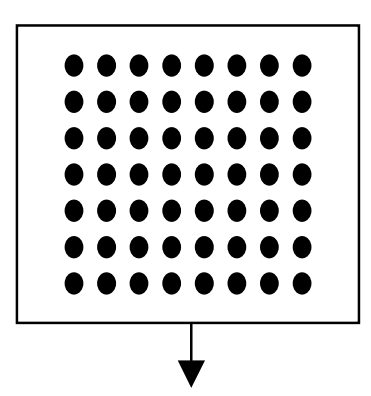

Half-Sib Progeny Nursery
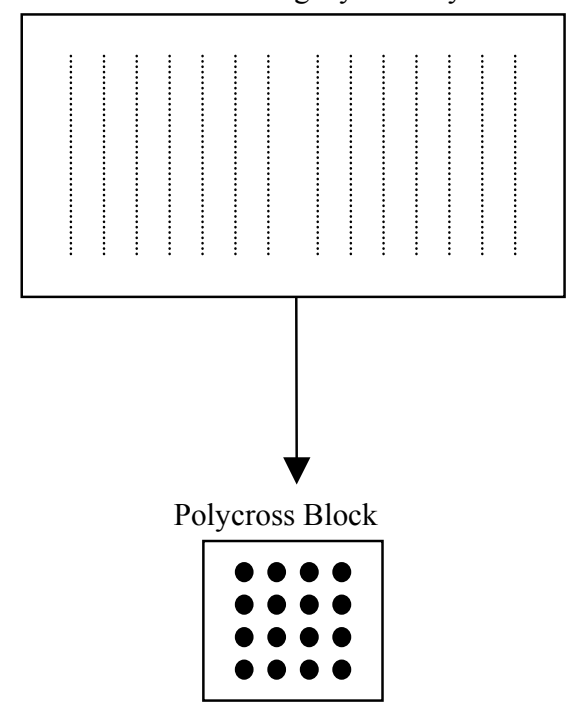

Fig. 1. Genotypic recurrent selection procedure for switchgrass population improvement at Oklahoma State University. 
high yield) will maintain performance when grown under the other set of conditions. We started in 1997 with a base population (NL94 $\mathrm{C}_{0}$ ) comprising 65 plants from the NL 94 selection nursery and evaluated clonal sets of their half-sib progenies under a high-yield environment (HYE) and a low-yield environment (LYE). The HYE was achieved by growing on a fertile soil, annual application of fertilizer ( $71 \mathrm{~kg} \mathrm{~N} \mathrm{ha}^{-1} \mathrm{yr}^{-1}+\mathrm{P}$ and $\mathrm{K}$ as indicated by soil test), and irrigation to maintain growth during drought periods. The LYE utilized a less productive soil, no supplemental fertilizer, and no irrigation. Parent plants selected on the basis of the half-sib performance were intercrossed in 1999 to produce new cyclic populations designated

NL94-HYE $\mathrm{C}_{1}$ and NL94-LYE $\mathrm{C}_{1}$. Selection nurseries (1020 plants) of each were established, and half-sib seed of 240 plants harvested in year 2000. In spring 2001, 130 half-sib families (65 each from the NL94-HYE $\mathrm{C}_{1}$ and NL94-LYE $\mathrm{C}_{1}$ ) were planted in low- and high-yield environments for performance testing. Biomass yields were measured in 2001 and will again be measured in 2002. The 2001 and 2002 yields will be used to test the hypothesis that the mean biomass yield of half-sib families from the NL94 HYE $\mathrm{C}_{1}$ is equal to that of half-sib families from the NL94-LYE C ${ }_{1}$.

One cycle of GRS has been completed in a second population designated as southern lowland (SL), and a second cycle will be completed in this population in 2002. The SL base population was synthesized in 1993 from plants of Alamo, PMT-279, and PMT-785. Accordingly, the population is best adapted to the southern half of the targeted region of the breeding program.

Both the NL and the SL populations had undergone three cycles of RRPS through 1996, at which time the procedure was changed to GRS.

Upland switchgrass breeding populations were merged into early- and late-maturing populations for continued GRS. Two populations that we designated as southern upland (SU) and northern upland (NU) were synthesized in 1993. The SU population was formed from Caddo, Blackwell and other accessions from Kansas, Oklahoma, and Texas. Plants of NE-28, Cave-in-Rock, and Pathfinder were intercrossed to form the NU population. Three cycles of phenotypic recurrent selection were completed in the SU and NU populations through 1996. Beginning in 1997, we merged the two populations into early- and late-maturing populations for GRS. The early- and late-maturing populations were formed respectively by recombining early- or late-maturing plants selected from both the SU and NU populations. The two populations differ in mean days to flowering by about 2 weeks with substantial variation for heading time remaining in each. Selection nurseries $(\approx 1000$ plants each) of the early-maturing southern-northern upland (EMSNU) and late-maturing southern-northern upland (LMSNU) populations were planted in 2000. Half-sib seed was harvested from about 100 plants from each nursery in fall 2001. Selection in each nursery was based primarily on heading date (early or late) and secondarily on plant vigor and general appearance. Some selections within each population were discarded on the basis of seed quantity/quality or seedling vigor. Half-sib progeny plants and clonal parents of the progeny plants were planted in evaluation nurseries in spring 2002 and will be evaluated at least through fall 2003. Response variables will include days to heading and biomass yield. Parent clones and progeny plants are included in different tests at different locations to provide the necessary data to allow estimation of genetic parameters.

The development and commercialization of new cultivars with increased biomass yield capability has been a central goal of our breeding program. Several experimental synthetic switchgrass cultivars developed by our program have performed well in current regional testing. For example, the biomass yield of the experimental synthetic SL 93-3, averaged over all regional tests after 3 years of testing, was $9 \%$ higher than the biomass yield of Alamo (Table 1). In Orange County, Virginia, the 3-year mean yield advantage of SL 93-3 over Alamo was 26\%. The 3-year 
Table 1. Three-year mean biomass yields (tons/acre) of experimental lowland synthetic switchgrass cultivars and controls at four regional locations

\begin{tabular}{lccccccccc}
\hline & \multicolumn{2}{c}{$\begin{array}{c}\text { Manhattan, } \\
\text { Kansas }\end{array}$} & \multicolumn{2}{c}{$\begin{array}{c}\text { Booneville, } \\
\text { Arkansas }\end{array}$} & \multicolumn{2}{c}{$\begin{array}{c}\text { Orange, } \\
\text { Virginia }\end{array}$} & \multicolumn{2}{c}{$\begin{array}{c}\text { Chickasha, } \\
\text { Oklahoma }\end{array}$} & $\begin{array}{c}\text { Overall } \\
\text { mean }\end{array}$ \\
\hline Entry & Mean & \% Alamo & Mean & \% Alamo & Mean & \% Alamo & Mean & \% Alamo & \% Alamo \\
\hline SL94-1 & 3.00 & 85 & 7.13 & 115 & 6.56 & 106 & 6.88 & 108 & 104 \\
SL93-3 & 3.42 & 97 & 6.78 & 109 & 7.81 & 126 & 6.54 & 103 & 109 \\
SL93-2 & 3.46 & 98 & 6.88 & 111 & 6.07 & 98 & 5.93 & 93 & 100 \\
SL93-1 & 2.94 & 84 & 7.52 & 121 & 6.38 & 103 & 6.76 & 106 & 104 \\
SL 92-1 & & & & & 6.42 & 104 & 6.51 & 102 & 103 \\
Alamo & 3.52 & 100 & 6.22 & 100 & 6.2 & 100 & 6.37 & 100 & \\
& & & & & & & & & \\
\hline Entry & Mean & \% Kanlow & Mean & \% Kanlow & Mean & \% Kanlow & Mean & \% Kanlow \% Kanlow \\
\hline NL94-1 & 3.42 & 113 & 6.58 & 101 & 6.11 & 108 & 6.9 & 108 & 108 \\
NL93-SP & 3.04 & 100 & 6.61 & 101 & 5.93 & 105 & & & 102 \\
NL93-1 & 2.82 & 93 & 7.45 & 114 & 5.62 & 99 & 6.51 & 102 & 102 \\
NL 93-2 & & & & & 5.31 & 94 & 5.78 & 91 & 93 \\
Kanlow & 3.04 & 100 & 6.53 & 100 & 5.66 & 100 & 6.38 & 100 & \\
\hline
\end{tabular}

mean yield advantage for the experimental synthetic NL 94-1 averaged over all regional tests was $8 \%$ greater than that of Kanlow. At Manhattan, Kansas, NL 94-1 produced 13\% more dry biomass than Kanlow. Mean biomass yield of the upland synthetic SU 94-1 has exceeded that of Caddo in Oklahoma tests by $19 \%$ (Table 2).

Table 2. Three-year mean biomass yields (tons/acre) of experimental upland synthetic switchgrass cultivars and controls in Oklahoma tests

\begin{tabular}{lccccc}
\hline & \multicolumn{2}{c}{ 1996 Test } & \multicolumn{2}{c}{ 1997 Test } & Overall mean \\
\hline Entry & Mean & $\mathbf{\% ~ C ~}_{\mathbf{0}}$ & Mean & $\mathbf{\% ~ C ~}_{\mathbf{0}}$ & $\mathbf{\% ~ C}_{\mathbf{0}}$ \\
\hline SU 92-1 & 4.29 & 115 & 5.72 & 110 & 112 \\
SU 94-1 & & & 6.16 & 119 & 119 \\
SU C & & 100 & 5.19 & 100 & 100 \\
NU 94-1 & 3.74 & 114 & 5.89 & 120 & 117 \\
NU 92-1 & 4.20 & 121 & & & 121 \\
NU 94-2 & 4.46 & & 5.85 & 119 & 119 \\
NU C & & 100 & 4.90 & 100 & 100 \\
\hline
\end{tabular}

Three experimental synthetic cultivars (SL94-1, SL93-3, and NL94-1) are in final stages of evaluation. Johnston's Seed Company, Enid, Oklahoma, is evaluating seed production and other performance characteristics of the three cultivars under an agreement with the Oklahoma State University. One, two, or all three of the cultivars may be commercialized by Johnston's, contingent on their findings. Release will follow the appended plan, "Scale-up and Commercialization of New Switchgrass Cultivars."

In 2001, we synthesized 25 new switchgrass experimental synthetic lines for evaluation as potential new commercial cultivars. The parents were selected based on half-sib progeny performance. Four of the new experimental synthetics comprise six or more parents. Twenty-one 
of the synthetics are single crosses resulting from a diallel mating of seven elite parents (three from NL 94 and four from SL 93 breeding nurseries). The diallel mating is designed to test for their general and specific combining abilities, to determine and quantify the presence of heterosis in switchgrass, and to evaluate the feasibility of development and deployment of 2-clone, Syn-1 generation, hybrid cultivars with increased biomass potential. Syn-1 seed was harvested in fall 2001. These new experimental synthetic cultivars were planted in a performance test in spring 2002.

A decade ago there was no substantive switchgrass germplasm collection from which materials with known characteristics could be obtained. We amassed a switchgrass germplasm collection currently comprising 115 accessions. The accessions have been characterized for cytogenetic, morphological, and agronomic descriptors. Cluster analysis of descriptor data was used to aid in separating 110 of the accessions into nine core groups. Accessions within each core group were planted in isolated crossing blocks in 2001 to produce random mating populations. Long term maintenance of switchgrass germplasm collections and preservation of genetic diversity within those collections is more easily and economically achieved via random mating populations compared to maintenance of many closely related individual accessions. Seed of each core group will be maintained by us and offered, along with descriptor data, to the NPGS for inclusion in their collection. This will provide a well-characterized switchgrass germplasm resource for use in research.

New information was gained on the type of polyploidy (allopolyploidy vs. autopolyploidy) present and the consequent mode (disomic vs. polysomic) of inheritance in switchgrass. Segregation of allozymes at Adh-1 and Got-2 loci in tetraploid self-progenies conformed to expected disomic ratios, and significantly differed from expected tetrasomic ratios. The results indicate specific bivalent chromosome pairing in meiosis as opposed to random bivalent pairing among four copies of chromosomes in tetraploid plants. Progeny analyses of phosphoglucomutase (PGM), leucine aminopeptidase (LAP), and phosphoglucose isomerase (PGI) indicated the presence of duplicate genes for these enzyme systems, each gene having only one allozyme form that is paired with a null allele. For most of these duplicate genes, one pair of chromosomes in tetraploids is probably permanently silenced. Comparison of isoenzyme patterns among tetraploid, hexaploid, and octaploid cultivars suggests that gene duplications leading to different forms occurred mainly at a low ploidy level or in a common ancestral genome.

Genetic variances, narrow sense heritabilities $\left(\mathrm{h}_{\mathrm{n}}{ }^{2}\right)$ and expected genetic gains from selection for biomass yield were estimated for several switchgrass populations grown in replicated field experiments. The $\mathrm{h}_{\mathrm{n}}{ }^{2}$ estimates ranged from 0.21 to 0.55 based on half-sib progeny means and from 0.15 to 0.85 based on individual half-sib progeny data. Expected genetic gains based on $\mathrm{h}_{\mathrm{n}}{ }^{2}$ estimates from half-sib progeny mean data ranged from $5 \%$ to $26 \%$ and from individual half-sib progeny data from $8 \%$ to $65 \%$. These results indicated substantial potential for improvement of biomass yield through half-sib family or individual half-sib progeny selection in the switchgrass populations. 


\section{2-1996 PROJECT SUMMARY}

Recurrent Restricted Phenotypic Selection (RRPS) was initiated in 1992 in each of four switchgrass populations respectively designated as northern upland (NU), southern upland (SU), northern lowland (NL), and southern lowland (SL). The germplasms used in synthesizing the four breeding populations in 1991 were from central and southern states, thus "northern" and "southern" distinguished the populations on the basis of latitude of origin of the founding plant materials within this geographic region. The terms "upland" and "lowland" refer to ecotypes adapted to nonalluvial and alluvial soils, respectively. Our initial goal was to complete one cycle of RRPS per year following the procedures outlined by Burton $(1974 ; 1982)$ in breeding bahiagrass, Paspalum notatum.

Additional research was initiated concurrently with the breeding to provide switchgrass germplasm resources and basic information needed to facilitate long-term breeding and genetic investigations. Specific supporting objectives were to: (1) assemble a comprehensive switchgrass germplasm collection and characterize individual accessions for standard cytological, agronomic, morphological and physiological traits (descriptors); (2) better characterize breeding behavior in terms of self-fertility / incompatibility and hybridization potential (crossability) between ecotypic and chromosome ploidy morphs; (3) assess yield performance of cultivars and cultivar blends; and (4) assess acidity tolerance in selected populations.

Progress in achieving the objectives during the period 1992-1996 follows:

1. Three cycles of RRPS were completed in the SL, NL, SU, and NU populations. Data were obtained comparing the feasibility of selection based on individual plant yield performance (phenotypic) vs. half-sib family yield performance (genotypic). This information identified modifications needed in breeding methodology to enhance selection effectiveness.

Biomass yield of plants in the establishment year was not highly predictive of yield in the post-establishment year(s) (Table 3). Rank correlations for biomass yields in different years were in most cases positive and significant, but higher when based on half-sib performance compared to individual plant performance. Completion of one cycle of selection per year was hindered by the inability in many instances to produce adequate polycross seed in a timely manner either by use of detached flowering culms or by growing plants during the winter in the greenhouse. Consequently, the utility of "fast-track" RRPS in switchgrass is limited. Data (see discussion in next section and associated tables) indicated genetic gains from selection in some populations but not in others. Breeding methodology was modified to include selection based on post-establishment year yield performance of half-sib progeny families.

2. A comprehensive switchgrass germplasm collection comprised of 115 accessions was assembled and evaluations initiated for standard reproductive and performance descriptors.

Ploidy level was determined for the accessions by counting chromosomes in mitotic or meiotic cells, or by flow cytometry measurement of nuclear DNA, or both. Data for 12 additional standard descriptors of agronomic, adaptive, and reproductive traits were obtained (Table 4). Both upland and lowland accessions with desirable adaptive and agronomic characteristics were identified. Examples are AL-5 and TN-104, upland types collected in 1993 from northern Alabama and Tennessee, respectively, and lowland accession SWG 50, collected in eastern Oklahoma. 
Table 3. Rank correlations between biomass yield in year 1 and year 2 on an individual plant (Plant rank) and half-sib family mean (HS rank) basis, and number of plants ranking both years among the top 50 (TOP) or bottom 50 (BOTTOM) with regard to biomass yield, for switchgrass nurseries at Perkins and Stillwater, Oklahoma

\begin{tabular}{ccccc}
\hline Nursery & $\begin{array}{c}\text { Plant } \\
\text { Rank }\end{array}$ & $\begin{array}{c}\text { HS } \\
\text { Rank }\end{array}$ & Top & Bottom \\
\hline $\mathrm{SL} \mathrm{C}_{0}$ & $0.49^{\mathrm{a}}$ & & 14 & 19 \\
$\mathrm{NL} \mathrm{C}_{0}$ & $0.49^{\mathrm{a}}$ & & 6 & 17 \\
$\mathrm{SU} \mathrm{C}_{0}$ & $0.75^{\mathrm{a}}$ & & 13 & 26 \\
$\mathrm{SL} \mathrm{C}_{1}$ & $0.49^{\mathrm{a}}$ & $0.78^{\mathrm{a}}$ & 10 & 15 \\
$\mathrm{NL} \mathrm{C}_{1}$ & $0.32^{\mathrm{a}}$ & $0.56^{\mathrm{a}}$ & 8 & 11 \\
$\mathrm{SU} \mathrm{C}_{1}$ & $0.59^{\mathrm{a}}$ & $0.80^{\mathrm{a}}$ & 0 & 9 \\
$\mathrm{NU} \mathrm{C}_{1}$ & $0.46^{\mathrm{a}}$ & $0.58^{\mathrm{a}}$ & 7 & 14 \\
$\mathrm{SL} \mathrm{C}_{2}$ & $0.47^{\mathrm{a}}$ & $0.56^{\mathrm{a}}$ & 4 & 22 \\
$\mathrm{NL} \mathrm{C}_{2}$ & $0.64^{\mathrm{a}}$ & $0.84^{\mathrm{a}}$ & 17 & 17 \\
$\mathrm{SU} \mathrm{C}_{2}$ & $0.39^{\mathrm{a}}$ & 0.37 & 5 & 16 \\
$\mathrm{NU} \mathrm{C}_{2}$ & $0.39^{\mathrm{a}}$ & $0.36^{\mathrm{b}}$ & 14 & 12 \\
$\mathrm{SU} \mathrm{C}_{3}$ & $0.43^{\mathrm{a}}$ & $0.49^{\mathrm{b}}$ & 8 & 4 \\
$\mathrm{NU} \mathrm{C}_{3}$ & $0.54^{\mathrm{a}}$ & $0.55^{\mathrm{a}}$ & 9 & 13 \\
\hline
\end{tabular}

${ }^{\mathrm{a}}$ Significant at the 0.01 probability level.

${ }^{\mathrm{b}}$ Significant at the 0.05 probability level.

3. Breeding characteristics of switchgrass were better defined through experiments estimating levels of self-incompatibility and hybridization (crossability) of plants within and among ploidy types and ecotypes.

Very low frequencies of hybrid progeny resulted from attempted crosses of plants with different ploidy levels (ploidy types) (Table 5). This suggested that gene flow occurs among cytotypes, but at low levels, following classical patterns for other polyploid complexes within the Poaceae (Gramineae). No strong genetic barriers to the hybridization of plants of the same ploidy type, but different ecotype, were evident (Table 6). Self-fertilization experiments confirmed the presence of generally strong self-incompatibility. Tetraploids $(4 \mathrm{x}=36$ chromosomes) tended to be less self-fertile than octaploids $(8 x=72$ chromosomes) (Table 7$)$. Genetic stocks resulting from the selfing and hybridization experiments have been used in experiments to determine chromosome pairing behavior, type of polyploidy (allo- or autopolyploidy) and mode of inheritance (polysomic or disomic) in switchgrass. 
Table 4. Descriptor means, averaged across all available observations for 113 switchgrass germplasm accessions grown at Stillwater, Oklahoma

\begin{tabular}{|c|c|c|c|}
\hline Descriptor & Mean & Range & Notes \\
\hline $\begin{array}{l}\text { Biomass yield } \\
\text { (g/plant) }\end{array}$ & 1189 & $26-3260$ & Expressed on a dry matter basis. \\
\hline Height $(\mathrm{cm})$ & 161 & $58-247$ & \\
\hline Heading date & 215 & $167-245$ & $\begin{array}{l}\text { Date on which the majority of plants in a plot have three or more } \\
\text { panicles fully exerted above the flag leaf. } 1=1 \text { January, } \\
365=\text { December } 31\end{array}$ \\
\hline Ecotype & 2 & $1-3$ & $1=$ lowland, $2=$ intermediate, $3=$ upland \\
\hline \# Nodes & 7 & $3-9$ & \\
\hline Panicle & 7 & $5-9$ & $1=$ fewest panicles, $9=$ most panicles \\
\hline Leafiness & 6 & $4-8$ & $1=$ least proportion of leaves, $9=$ greatest proportion of leaves \\
\hline Pubescence & 2 & $1-7$ & $\begin{array}{l}1=\text { no pubescence on leaf blade, } 9=\text { greatest amount of } \\
\text { pubescence on leaf blade }\end{array}$ \\
\hline Disease & 7 & $3-9$ & $\begin{array}{l}1=\text { greatest amount of foliar disease, } 9=\text { least amount of foliar } \\
\text { disease }\end{array}$ \\
\hline Color & 3 & $2-5$ & $1=$ light green, $2=$ green, $3=$ dark green, $4=$ blue green, $5=$ blue \\
\hline Shattering & 6 & $3-9$ & $\begin{array}{l}\text { Degree of seed loss prior to biomass harvest. } 1=\text { greatest amount } \\
\text { of seed loss, } 9=\text { least amount of seed loss }\end{array}$ \\
\hline Type & 7 & $5-9$ & $1=$ prostrate growth habit, $9=$ upright growth habit \\
\hline
\end{tabular}

Table 5. Number of crosses, attempts, and seed set for intra- and interploidy pollination in switchgrass

\begin{tabular}{|c|c|c|c|c|c|}
\hline Class & Crosses & Average seed set $^{\mathrm{a}}$ & Range & Attempts & Seed set \\
\hline \multicolumn{5}{|c|}{ Intraploidy } & \\
\hline $4 \mathrm{x} \times 4 \mathrm{x}$ & 32 & $15.30+3.34$ & $0-63.80$ & 1260 & 210 \\
\hline $8 \mathrm{x} \times 8 \mathrm{x}$ & 55 & $10.51+2.51$ & $0-60.00$ & 1745 & 210 \\
\hline $6 \mathrm{x} \times 6 \mathrm{x}$ & 6 & $0.97 \pm 0.53$ & $0-3.03$ & 243 & 2 \\
\hline Total & 93 & $11.65 \pm 1.90$ & $0-63.80$ & 3248 & 422 \\
\hline \multicolumn{6}{|c|}{ Interploidy } \\
\hline $8 \mathrm{x} \times 4 \mathrm{x}$ & 129 & $0.40 \pm 0.10$ & $0-6.25$ & 4766 & 31 \\
\hline $4 x \times 8 x$ & 71 & $0.11 \pm 0.07$ & $0-4.35$ & 3397 & 4 \\
\hline $6 x \times 8 x$ & 7 & $0.19+0.19$ & $0-1.32$ & 348 & 1 \\
\hline $8 \times \times 6 x$ & 1 & 0.00 & 0 & 23 & 0 \\
\hline $6 \mathrm{x} \times 4 \mathrm{x}$ & 10 & $2.13+0.98$ & $0-8.57$ & 466 & 8 \\
\hline Total & 218 & $0.38+0.08$ & $0-8.57$ & 9000 & 44 \\
\hline
\end{tabular}

${ }^{\mathrm{a}} \pm$ standard error of the mean. 
Table 6. Number of crosses, attempts, and seed set for intra- and interecotype pollination in switchgrass

\begin{tabular}{|c|c|c|c|c|c|}
\hline Class & Crosses & Average seed set $^{a}$ & Range & Attempts & Seed set \\
\hline & $\mathrm{N}$ & \multirow{2}{*}{\multicolumn{2}{|c|}{ 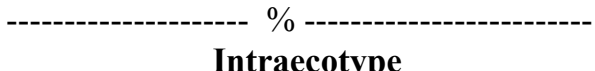 }} & \multicolumn{2}{|c|}{---------------------- \% \% ------------------ } \\
\hline & & & & & \\
\hline SEDP $^{b}$ & 42 & $0.65 \pm 0 . \overline{22}$ & $0-04.88$ & 1604 & 15 \\
\hline SESP & 78 & $10.77+2.02$ & $0-60.00$ & 2630 & 337 \\
\hline \multirow[t]{2}{*}{ Total } & 120 & $7.23 \pm 1.39$ & $0-60.00$ & 4234 & 352 \\
\hline & \multicolumn{3}{|c|}{ Interecotype } & & \\
\hline DESP & 9 & $25.24 \pm \overline{7.36}$ & $0-63.80$ & 375 & 83 \\
\hline DEDP & 158 & $0.21 \pm 0.07$ & $0-06.25$ & 6559 & 20 \\
\hline Total & 167 & $1.56 \pm 0.69$ & $0-63.80$ & 6934 & 103 \\
\hline
\end{tabular}

Table 7. Number of crosses, attempts, and seed set for non- and self-pollination in switchgrass

\begin{tabular}{|c|c|c|c|c|c|}
\hline Class & Crosses & Average seed set ${ }^{\mathrm{a}}$ & Range & Attempts & Seed set \\
\hline & $\mathrm{N}$ & - & ------------- n & 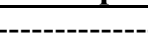 & ---------. \\
\hline No pollen & 35 & $0.11 \pm 0.11$ & $0-03.70$ & 772 & 1 \\
\hline $6 x$ self & 12 & $0.96 \pm 0.49$ & $0-04.68$ & 3963 & 30 \\
\hline \multicolumn{6}{|c|}{ Upland self } \\
\hline $4 \mathrm{x}$ & 6 & $1.49 \pm 0.99$ & $0-06.30$ & 3414 & 48 \\
\hline $8 \mathrm{x}$ & 30 & $6.91 \pm 1.82$ & $0-34.80$ & 7015 & 399 \\
\hline Total & 36 & $6.00 \pm 1.56$ & $0-34.80$ & 10429 & 447 \\
\hline \multicolumn{6}{|c|}{ Lowland self } \\
\hline $4 \mathrm{x}$ & 25 & $1.18 \pm \overline{1.05}$ & $0.0-26.30$ & 11888 & 183 \\
\hline $8 \mathrm{x}$ & 2 & $0.12 \pm 0.03$ & $0.1-0.15$ & 1700 & 2 \\
\hline Total & 27 & $1.10 \pm 0.97$ & $0.0-26.30$ & 13588 & 185 \\
\hline
\end{tabular}

4. Level of, and genetic variation for, seedling acid soil tolerance were characterized in Blackwell (upland octaploid) and Kanlow (lowland tetraploid) plant populations.

Both Blackwell and Kanlow were highly tolerant of acid soils ranging in $\mathrm{pH}$ from 4.4 to 5.1 as indicated by seedling biomass weights. Heritability estimates for acid soil tolerance were low, or non-significant, in both populations. Accordingly, breeding for increased acid soil tolerance in switchgrass is not warranted because of existing high tolerance and the low probability of success indicated by low heritability for the trait. 
5. Genotype by environment interactions were estimated for switchgrass cultivars and cultivar blends in regional trials at six locations across the southeastern United States.

Seeded sward plots were established in spring 1993 at Haskell and Chickasha, Oklahoma; Stephenville and College Station, Texas; Auburn, Alabama; and Blacksburg, Virginia. Nine cultivars and three cultivar blends were included in the tests. Biomass yields were measured at all locations in 1994-1995 and at the two Oklahoma locations in 1996. Substantial interactions occurred encompassing cultivars, locations, and years. Lowland ecotypes were generally more productive than upland ecotypes; Alamo or blends containing Alamo often produced the highest yields (Table 8). The two Oklahoma experiments are being continued to provide information on long-term productivity of upland vs. lowland types in the south central Great Plains.

Table 8. Mean biomass yields of 12 switchgrass cultivars and cultivar blends grown at six locations ${ }^{\mathrm{a}}$

\begin{tabular}{lcrrrrr}
\hline Entry & AAL $^{\mathbf{b}}$ & BVA $^{\mathbf{b}}$ & $\mathbf{C O K}^{\mathbf{b}}$ & $\mathbf{H O K}^{\mathbf{b}}$ & CSTX $^{\mathbf{b}}$ & STX $^{\mathbf{b}}$ \\
\hline & - & 11739 & 16265 & 9659 & 22240 & 15995 \\
Alamo + Summer & 9887 & 13142 & 16240 & 11490 & 22063 & 17589 \\
Alamo & 8008 & 11280 & 13201 & 6121 & 19417 & 11330 \\
Blackwell + Kanlow & 6375 & 10968 & 11872 & 3998 & 16049 & 6944 \\
Blackwell & 4208 & 8705 & 11705 & 4120 & 15745 & 8048 \\
Caddo & 5102 & 8247 & 5490 & 16770 & 5211 \\
Cave-in-Rock & 3602 & 12959 & 16320 & 8184 & 22162 & 14193 \\
Kanlow + Alamo & 9697 & 12856 & 17700 & 6814 & 18714 & 13089 \\
Kanlow & 7284 & 013482 & 12850 & 3626 & 15767 & 7401 \\
Late Synthetic & 2490 & 11304 & 15377 & 6119 & 18167 & 13297 \\
PMT-279 & 8197 & 11582 & 7024 & 2948 & 14881 & 2915 \\
Shelter & 3120 & 11187 & 7963 & & 10002 & 1598 \\
Summer & 4433 & 9701 & & & & $\mathrm{~kg} \mathrm{ha}^{-1}$ \\
\hline
\end{tabular}

${ }^{\mathrm{a}}$ Mean of 94-95 except HOK and COK, which are 94-96.

${ }^{\mathrm{b}} \mathrm{AAL}=$ Auburn, Alabama; BVA = Blacksburg, Virginia; $\mathrm{COK}=$ Chickasha, Oklahoma; $\mathrm{CSTX}=$ College Station, Texas; HOK = Haskell, Oklahoma; STX = Stephenville, Texas. 


\section{PUBLICATIONS 1992-2002}

\section{JOURNAL ARTICLES}

Hopkins, A. A., C. M. Taliaferro, C. D. Murphy, and D. Christian. 1996. Chromosome number and nuclear DNA content of several switchgrass populations. Crop Sci. 36:1192-1195.

Hopkins, A. A., and C. M. Taliaferro. 1997. Genetic variation within switchgrass populations for acid soil tolerance. Crop Sci. 37:1719-1722.

Sanderson, M. A., R. L. Reed, S. B. McLaughlin, S. D. Wullschleger, B. V. Conger, D. J. Parrish, D. D. Wolf, C. Taliaferro, A. A. Hopkins, W. R. Ocumpaugh, M. A. Hussey, J. C. Read, and C. R. Tischler. 1996. Switchgrass as a sustainable bioenergy crop. Bioresource Technology 56:83-93.

\section{PROCEEDINGS}

Fuentes, R. G., and C. M. Taliaferro. 2002. Biomass yield stability of switchgrass (Panicum virgatum L.) cultivars. In Proceedings of the Conference on New Crops and New Uses, Atlanta, Nov. 10-13, 2001.

Hopkins, A. A., and C. M. Taliaferro. 1995. A comparison of selection strategies in switchgrass. pp. 190-192. In Proceedings of the American Forage and Grassland Council, Lexington, Ky., Mar. 12-14, 1995.

McLaughlin, S. B., J. Bouton, D. Bransby, R. Conger, W. Ocumpaugh, D. Parrish, C. Taliaferro, K. Vogel, and S. Wullschleger. 1999. Developing switchgrass as a bioenergy crop. pp. 282-292. In J. Janick (ed.), Proceedings of the Symposium New Crops and New Uses: Biodiversity and Agricultural Sustainability, Phoenix Ariz., Nov. 1998.

Taliaferro, C. M., and A. A. Hopkins. 1996. Breeding characteristics and improvement potential of switchgrass. 1996. pp. 2-9. In J. S. Cundiff, E. E. Gavett, C. Hansen, C. Peterson, M. A. Sanderson, H. Shapouri, and D. L. VanDyne (eds.), Proceedings of the Third Liquid Fuels Conference: Liquid Fuels and Industrial Products from Renewable Resources, Nashville, Tenn., Sept. 15-17, 1996. Amer. Soc. Agric. Eng.

Taliaferro, C. M., A. A. Hopkins, M. P. Anderson, and J. A. Anderson. 1996. Breeding and genetic studies in Bermuda grass and switchgrass. pp. 41-52. In Proceedings of the 52nd Southern Pasture and Forage Crop Improvement Conference, Oklahoma City, Okla., March 30Apr. 2, 1996.

Taliaferro, C. M., K. P. Vogel, J. H. Bouton, S. B. McLaughlin, and G. A. Tuskan. 1999. Reproductive characteristics and breeding improvement potential of switchgrass. pp. 147-153. In Proceedings of the 4th Biomass Conference of the Americas, Oakland, Calif., Aug. 29-Sept. 2, 1999. 


\section{ABSTRACTS}

Casler, M. D., K. P. Vogel, C. M. Taliaferro, and R. Wynia. 2001. Latitudinal adaptation of switchgrass populations. Agronomy Abstracts, American Society of Agronomy, Madison Wis. http://www.annualmeeting2001.com/Abstracts/

Das, M. K., and C. M. Taliaferro. 2000. Heritability of biomass yield in switchgrass. p. 101. Agronomy Abstracts, American Society of Agronomy, Madison Wis.

Fuentes, R. G., and C. M. Taliaferro. 2001. Performance of switchgrass half-sib progeny families under high- and low-biomass yield environments. Agronomy Abstracts, American Society of Agronomy, Madison Wis. http://www.annualmeeting2001.com/Abstracts/.

Gunter, L. E., S. D. Wullschleger, G. A. Tuskan, C. M. Taliaferro, and A. A. Hopkins. 1996. Characterization of switchgrass accessions using RAPD markers and morphological descriptor data. p. 176. Agronomy Abstracts, American Society of Agronomy, Madison, Wis.

Hopkins, A. A., and C. M. Taliaferro. 1996. Effect of temperature on floral initiation in switchgrass. p. 96. Agronomy Abstracts, American Society of Agronomy, Madison, Wis.

Taliaferro, C. M. 2000. Breeding seed- and vegetatively-propagated Bermuda grasses and switchgrass. p. 176. Agronomy Abstracts, American Society of Agronomy, Madison Wis.

Taliaferro, C. M., and A. A. Hopkins. 1995. Chromosome number determination and crossability of switchgrass accessions. p. 84. Agronomy Abstracts, American Society of Agronomy, Madison, Wis.

Taliaferro, C. M., and A. Parco. 2000. Inheritance of Allozyme markers in switchgrass. p. 104. Agronomy Abstracts, American Society of Agronomy, Madison Wis.

Thomason, W. E., R. W. Mullen, R. K. Teal, G. V. Johnson, C. M. Taliaferro, K. W. Freeman, and W. R. Raun. 2001. Switchgrass nutrient composition and carbon sequestration as affected by nitrogen rate. Agronomy Abstracts, American Society of Agronomy, Madison Wis.

http://www.annualmeeting2001.com/Abstracts/

Thomason, W. E., W. R. Raun, C. M. Taliaferro, S. B. Phillips, G. V. Johnson, and D. A. Cossey. 1999. Switchgrass response to harvest frequency, time, and rate of applied nitrogen. p. 256. Agronomy Abstracts, American Society of Agronomy, Madison Wis.

\section{THESES}

Parco, A. Current. 2000. Genome constitution and inheritance study in switchgrass (Panicum virgatum) using isozyme and DNA markers. 


\section{PUBLICATIONS IN DEVELOPMENT}

Das, M., C. M. Taliaferro, and R. Fuentes. Improvement potential in switchgrass populations as indicated by genetic variances for biomass yield and yield components.

Parco, A. and C. M. Taliaferro. Inheritance of allozyme markers in switchgrass, Panicum virgatum.

Taliaferro, C. M., R. Fuentes, A. A. Hopkins, and R. M. Edwards. Cytology and fertility of interploidy switchgrass, Panicum virgatum (L.) hybrids. 


\section{7-2001 PROJECT REPORT}

\section{SUMMARY}

Switchgrass research at Oklahoma State University is aimed at developing improved cultivars for the central and southern United States. Supporting research objectives include: (1) switchgrass germplasm collection, characterization, and enhancement; (2) elucidation of cytogenetic and breeding behavior; and (3) identification of best breeding procedures.

Field evaluation results to date indicate that initial (1992-1996) breeding using Restricted Recurrent Phenotypic Selection (RRPS) generated four cyclic breeding populations $\left(\mathrm{SL} \mathrm{C}_{1}, \mathrm{SU}\right.$ $\mathrm{C}_{3}, \mathrm{SU} \mathrm{C}_{1}$, and $\mathrm{NU} \mathrm{C}_{3}$ ) with significantly higher biomass yields than their respective base $\mathrm{C}_{0}$ populations. However, the magnitudes of response in these populations and the failure to achieve significant response in other populations led to a decision in 1997 to change to Genotypic Recurrent Selection (GRS).

Several experimental upland and lowland cultivars, synthesized using elite parent plants from breeding populations, have performed well in multiple environment testing. Biomass yields of the SU 92-1 synthetic exceeded the yield of Caddo in Oklahoma tests by $12 \%$. The biomass yields of NU 92-1, NU 94-2, and NU 94-1 were 21, 19, and 17\% greater, respectively, than that of $\mathrm{C}_{0}$ Pathfinder. All lowland experimental synthetics, except NL 93-2, had mean biomass yields in Oklahoma tests higher than their Alamo or Kanlow controls. Yield advantages for lowland experimental synthetics relative to controls, averaged over all tests, ranged from 2\% for SL 93-2 to $6 \%$ for SL $93-3$ and SL $92-1$ for the southern types and from -7\% in NL 93-2 to $4 \%$ in NL 94-1 for the northern types.

One cycle of GRS was completed in two lowland populations (SL 93 and NL 94) and the second cycle was initiated and will be completed in 2002. One cycle of GRS was initiated in two upland switchgrass populations, one early maturing and the other late maturing. Third-year biomass yield data of half-sib families from NL 94 in high- and low-yielding environments were determined from nurseries established in 1997. Significant sources of variation for biomass yield were attributable to cultivars, years, environments, and interactions of cultivar $\mathrm{X}$ year, and cultivar $\mathrm{X}$ environment. Highly significant $(\mathrm{P}<0.0001)$ Spearman's rank correlation coefficients indicated that in spite of the significant cultivar X year and cultivar X environment interactions for biomass yield, the relative performance of a number of cultivars was conserved over years and environments. The performance of the top cultivars in both high and low-yielding environments was very conserved. Seven of the top ten cultivars were common to both test environments. Results to date indicate that yield environment has some effect on selection response, but also indicate the potential for developing cultivars that will perform well under either high- or lowyield environmental conditions. Plants were selected from the NL 94 nursery, based on half-sib progeny performance, as parents for synthesis of three new experimental synthetic cultivars.

Mid- and high-parent heterosis values for three $F_{1}$ hybrids resulting from crosses of parent plants from three populations (NU 94, NU 93, and SL 93) were estimated for 1998, 1999, 2000, and their 3-year mean. Heterosis estimates varied among the three hybrids and varied from year to year. The NU 94 hybrid expressed the highest heterosis with mean mid- and high-parent values of $56 \%$ and 39\%, respectively. The SL 93 hybrid had mid- and high-parent values of $16 \%$ and $-5 \%$, respectively. The heterotic response was poorest in the NU 93 hybrid, which had mid- and highparent heterosis values of $-4 \%$ and $-16 \%$, respectively. The heterotic response tended to be highest in the first post-establishment year and tended to decline in following years. Estimates of 
mid- and high-parent heterosis for nine inter-ploid (4x by $8 \mathrm{x}$, or reciprocal) hybrids were also positive for some combinations based on 2-year mean biomass yields. The combined results document the presence of heterosis in switchgrass and the fact that it is specific for certain hybrid combinations. To further study combining ability and heterotic response, we selected a set of seven elite parents (three with NL background and three with SL background) based on their halfsib performance. These six clonal parents were intermated in 2001 using a partial diallel design to evaluate their general and specific combining abilities.

Switchgrass cultivars tested for 7 years (1994-2000) at Chickasha and Haskell, Oklahoma, differed significantly for biomass yields. Alamo and Kanlow have higher mean biomass production than other cultivars in the test. Yields of these two cultivars have fluctuated some with years, but high yields throughout the duration of the test demonstrate their ability to consistently perform well over time. Yields of the two cultivars ranged from about 4 tons dry biomass/acre in the poorest year to about 9 tons/acre in the better years. Cave-in-Rock, Caddo, and Late Synthetic High Yield had the lowest biomass yields among cultivars.

\section{INTRODUCTION}

To support the overall goal of developing switchgrass (Panicum virgatum L.) into a profitable bioenergy crop, the switchgrass breeding project at Oklahoma State University is charged with developing cultivars with enhanced biomass yield potential mainly for the central and southern United States. Switchgrass breeding at Oklahoma State University was initiated 1992 in four switchgrass populations designated as northern upland (NU), southern upland (SU), northern lowland (NL), and southern lowland (SL). The germplasms used to synthesize the four populations were from central and southern states, thus "northern" and "southern" distinguishes the parent materials on the basis of latitude of origin within this geographic region. The terms "upland" and "lowland" refer to ecotypes adapted to non-alluvial and alluvial soils, respectively. Evaluation of breeding methodology identified Genotypic Recurrent Selection (GRS, selection based on progeny performance) as a likely more efficient procedure compared to Restricted Recurrent Phenotypic Selection (RRPS). Accordingly, GRS replaced RRPS as the procedure of practice beginning in 1997.

Additional research was initiated concurrently with the breeding in 1992 to provide switchgrass germplasm resources and basic information needed to facilitate long-term breeding and genetic investigations. Specific supporting objectives were to: (1) assemble a comprehensive switchgrass germplasm collection and characterize individual accessions for standard cytological, agronomic, morphological and physiological traits (descriptors); (2) better characterize breeding behavior in terms of self-fertility / incompatibility and hybridization potential between ecotypic and chromosome ploidy morphs; (3) assess yield performance of cultivars and cultivar blends; and (4) assess acidity tolerance in selected populations.

\section{EVALUATION OF BREEDING MATERIALS}

\section{Descriptions of Experiments}

Field experiments providing data for this report section were planted during the period 19962001. They were intended to evaluate the performance of cyclic breeding populations and narrow base synthetics developed in the early stages of the breeding program. Cyclic breeding populations refers to populations developed by the RRPS procedure initially used. Narrow base 
synthetics refers to experimental cultivars synthesized by intercrossing a few (2 to ca 12 ) of the most elite plants identified in the respective broader genetic base RRPS populations. Both cyclic breeding populations and narrow base synthetics are simply referred to as "populations" in some parts of this report.

In 1996, upland (SU and NU) and lowland (SL and NL) populations were established in spaceplanted tests at the South Central Research Station (SCRS), Chickasha, Oklahoma, and at the Perkins Research Station (PRS), Perkins, Oklahoma. Populations included in these tests were developed from 1992 through 1995. Details of the tests are given in Table 9.

Table 9. Information on switchgrass tests planted in 1996

\begin{tabular}{|c|c|c|c|c|}
\hline & \multicolumn{4}{|c|}{ Switchgrass tests } \\
\hline & 96-1 & $96-2$ & $96-3$ & $96-4$ \\
\hline Location & $\mathrm{SCRS}^{\mathrm{a}}$ & SCRS & $\mathrm{PRS}^{\mathrm{b}}$ & PRS \\
\hline $\begin{array}{l}\text { Populations } \\
\text { Tested }\end{array}$ & SL and NL & SU and NU & SL and NL & SU and NU \\
\hline $\begin{array}{l}\text { Establishment } \\
\text { Method }\end{array}$ & $\begin{array}{l}\text { Spaced Plants; } 4 \\
\text { rows of } 12 \text { plts, } \\
2 " \text { spacing }\end{array}$ & $\begin{array}{l}\text { Spaced Plants; } 4 \\
\text { rows of } 12 \text { plts, } \\
2 \text { " spacing }\end{array}$ & $\begin{array}{l}\text { Spaced Plants; } 4 \\
\text { rows of } 12 \text { plts, } \\
2 \text { " spacing }\end{array}$ & $\begin{array}{l}\text { Spaced Plants; } 4 \text { rows } \\
\text { of } 12 \text { plts, } \\
2 \text { " spacing }\end{array}$ \\
\hline Plot size & $6 "$ X 22" & $6 "$ X 22" & $6 "$ X 22" & $6 "$ X 22" \\
\hline Date planted & $5 / 23 / 96$ & $5 / 22 / 96$ & $6 / 11 / 96$ & $6 / 10 / 96$ \\
\hline Expt. design & RCB, 4 Reps & RCB, 4 Reps & RCB, 4 Reps & RCB, 4 Reps \\
\hline Soil type & Reinach silt loam & Reinach silt loam & Teller silt loam & Teller silt loam \\
\hline Entries & Alamo & $\mathrm{SU} \mathrm{C}_{0}$ (SU C0(Caddo) $)$ & Alamo & $\mathrm{SU} \mathrm{C}_{0}$ (SU C0(Caddo) $)$ \\
\hline & $\mathrm{SL} \mathrm{C}_{\mathrm{O}}$ & $\mathrm{SU} \mathrm{C}_{1}$ & $\mathrm{SL} \mathrm{C}_{\mathrm{O}}$ & $\mathrm{SU} \mathrm{C}_{1}$ \\
\hline & $\mathrm{SL} \mathrm{C}_{1}$ & $\mathrm{SU} \mathrm{C}_{2}$ & $\mathrm{SL} \mathrm{C}_{1}$ & $\mathrm{SU} \mathrm{C}_{2}$ \\
\hline & $\mathrm{SL} \mathrm{C}_{2}$ & $\mathrm{SU} \mathrm{C}_{3}$ & $\mathrm{SL} \mathrm{C}_{2}$ & $\mathrm{SU} \mathrm{C}_{3}$ \\
\hline & SL 92-1 Syn & SU 92-1 Syn & SL 92-1 Syn & SU 92-1 Syn \\
\hline & SL 94-1 Syn & NU $\mathrm{C}_{0 \text { (Pathfinder)) }}$ & SL 94-1 Syn & $\mathrm{NU} \mathrm{C}_{0}$ (Pathfinder) \\
\hline & $\mathrm{NL} \mathrm{C}_{0}$ & $\mathrm{NU} \mathrm{C}_{1}$ & $\mathrm{NL} \mathrm{C}_{0}$ & $\mathrm{NU} \mathrm{C}_{1}$ \\
\hline & $\mathrm{NL} \mathrm{C}_{1}$ & $\mathrm{NU} \mathrm{C}_{2}$ & $\mathrm{NL} \mathrm{C}_{1}$ & $\mathrm{NU} \mathrm{C}_{2}$ \\
\hline & $\mathrm{NL} \mathrm{C}_{2}$ & $\mathrm{NU} \mathrm{C}_{3}$ & $\mathrm{NL} \mathrm{C}_{2}$ & $\mathrm{NU} \mathrm{C}_{3}$ \\
\hline & NL 92-1 Syn & NU 92-1 Syn & NL 92-1 Syn & NU 92-1 Syn \\
\hline & NL 94-1 Syn & NU 94-1 Syn & NL 94-1 Syn & NU 94-1 Syn \\
\hline & & Blackwell & & Blackwell \\
\hline & & Cave-in-Rock & & Cave-in-Rock \\
\hline Harvest dates & $10 / 13 / 99$ & 08/20/99 & $10 / 05 / 99$ & 09/29/99 \\
\hline & $10 / 22 / 98$ & $10 / 08 / 98$ & $11 / 02 / 98$ & $11 / 13 / 98$ \\
\hline & $12 / 06 / 97$ & $12 / 05 / 97$ & $11 / 06 / 97$ & $10 / 31 / 97$ \\
\hline
\end{tabular}

${ }^{a}$ SCRS $=$ South Central Research Station, Chickasha, Oklahoma.

${ }^{\mathrm{b}} \mathrm{PRS}=$ Perkins Research Station, Perkins, Oklahoma .

In 1997, we established tests of synthetic cultivars at the United States Department of Agriculture, Natural Resources Conservation Service (USDA-NRCS), Plant Materials Center (PMC), located at Booneville, Arkansas, and Manhattan, Kansas. The synthetic populations included in these tests were developed during the period 1992-1996. Details of the tests are presented in Table 10.

In 1998, test plots of SL and NL synthetics were established at the Northern Piedmont Agricultural Research and Extension Center at Orange, Virginia. Details of this test are presented in Table 11. An additional test of northern and southern lowland populations was established in 
Table 10. Information on switchgrass tests planted in 1997

\begin{tabular}{|c|c|c|c|c|}
\hline & \multicolumn{4}{|c|}{ Switchgrass tests } \\
\hline & \multirow[t]{2}{*}{$97-1$} & \multirow[t]{2}{*}{$97-2$} & $97-3$ & $97-4$ \\
\hline & & & \multicolumn{2}{|c|}{ NRCS-PMC } \\
\hline \multirow{3}{*}{$\begin{array}{l}\text { Location } \\
\text { Populations } \\
\text { Tested }\end{array}$} & $\mathrm{SCRS}^{\mathrm{a}}$ & SCRS & Booneville, Arkansas & Manhattan, Kansas \\
\hline & SL and NL & SU and NU & SL and NL & SL and NL \\
\hline & & & & \\
\hline \multirow{2}{*}{$\begin{array}{l}\text { Establishment } \\
\text { Method }\end{array}$} & Spaced Plants; 4 & Spaced Plants; 4 & Solid Seeded, 8" drill & Solid Seeded, 12" \\
\hline & $\begin{array}{l}\text { rows of } 12 \text { plants } \\
\text { spaced 2" apart }\end{array}$ & $\begin{array}{l}\text { rows of } 12 \text { plants } \\
\text { spaced 2" apart }\end{array}$ & spacing & drill spacing \\
\hline Plot size & 6" X 22" & 6" X 22" & $10 "$ X 20" & $10 "$ X 20" \\
\hline Date planted & $8 / 21 / 97$ & $8 / 30 / 97$ & 7/1/97 & 7/15/97 \\
\hline Expt. design & RCB, 4 Reps & RCB, 4 Reps & RCB, 4 Reps & RCB, 4 Reps \\
\hline Soil type & Reinach silt loam & Reinach silt loam & Leadvale silt loam & $\begin{array}{l}\text { Haynie Very fine } \\
\text { sandy loam } \\
\text { (VFSL) }\end{array}$ \\
\hline \multirow[t]{11}{*}{ Entries } & Alamo & $\mathrm{SU} \mathrm{C} \mathrm{C}_{0}$ & Alamo & Alamo \\
\hline & SL 92-1 Syn & $\mathrm{SU} \mathrm{C} \mathrm{C}_{2}$ & SL 93-1 & SL 93-1 \\
\hline & SL 93-1 Syn-1 & SU 92-1 Syn & SL 93-2 & SL 93-2 \\
\hline & SL 93-2 Syn-1 & SU 94-1 Syn-1 & SL 93-3 & SL 93-3 \\
\hline & SL 93-3 Syn-1 & Blackwell & SL 94-1 & SL 94-1 \\
\hline & SL 94-1 Syn-1 & NU $\mathrm{C}_{0 \text { (Pathfinder) }}$ & Kanlow & Kanlow \\
\hline & NL $\mathrm{C}_{0 \text { (Kanlow) }}$ & NU 94-1 Syn-1 & NL 93-1 & NL 93-1 \\
\hline & $\mathrm{NL} \mathrm{C}_{1}$ & NU 94-2 Syn-1 & NL 93-SP & NL 93-SP \\
\hline & NL 93-1 Syn-1 & Cave-in-Rock & NL 94-1 & NL 94-1 \\
\hline & NL 93-2 Syn & & Cave-in-Rock & Cave-in-Rock \\
\hline & NL 94-1 Syn-1 & & & \\
\hline \multirow[t]{2}{*}{ Harvest dates } & $10 / 12 / 99$ & 08/18/99 & $12 / 15 / 99$ & $10 / 28 / 99$ \\
\hline & $10 / 09 / 98$ & $10 / 09 / 98$ & $12 / 02 / 98$ & $10 / 21 / 98$ \\
\hline
\end{tabular}

${ }^{\mathrm{a}} \mathrm{SCRS}=$ South Central Research Station, Chickasha, Oklahoma.

1999 at the SCRS-PMC located at Coffeeville, Mississippi (Table 12). In 2000 and 2001, an upland test was established at Booneville Arkansas, and Manhattan, Kansas, respectively. Table 13 summarizes the details of those tests. All tests received approximately $80 \mathrm{lbs}$ N/acre/year applied in early spring. Phosphorus and potash were incorporated before planting at rates indicated by soil tests to meet sufficiency levels for a yield goal of 8 tons dry matter/acre.

\section{RESULTS}

1996 Space-planted Lowland Populations. Analyses of variance for the combined biomass yield data across years and locations revealed significant differences for cultivars $(\mathrm{P}<0.0001)$, locations $(\mathrm{P}<0.0001)$, years $(\mathrm{P}<0.0001)$, year $\mathrm{X}$ location $(\mathrm{P}<0.0001)$, and cultivar $\mathrm{X}$ location $(\mathrm{P}<0.0001)$. Accordingly, separate analyses were performed and reported for this test.

Table 14 summarizes the results of the analyses from Test 96-1, Chickasha. Significant differences among cultivars were detected only in $1997(\mathrm{P}=0.0019)$. $\mathrm{P}$-values for cultivars in 1998, 1999, and 2000 were $0.1992,0.6258$, and 0.7874, respectively. Analyses of variance comparing the 4-year mean for cultivars revealed significant differences among cultivars 
Table 11. Information on switchgrass tests at the Northern Piedmont Agricultural Research and Extension Center at Orange, Virginia, in 1998

\begin{tabular}{ll}
\hline Populations tested & SL and NL \\
Establishment method & Solid seeded, 8" drill spacing \\
Plot size & 7 X X" \\
Date planted & 6/24/98 \\
Expt. design & RCB, 4 Reps \\
Soil type & Clay Kaolinitic Thermic Rhodic Kandiudukts \\
Entries & Alamo \\
& SL92-1 \\
& SL 93-1 \\
& SL 93-2 \\
& SL 93-3 \\
& SL 94-1 \\
& Kanlow \\
& NL92-1 \\
& NL 93-1 \\
& NL 93-2 \\
& NL 94-1 \\
Cave-in-Rock \\
Harvest date
\end{tabular}

Table 12. Information on switchgrass tests at the NRCS-PMC at Coffeeville, Mississippi, in 1999

\begin{tabular}{ll}
\hline $\begin{array}{l}\text { Populations tested } \\
\text { Establishment method }\end{array}$ & SL and NL \\
& Solid seeded (8 lb/acre), \\
Almaco plot drill \\
Plot size & 6" X 20" \\
Date planted & 5/28/99 \\
Expt. design & RCB, 4 Reps \\
Soil type & \\
Entries & Alamo \\
& SL92-1 \\
& SL 93-1 \\
& SL 93-2 \\
& SL 93-3 \\
& SL 94-1 \\
& Kanlow \\
& NL92-1 \\
& NL 93-1 \\
& NL 93-2 \\
Harvest date & NL 94-1 \\
& $9 / 10 / 2000$ \\
\hline
\end{tabular}


Table 13. Information on switchgrass upland tests planted in 2000 and 2001

\begin{tabular}{lll}
\hline & \multicolumn{1}{c}{ 2000-1 } & \multicolumn{1}{c}{ 2001-1 } \\
\hline Location & \multicolumn{1}{c}{ NRCS-PMC } \\
$\begin{array}{l}\text { Populations } \\
\text { Tested }\end{array}$ & Booneville, Arkansas & Manhattan, Kansas \\
Establishment & Uplands & Uplands \\
Method & Solid Seeded, 8" drill & Solid Seeded, 12" drill \\
Plot size & spacing & spacing \\
Date planted & 10" X 20" & $10 "$ X 20" \\
Expt. design & & \\
Soil type & RCB, 4 Reps & RCB, 4 Reps \\
& Leadvale silt loam & Haynie Very fine \\
Entries & & sandy loam (VFSL) \\
& NU 92-1 & NU 92-1 \\
& NU 94-1 & NU 94-1 \\
& NU 94-2 & NU 94-2 \\
& SU 92-1 & SU 92-1 \\
& SU 94-1 & SU 94-1 \\
& SU 94-2 & SU 94-2 \\
& TN 104 & TN 104 \\
& Caddo & Caddo \\
& Blackwell & Blackwell \\
& Cave-in-Rock & Cave-in-Rock \\
& & \\
\hline
\end{tabular}

$(\mathrm{P}=0.0402)$ and years $(\mathrm{P}<0.0001)$. No significant cultivar $\mathrm{X}$ year interaction was detected $(\mathrm{P}=0.5667)$. Within the southern and northern lowland biotypes, SL 94-1 and NL 94-1, respectively, had the highest mean biomass yields, which were numerically but not statistically different than the other cultivars within each group.

At Perkins, cultivars differed significantly each year and for the 4-year mean (Table 15). The cultivar X year interaction was not significant $(\mathrm{P}=0.1386)$. Within the southern lowland cultivars, the 4-year mean biomass yields of SL $\mathrm{C}_{1}$ and SL $92-1$ were $45 \%$ and $35 \%$ higher, respectively, than that of Alamo. The NL 94-1 cultivar had numerically, but not statistically, higher biomass yield than other northern lowland cultivars.

Table 16 summarizes combined data from Chickasha and Perkins analyzed for each year and for the 4-year mean performance for the cultivars. There were significant differences among cultivars and among locations each year and for the 4-year mean. The cultivar X location interaction was significant only in 1999. For the mean analyses, P-values for cultivar, location, cultivar X location, year, and year $\mathrm{X}$ location were all highly significant $(\mathrm{P}<0.0001)$. The cultivar $\mathrm{X}$ year and cultivar $\mathrm{X}$ location $\mathrm{X}$ year interactions, however, were not statistically significant. Across years and locations, SL $\mathrm{C}_{1}$ and SL 92-1 had biomass yields significantly higher than Alamo. Mean biomass yields of SL $\mathrm{C}_{1}$ and SL 92-1 were 20 and 12\% higher, respectively, than Alamo. Overall, biomass yields at Chickasha were significantly higher than those at Perkins (7.65 vs. 6.2 tons/acre). Test 96-1 (Chickasha) and Test 96-3 (Perkins) had good stands of all 
Table 14. Biomass yield (tons/acre) of switchgrass cultivars in the 1996 space-planted lowland yield trial (Test 96-1) at Chickasha, Oklahoma

\begin{tabular}{|c|c|c|c|c|c|}
\hline \multirow[b]{2}{*}{ Entry } & \multicolumn{4}{|c|}{ Year } & \multirow[b]{2}{*}{ Mean } \\
\hline & 1997 & 1998 & 1999 & 2000 & \\
\hline $\begin{array}{l}\text { SL 94-1 } \\
\end{array}$ & 6.47 & 10.14 & 9.40 & 6.97 & 8.24 \\
\hline $\mathrm{SL} \mathrm{C}_{1}$ & 4.89 & 9.36 & 10.22 & 8.22 & 8.17 \\
\hline SL 92-1 & 6.47 & 8.78 & 8.56 & 6.81 & 7.65 \\
\hline $\mathrm{SL} \mathrm{C}_{2}$ & 5.43 & 8.31 & 8.94 & 7.48 & 7.54 \\
\hline $\mathrm{SL} \mathrm{C}_{0}$ & 4.60 & 10.00 & 9.43 & 6.93 & 7.74 \\
\hline Alamo & 6.21 & 9.16 & 9.71 & 7.29 & 8.09 \\
\hline NL 94-1 & 5.85 & 8.84 & 9.86 & 7.00 & 7.89 \\
\hline $\mathrm{NL} \mathrm{C}_{1}$ & 5.47 & 8.12 & 8.98 & 7.17 & 7.44 \\
\hline NL 92-1 & 5.26 & 8.16 & 8.14 & 7.41 & 7.24 \\
\hline $\mathrm{NL} \mathrm{C}_{2}$ & 5.28 & 7.42 & 8.56 & 6.76 & 7.00 \\
\hline $\mathrm{NL} \mathrm{C}_{0}$ & 4.81 & 8.50 & 8.83 & 6.34 & 7.12 \\
\hline LSD & 0.96 & 1.96 & 2.03 & 1.79 & 0.84 \\
\hline Mean & 5.52 & 8.80 & 9.15 & 7.12 & 7.65 \\
\hline C.V. & 12.05 & 15.44 & 15.40 & 17.41 & 15.76 \\
\hline $\mathrm{P}>\mathrm{F}$ for entries & 0.0019 & 0.1992 & 0.6258 & 0.7874 & 0.0402 \\
\hline $\mathrm{P}>\mathrm{F}$ for year & & & & & $<0.0001$ \\
\hline$P>F$ for entry $X$ year & & & & & 0.5667 \\
\hline
\end{tabular}

Table 15. Biomass yield (tons/acre) of switchgrass cultivars in the 1996 space-planted lowland yield trial (Test 96-3) at Perkins, Oklahoma

\begin{tabular}{lccccc}
\hline & \multicolumn{4}{c}{ Year } & Mean \\
\cline { 2 - 4 } \multicolumn{1}{c}{ Entry } & $\mathbf{1 9 9 7}$ & $\mathbf{1 9 9 8}$ & $\mathbf{1 9 9 9}$ & $\mathbf{2 0 0 0}$ & \\
\hline SL C $_{1}$ & 5.67 & 9.70 & 12.31 & 7.26 & 8.74 \\
SL 92-1 & 5.97 & 9.07 & 11.24 & 6.11 & 8.10 \\
SL C $_{2}$ & 5.47 & 6.69 & 8.59 & 4.97 & 6.43 \\
SL 94-1 & 5.64 & 7.88 & 6.22 & 3.98 & 5.93 \\
SL C & 5.04 & 6.79 & 5.72 & 3.67 & 5.30 \\
Alamo & 5.49 & 6.62 & 7.23 & 4.71 & 6.01 \\
NL 94-1 & 5.15 & 6.47 & 6.82 & 4.54 & 5.74 \\
NL 92-1 & 4.69 & 6.12 & 7.16 & 4.63 & 5.65 \\
NL C & 4.24 & 5.91 & 7.04 & 4.50 & 5.42 \\
NL C & 4.35 & 5.78 & 6.66 & 4.07 & 5.21 \\
NL C & 4.34 & 5.86 & 7.50 & 4.85 & 5.64 \\
LSD & 0.99 & 1.93 & 3.05 & 1.97 & 1.02 \\
Mean & 5.09 & 6.99 & 7.86 & 4.84 & 6.20 \\
C.V. & 13.40 & 19.09 & 26.90 & 28.10 & 23.62 \\
P $>$ F for entries & 0.0067 & 0.0016 & 0.0019 & 0.0412 & $<0.0001$ \\
P $>$ F for year & & & & & $<0.0001$ \\
P $>$ F for entry X year & & & & & 0.1386 \\
\hline
\end{tabular}


Table 16. Mean biomass yield (tons/acre) of switchgrass cultivars in the 1996 space-planted lowland yield trials at Chickasha and Perkins, Oklahoma (Tests 96-1 and 96-3)

\begin{tabular}{|c|c|c|c|c|c|}
\hline \multirow[b]{2}{*}{ Entry } & \multicolumn{4}{|c|}{ Year } & \multirow[b]{2}{*}{ Mean } \\
\hline & 1997 & 1998 & 1999 & 2000 & \\
\hline $\mathrm{SL} \mathrm{C}_{1}$ & 5.28 & 9.53 & 11.26 & 7.74 & 8.45 \\
\hline SL 92-1 & 6.22 & 8.92 & 9.90 & 6.46 & 7.87 \\
\hline SL 94-1 & 6.05 & 9.01 & 7.81 & 5.48 & 7.09 \\
\hline $\mathrm{SL} \mathrm{C}_{2}$ & 5.45 & 7.50 & 8.77 & 6.23 & 6.99 \\
\hline $\mathrm{SL} \mathrm{C}_{0}$ & 4.82 & 8.40 & 7.58 & 5.30 & 6.52 \\
\hline Alamo & 5.85 & 7.89 & 8.47 & 6.00 & 7.05 \\
\hline NL 94-1 & 5.50 & 7.65 & 8.34 & 5.77 & 6.81 \\
\hline NL 92-1 & 4.97 & 7.14 & 7.65 & 6.02 & 6.45 \\
\hline $\mathrm{NL} \mathrm{C}_{1}$ & 4.86 & 7.02 & 8.01 & 5.83 & 6.43 \\
\hline $\mathrm{NL} \mathrm{C}_{2}$ & 4.81 & 6.60 & 7.61 & 5.42 & 6.11 \\
\hline $\mathrm{NL} \mathrm{C}_{0}$ & 4.57 & 7.18 & 8.17 & 5.59 & 6.38 \\
\hline LSD & 0.67 & 1.35 & 1.80 & 1.30 & 0.66 \\
\hline Mean & 5.31 & 7.89 & 8.50 & 5.98 & 6.92 \\
\hline C.V. & 12.70 & 17.06 & 21.13 & 21.76 & 19.37 \\
\hline $\mathrm{P}>\mathrm{F}$ for entries & $<0.0001$ & 0.0004 & 0.0024 & 0.0303 & $<0.0001$ \\
\hline $\mathrm{P}>\mathrm{F}$ for location & 0.004 & $<0.0001$ & 0.0014 & $<0.0001$ & $<0.0001$ \\
\hline$P>F$ for entry $X$ location & 0.122 & 0.187 & 0.0093 & 0.5955 & $<0.0001$ \\
\hline $\mathrm{P}>\mathrm{F}$ for year & & & & & $<0.0001$ \\
\hline $\mathrm{P}>\mathrm{F}$ for year $\mathrm{X}$ location & & & & & $<0.0001$ \\
\hline $\mathrm{P}>\mathrm{F}$ for year $\mathrm{X}$ entry & & & & & 0.0576 \\
\hline $\mathrm{P}>\mathrm{F}$ for entry $\mathrm{X}$ location $\mathrm{X}$ year & & & & & 0.6677 \\
\hline Mean Chickasha & 5.52 & 8.80 & 9.15 & 7.12 & 7.65 \\
\hline Mean Perkins & 5.09 & 6.99 & 7.86 & 4.84 & 6.20 \\
\hline LSD & 0.29 & 0.57 & 0.77 & 0.56 & 0.28 \\
\hline
\end{tabular}

populations. The difference in biomass yields between locations likely resulted mainly from edaphic and precipitation differences between the locations.

1996 Space-planted Upland Populations. Analyses of variance for the data combined across the 4 years and two locations revealed significant differences for cultivars $(\mathrm{P}<0.0001)$, locations $(\mathrm{P}<0.0001)$, years $(\mathrm{P}<0.0001)$, and the cultivar $\mathrm{X}$ year $(\mathrm{P}=0.0287)$ and year $\mathrm{X}$ location $(\mathrm{P}<0.0001)$ interactions. Accordingly, separate analyses for locations and years were conducted.

Table 17 summarizes the results from the analyses for Test 96-2, Chickasha. There were significant differences among cultivars in 1997, 1998, and for the 4-year means. Analyses of variance for the 4-year mean yields indicated significant differences among cultivars $(\mathrm{P}<0.0001)$ and years $(\mathrm{P}<0.0001)$. The cultivar $\mathrm{X}$ year interaction was not significant $(\mathrm{P}=0.6161)$. Populations SU 92-1, SU $\mathrm{C}_{1}$, and $\mathrm{SU} \mathrm{C}_{3}$, respectively, yielded 15,13 , and $12 \%$ more biomass than the reference $\mathrm{SU} \mathrm{C}_{0}$ population (Caddo). Populations NU 92-1, NU $\mathrm{C}_{3}$, and NU 94-1, respectively, had 19, 16, and 14\% higher biomass yields than the reference $\mathrm{NU} \mathrm{C}_{0}$ (Pathfinder) population. 
Table 17. Biomass yield (tons/acre) of switchgrass cultivars in the 1996 space-planted upland yield trial (Test 96-2) at Chickasha, Oklahoma

\begin{tabular}{|c|c|c|c|c|c|}
\hline \multirow[b]{2}{*}{ Entry } & \multicolumn{4}{|c|}{ Year } & \multirow[b]{2}{*}{ Mean } \\
\hline & 1997 & 1998 & 1999 & 2000 & \\
\hline SU 92-1 & 5.10 & 3.90 & 5.38 & 5.11 & 4.87 \\
\hline $\mathrm{SU} \mathrm{C}_{1}$ & 4.92 & 4.50 & 4.79 & 4.98 & 4.80 \\
\hline $\mathrm{SU} \mathrm{C}_{3}$ & 4.50 & 3.68 & 5.07 & 5.70 & 4.74 \\
\hline $\mathrm{SU} \mathrm{C}_{2}$ & 3.48 & 3.48 & 4.53 & 4.71 & 4.05 \\
\hline $\mathrm{SU} \mathrm{C}_{0}$ (Caddo) & 4.46 & 3.59 & 4.65 & 4.33 & 4.25 \\
\hline NU 92-1 & 4.55 & 4.38 & 5.56 & 5.46 & 4.99 \\
\hline $\mathrm{NU} \mathrm{C}_{3}$ & 4.61 & 4.04 & 5.66 & 5.20 & 4.88 \\
\hline NU 94-1 & 4.45 & 4.46 & 5.33 & 4.89 & 4.78 \\
\hline $\mathrm{NU} \mathrm{C}_{1}$ & 4.45 & 3.43 & 4.62 & 4.42 & 4.23 \\
\hline $\mathrm{NU} \mathrm{C}_{2}$ & 2.96 & 2.80 & 4.60 & 5.26 & 3.90 \\
\hline $\mathrm{NU} \mathrm{C}_{0}$ (Pathfinder) & 3.85 & 3.51 & 4.94 & 4.54 & 4.21 \\
\hline Blackwell & 4.37 & 4.89 & 5.48 & 5.56 & 5.07 \\
\hline Cave-in-Rock & 4.48 & 2.97 & 4.36 & 4.54 & 4.09 \\
\hline LSD & 1.01 & 1.23 & 1.05 & 1.31 & 0.56 \\
\hline Mean & 4.32 & 3.82 & 5.00 & 4.98 & 4.53 \\
\hline C.V. & 16.34 & 22.50 & 14.65 & 18.36 & 17.83 \\
\hline$P>F$ for entries & 0.0114 & 0.0453 & 0.1854 & 0.4896 & $<0.0001$ \\
\hline $\mathrm{P}>\mathrm{F}$ for year & & & & & $<0.0001$ \\
\hline $\mathrm{P}>\mathrm{F}$ for entry $\mathrm{X}$ year & & & & & 0.6161 \\
\hline
\end{tabular}

Significant differences among cultivars at Perkins were detected only in 1997 (Table 18). Analyses of variance for the 4-year mean yields indicated significant differences for cultivars $(\mathrm{P}<0.0001)$, years $(\mathrm{P}<0.0001)$, and the cultivar $\mathrm{X}$ year interaction $(\mathrm{P}=0.0298)$. Populations, $\mathrm{SU} \mathrm{C}_{2}, \mathrm{SU} \mathrm{C}_{3}$, SU 92-1, and $\mathrm{SU} \mathrm{C}_{1}$, respectively, had 26, 25, 15, and 10\% higher biomass yields than the reference base population (Caddo). Populations $\mathrm{NU} \mathrm{C}_{3}, \mathrm{NU} 92-1, \mathrm{NU} \mathrm{C}_{1}, \mathrm{NU} \mathrm{C}_{2}$, and NU 94-1 had 24, 14, 14, 11, and 11\%, respectively, higher biomass yields than the reference population $\mathrm{NU} \mathrm{C}_{0}$ (Pathfinder).

Table 19 summarizes the results from the analyses for combined data from Chickasha and Perkins. Across locations, significant differences among cultivars were detected in 1997 and 1998. Significant differences between locations were observed in 3 of the 4 years. The cultivar X location interaction was not significant for any given year, but it was significant $(\mathrm{P}=0.0134)$ for the 4-year mean. Analyses of the 4-year mean yields indicated significant differences for all the sources of variation except for the cultivar X location X year interaction. Populations $\mathrm{SU} \mathrm{C}_{3}, \mathrm{SU} 92-1, \mathrm{SU} \mathrm{C}_{1}$, and $\mathrm{SU} \mathrm{C}_{2}$ had 16, 15, 12, and 5\% higher biomass yields, respectively, than did the reference population $\mathrm{SU} \mathrm{C}_{0}$ (Caddo). Populations NU 92-1, $\mathrm{NU} \mathrm{C}_{3}$, NU 94-1, and $\mathrm{NU} \mathrm{C}_{1}$ had 21, 19, 14, and 5\% higher biomass yields, respectively, than did the original $\mathrm{NU} \mathrm{C}_{0}$ (Pathfinder) population. Overall, biomass yields at Chickasha were significantly higher than those at Perkins each year, except for 1998. Test 96-2 (Chickasha) and 96-4 (Perkins) had good stands of all populations except one replicate in Test 96-4. Accordingly, data from only three replicates were used from this test. 
Table 18. Mean biomass yield (tons/acre) of switchgrass cultivars in the 1996 space-planted upland yield trial (Test 96-4) at Perkins, Oklahoma

\begin{tabular}{|c|c|c|c|c|c|}
\hline \multirow[b]{2}{*}{ Entry } & \multicolumn{4}{|c|}{ Year } & \multirow[b]{2}{*}{ Mean } \\
\hline & 1997 & 1998 & 1999 & 2000 & \\
\hline $\mathrm{SU} \mathrm{C}_{2}$ & 2.80 & 3.88 & 4.80 & 3.83 & 3.83 \\
\hline $\mathrm{SU} \mathrm{C}_{3}$ & 3.04 & 4.25 & 5.34 & 2.61 & 3.81 \\
\hline SU 92-1 & 3.60 & 3.98 & 4.46 & 2.05 & 3.52 \\
\hline $\mathrm{SU} \mathrm{C}_{1}$ & 2.48 & 3.58 & 4.84 & 2.58 & 3.37 \\
\hline $\mathrm{SU} \mathrm{C}_{0}$ (Caddo) & 2.84 & 3.48 & 3.90 & 1.97 & 3.05 \\
\hline $\mathrm{NU} \mathrm{C}_{3}$ & 3.16 & 3.80 & 4.89 & 3.23 & 3.77 \\
\hline NU 92-1 & 2.75 & 3.97 & 4.78 & 3.54 & 3.76 \\
\hline $\mathrm{NU} \mathrm{C}_{1}$ & 2.37 & 3.98 & 4.88 & 2.62 & 3.46 \\
\hline NU 94-1 & 2.87 & 3.49 & 4.61 & 2.77 & 3.44 \\
\hline $\mathrm{NU} \mathrm{C}_{2}$ & 1.49 & 3.43 & 5.32 & 3.51 & 3.44 \\
\hline NU $\mathrm{C}_{0}$ (Pathfinder) & 2.57 & 3.16 & 3.76 & 2.62 & 3.03 \\
\hline Cave-in-Rock & 2.95 & 3.28 & 5.00 & 3.44 & 3.67 \\
\hline Blackwell & 2.71 & 4.00 & 4.27 & 3.36 & 3.59 \\
\hline LSD & 0.54 & 0.88 & 1.25 & 1.37 & 0.51 \\
\hline Mean & 2.74 & 3.72 & 4.68 & 2.93 & 3.52 \\
\hline C.V. & 11.68 & 14.00 & 15.89 & 27.80 & 17.92 \\
\hline$P>F$ for entries & $<0.0001$ & 0.3363 & 0.3128 & 0.1634 & 0.0256 \\
\hline $\mathrm{P}>\mathrm{F}$ for year & & & & & $<0.0001$ \\
\hline$P>F$ for entry $X$ year & & & & & 0.0298 \\
\hline
\end{tabular}

1997 Space-planted Lowland Populations. Table 20 summarizes the results of the analyses for Test 97-1, Chickasha. Significant differences among cultivars were indicated only for 1998 $(\mathrm{P}=0.0007)$. Analyses of variance of the 3-year mean yields indicated significant differences among cultivars $(\mathrm{P}=0.0054)$ and years $(\mathrm{P}<0.0001)$. No significant cultivar $\mathrm{X}$ year interaction was detected $(\mathrm{P}=0.1652)$ indicating that the relative performance of the cultivars was conserved across years. The best performing SL cultivar (SL 94-1) had numerically, but not statistically, higher biomass yield than Alamo. Likewise, the best performing NL cultivar (NL 94-1) had numerically, but not statistically, higher biomass production than Kanlow.

1997 Space-planted Upland Populations. Table 21 summarizes the results of analyses for Test 97-2. Significant differences among cultivars were detected only in $1998(\mathrm{P}=0.0025)$. Analyses of variance of the 3-year mean yields revealed highly significant differences among cultivars $(\mathrm{P}<0.0001)$ and years $(\mathrm{P}<0.0001)$. The cultivar $\mathrm{X}$ year interaction was not significant $(\mathrm{P}=0.7290)$ indicating that the relative performance of cultivars was conserved among years. Within the SU cultivars, SU 94-1 had the highest mean biomass yield, significantly different than the mean of other cultivars including all four standard cultivars Caddo, Pathfinder, Blackwell, and Cave-in-Rock. Within the NU cultivars, NU 94-1 and NU 94-2 had significant higher biomass 
Table 19. Mean biomass yield (tons/acre) of switchgrass cultivars in the 1996 space-planted upland yield trials at Chickasha and Perkins, Oklahoma (Tests 96-2 and 96-4)

\begin{tabular}{|c|c|c|c|c|c|}
\hline \multirow[b]{2}{*}{ Entry } & \multicolumn{4}{|c|}{ Year } & \multirow[b]{2}{*}{ Mean } \\
\hline & 1997 & 1998 & 1999 & 2000 & \\
\hline$\overline{\mathrm{SU} \mathrm{C}_{3}}$ & 3.87 & 3.92 & 5.18 & 4.37 & 4.34 \\
\hline SU 92-1 & 4.46 & 3.94 & 4.99 & 3.79 & 4.29 \\
\hline $\mathrm{SU} \mathrm{C}_{1}$ & 3.87 & 4.11 & 4.81 & 3.95 & 4.19 \\
\hline $\mathrm{SU} \mathrm{C}_{2}$ & 3.19 & 3.65 & 4.64 & 4.33 & 3.95 \\
\hline $\mathrm{SU} \mathrm{C}_{0}$ (Caddo) & 3.77 & 3.54 & 4.33 & 3.32 & 3.74 \\
\hline NU 92-1 & 3.78 & 4.20 & 5.22 & 4.64 & 4.46 \\
\hline $\mathrm{NU} \mathrm{C}_{3}$ & 3.99 & 3.94 & 5.33 & 4.36 & 4.40 \\
\hline NU 94-1 & 3.76 & 4.04 & 5.02 & 3.98 & 4.20 \\
\hline $\mathrm{NU} \mathrm{C}_{1}$ & 3.56 & 3.66 & 4.73 & 3.65 & 3.90 \\
\hline $\mathrm{NU} \mathrm{C}_{2}$ & 2.33 & 3.07 & 4.91 & 4.51 & 3.71 \\
\hline NU $\mathrm{C}_{0}$ (Pathfinder) & 3.30 & 3.36 & 4.44 & 3.72 & 3.70 \\
\hline Cave-in-Rock & 3.83 & 3.10 & 4.63 & 4.08 & 3.91 \\
\hline Blackwell & 3.66 & 4.51 & 4.96 & 4.62 & 4.44 \\
\hline LSD & 0.62 & 0.79 & 0.79 & 0.94 & 0.39 \\
\hline Mean & 3.64 & 3.77 & 4.86 & 4.10 & 4.09 \\
\hline C.V. & 16.00 & 19.67 & 15.15 & 21.35 & 18.11 \\
\hline $\mathrm{P}>\mathrm{F}$ for entries & $<0.0001$ & 0.0404 & 0.3402 & 0.1236 & $<0.0001$ \\
\hline $\mathrm{P}>\mathrm{F}$ for location & $<0.0001$ & 0.5224 & 0.0464 & $<0.0001$ & $<0.0001$ \\
\hline$P>F$ for entry $X$ location & 0.6085 & 0.4078 & 0.1378 & 0.549 & 0.0134 \\
\hline $\mathrm{P}>\mathrm{F}$ for year & & & & & $<0.0001$ \\
\hline $\mathrm{P}>\mathrm{F}$ for year $\mathrm{X}$ location & & & & & $<0.0001$ \\
\hline $\mathrm{P}>\mathrm{F}$ for year $\mathrm{X}$ entry & & & & & 0.0287 \\
\hline$P>F$ for entry $X$ location $X$ year & & & & & 0.8762 \\
\hline Mean Chickasha & 4.32 & 3.82 & 5.00 & 4.98 & 4.53 \\
\hline Mean Perkins & 2.74 & 3.72 & 4.67 & 2.93 & 3.52 \\
\hline LSD & 0.25 & 0.31 & 0.31 & 0.37 & 0.15 \\
\hline
\end{tabular}

yields than their control NU $\mathrm{C}_{0}$ (Pathfinder). Cave-in-Rock and Pathfinder were consistently the lowest biomass yielding cultivars.

1997 Lowland Populations at NRCS-PMC, Booneville, Arkansas. Table 22 summarizes the results from analyses for Test 97-3, Booneville, Arkansas. Significant differences among cultivars were detected only in $1998(\mathrm{P}=0.0409)$. Analyses for the 3-year mean biomass yields indicated significant differences for cultivars $(\mathrm{P}=0.0124)$ and years $(\mathrm{P}<0.0001)$, but not for the cultivar $\mathrm{X}$ year interaction $(\mathrm{P}=0.1806)$. SL 93-1 had significantly higher mean biomass yield than did standard control Alamo. In fact, all SL cultivars tested had numerically higher mean biomass yield than Alamo. There were no significant differences among the NL cultivars, though NL 93-1 had the numerically highest mean biomass yield. 
Table 20. Biomass yield (tons/acre) of switchgrass cultivars evaluated in the 1997 space-planted lowland yield trial (Test 97-1) at Chickasha, Oklahoma

\begin{tabular}{lcccc}
\hline \multirow{2}{*}{ Entry } & \multicolumn{3}{c}{ Year } & Mean \\
\cline { 2 - 4 } & $\mathbf{1 9 9 8}$ & $\mathbf{1 9 9 9}$ & $\mathbf{2 0 0 0}$ & 6.88 \\
\hline SL 94-1 & 5.79 & 8.47 & 6.40 & 6.76 \\
SL 93-1 & 4.42 & 9.12 & 6.73 & 6.54 \\
SL 93-3 & 4.51 & 8.73 & 6.39 & 6.51 \\
SL 92-1 & 4.01 & 8.78 & 6.76 & 5.93 \\
SL 93-2 & 3.98 & 8.21 & 5.61 & 6.37 \\
Alamo & 4.05 & 8.54 & 6.53 & 6.90 \\
NL 94-1 & 4.57 & 8.82 & 7.30 & 6.51 \\
NL 93-1 & 3.77 & 8.66 & 7.08 & 5.78 \\
NL 93-2 & 3.12 & 7.59 & 6.64 & 5.56 \\
NL C 1 & 3.20 & 7.88 & 5.68 & 6.38 \\
Kanlow & 3.20 & 8.46 & 7.47 & 0.74 \\
LSD & 1.06 & 1.45 & 1.41 & 6.38 \\
Mean & 4.06 & 8.48 & 6.60 & 14.34 \\
CV & 18.14 & 11.85 & 14.83 & 0.0054 \\
P $>$ F for entry & 0.0007 & 0.659 & 0.2113 & $<.0001$ \\
P > F for year & & & & 0.1652 \\
P > F for entry X year & & & & \\
\hline
\end{tabular}

1998 Lowland Populations at the Northern Piedmont Agricultural Research and Extension Center at Orange, Virginia. This test was established in June 1998 by Dr. Dale Wolf and Dr. Dave Parrish of Virginia Polytechnic Institute. Biomass yields for cultivars are presented per year (1999-2001) and 3-year mean in Table 23. Overall mean biomass yield for 2001 was similar to year 2000, 15.9 and $15.7 \mathrm{Mg} \mathrm{ha}^{-1}$, respectively. The relative ranking of cultivar yields have fluctuated over years with some increasing while others decreased in yield rank. Particularly noticeable was the biomass yield increase for SL93-1, which went from $14.7 \mathrm{Mg} \mathrm{ha}^{-1}$ in 2000 to 21.3 Mg ha $\mathrm{Mn}^{-1}$ in 2001 . Biomass yield of SL93-3 for 2001 was significantly higher than that of control Alamo. Across years, SL93-3 continued to be the highest biomass producer. The 3-year mean for SL93-3 was significantly higher than that of controls Alamo and Kanlow.

1999 Lowland Populations at the NRCS-PMC in Coffeeville, Mississippi. Table 24

summarizes the results from analyses of Test 99-1. Mean biomass yield was significantly higher in 2001 than in 2000, 6.58 vs. 5.24, respectively. Different from 2000, significant differences (0.0094) among cultivars for biomass yield were detected in 2001. SL93-1 had the highest biomass yield mean (8.98 tons acre $\left.{ }^{-1}\right)$. Over years, no significant differences $(0.0618)$ among cultivars were detected. SL93-1 and SL94-1 had the highest numerical biomass yields. 
Table 21. Biomass yield (tons/acre) of switchgrass cultivars evaluated in the 1997 space-planted upland yield trial (Test 97-2) at Chickasha, Oklahoma

\begin{tabular}{lcccc}
\hline \multirow{2}{*}{\multicolumn{1}{c}{ Entry }} & \multicolumn{3}{c}{ Year } & \multirow{2}{*}{ Mean } \\
\cline { 2 - 3 } & $\mathbf{1 9 9 8}$ & $\mathbf{1 9 9 9}$ & $\mathbf{2 0 0 0}$ & \\
\hline SU 94-1 & 3.45 & 7.16 & 7.88 & 6.16 \\
SU 92-I & 3.25 & 7.51 & 6.40 & 5.72 \\
SU C $_{2}$ & 2.73 & 6.89 & 6.46 & 5.36 \\
SU C $_{0}$ (Caddo) & 2.84 & 6.51 & 6.22 & 5.19 \\
NU 94-1 & 2.82 & 7.80 & 7.04 & 5.89 \\
NU 94-2 & 3.27 & 7.43 & 6.86 & 5.85 \\
NU C 0 (Pathfinder) & 2.47 & 6.45 & 5.79 & 4.90 \\
Cave-in-Rock & 2.45 & 6.24 & 5.32 & 4.67 \\
Blackwell & 2.63 & 6.91 & 6.43 & 5.32 \\
LSD & 0.51 & 1.13 & 1.52 & 0.63 \\
Mean & 2.88 & 6.99 & 6.49 & 5.45 \\
CV & 12.16 & 11.06 & 16.1 & 14.25 \\
P > F for entry & 0.0025 & 0.1096 & 0.0935 & $<0.0001$ \\
P > F for year & & & & $<0.0001$ \\
P > F for entry X year & & & & 0.729 \\
\hline
\end{tabular}

Table 22. Biomass yield (tons/acre) of switchgrass lowland cultivars (Test 97-3) tested by NRCS at Booneville, Arkansas

\begin{tabular}{lcccc}
\hline \multirow{1}{*}{ Entry } & \multicolumn{3}{c}{ Year } & Mean \\
\cline { 2 - 4 } & $\mathbf{1 9 9 8}$ & $\mathbf{1 9 9 9}$ & $\mathbf{2 0 0 0}$ & 7.52 \\
SL 93-1 & 4.03 & 8.69 & 9.84 & 7.13 \\
SL 94-1 & 4.83 & 7.14 & 9.42 & 6.88 \\
SL 93-2 & 4.05 & 7.19 & 9.04 & 6.78 \\
SL 93-3 & 4.99 & 6.93 & 8.43 & 6.22 \\
Alamo & 4.53 & 6.99 & 7.15 & 7.45 \\
NL 93-1 & 5.25 & 7.07 & 10.04 & 6.61 \\
NL 93-SP & 4.52 & 5.77 & 9.55 & 6.58 \\
NL 94-1 & 5.14 & 6.79 & 7.81 & 6.53 \\
Kanlow & 4.84 & 6.28 & 8.49 & 6.13 \\
Cave-in-Rock & NA & 5.82 & 6.45 & NA \\
LSD (0.05) & 0.82 & 1.86 & 2.64 & 6.81 \\
Mean & 4.68 & 6.87 & 8.66 & 19.79 \\
CV & 11.95 & 18.69 & 21.04 & 0.0124 \\
P $>$ F entry & 0.0409 & 0.1438 & 0.1226 & $<0.0001$ \\
P > F year & & & & 0.1806 \\
P $>$ F entry X year & & & &
\end{tabular}


Table 23. Biomass yield of switchgrass lowland cultivars tested by Virginia Polytechnic and State University at Orange, Virginia

\begin{tabular}{clrccc}
\hline & & \multicolumn{4}{c}{ Yield (Mg/ha) } \\
\cline { 2 - 5 } Rank & Entry & $\mathbf{1 9 9 9}$ & $\mathbf{2 0 0 0}$ & $\mathbf{2 0 0 1}$ & Mean \\
\hline 1 & SL 93-3 & 16.3 & 18.7 & 18.8 & 17.3 \\
3 & SL 94-1 & 12.9 & 16.5 & 20.0 & 16.5 \\
4 & SL 92-1 & 12.8 & 16.0 & 18.0 & 15.6 \\
2 & SL 93-1 & 14.0 & 14.7 & 21.3 & 16.7 \\
8 & SL 93-2 & 10.4 & 16.8 & 18.2 & 15.1 \\
5 & Alamo & 12.2 & 15.6 & 14.2 & 14.0 \\
7 & NL 94-1 & 11.4 & 16.1 & 12.3 & 13.3 \\
6 & NL 92-1 & 11.2 & 15.4 & 16.4 & 14.3 \\
10 & NL 93-1 & 9.4 & 15.8 & 15.0 & 13.4 \\
11 & NL 93-2 & 9.0 & 14.8 & 13.0 & 12.3 \\
9 & Kanlow & 9.1 & 16.4 & 16.1 & 13.9 \\
12 & Cave-in-Rock & 6.7 & 11.0 & 7.9 & 8.5 \\
& MEAN & 11.3 & 15.7 & 15.9 & 14.3 \\
& LSD (0.05) & 2.2 & 3.0 & 3.7 & 3.0 \\
\hline
\end{tabular}

Table 24. Biomass yield (tons/acre) of switchgrass cultivars tested by NRCS at Coffeeville, Mississippi

\begin{tabular}{llll}
\hline \multicolumn{1}{c}{ Entry } & $\mathbf{2 0 0 0}$ & $\mathbf{2 0 0 1}$ & Mean \\
\hline SL 93-2 & $5.86 \mathrm{a}$ & $5.94 \mathrm{bc}$ & $5.90 \mathrm{~b}$ \\
SL 94-1 & $5.70 \mathrm{a}$ & $6.81 \mathrm{~b}$ & $6.25 \mathrm{ab}$ \\
SL 93-1 & $5.45 \mathrm{a}$ & $8.89 \mathrm{a}$ & $7.17 \mathrm{a}$ \\
SL 92-1 & $5.42 \mathrm{a}$ & $5.87 \mathrm{bc}$ & $5.65 \mathrm{~b}$ \\
SL 93-3 & $4.95 \mathrm{a}$ & $6.53 \mathrm{bc}$ & $5.74 \mathrm{~b}$ \\
Alamo & $5.39 \mathrm{a}$ & $6.65 \mathrm{bc}$ & $6.02 \mathrm{ab}$ \\
NL 93-1 & $5.16 \mathrm{a}$ & $6.87 \mathrm{~b}$ & $6.01 \mathrm{~b}$ \\
NL 93-2 & $5.05 \mathrm{a}$ & $6.40 \mathrm{bc}$ & $5.72 \mathrm{~b}$ \\
NL 92-1 & $4.94 \mathrm{a}$ & $6.63 \mathrm{bc}$ & $5.78 \mathrm{~b}$ \\
NL 94-1 & $4.54 \mathrm{a}$ & $6.49 \mathrm{bc}$ & $5.52 \mathrm{~b}$ \\
Kanlow & $5.24 \mathrm{a}$ & $5.27 \mathrm{c}$ & $5.26 \mathrm{~b}$ \\
LSD $(0.05)$ & 1.55 & 1.50 & 1.15 \\
Mean & 5.24 & 6.58 & 5.91 \\
\hline
\end{tabular}

\section{Discussion}

The biomass yield results provide insight into the effectiveness of the breeding procedures used in the initial stages of this project. The RRPS cyclic populations $\mathrm{SL} \mathrm{C}_{1}, \mathrm{SU} \mathrm{C}_{3}, \mathrm{SU} \mathrm{C}_{1}$, and NU $\mathrm{C}_{3}$ had significantly higher biomass yields than their respective $\mathrm{C}_{0}$ populations (Table 25). However, the cumulative data continue to support our conclusion that RRPS failed to provide consistent definitive positive increases in biomass yield. All populations developed in 1994 ( $\mathrm{SL} \mathrm{C}_{2}, \mathrm{NL} \mathrm{C}_{2}, \mathrm{SU} \mathrm{C}_{2}$, and $\mathrm{NU} \mathrm{C}_{2}$ ) had lower biomass yields (some statistically significant) than their counterpart $\mathrm{C}_{1}$ populations indicating negative genetic gains for all four $\mathrm{C}_{2}$ populations. The 
results reinforce our belief that the "fast track" RRPS breeding procedure has limited potential in switchgrass breeding because: (1) establishment year performance of individual plants is not highly predictive of subsequent years performance, and (2) the phenotypic yield performance of individual plants does not adequately predict their breeding value. Measurement of the biomass yields of individual plants one or more years beyond the establishment year may provide substantially better estimates of their true performance, and consequently may improve selection effectiveness.

Table 25. Mean performance of cyclic breeding populations relative to their base populations when averaged over different tests

\begin{tabular}{|c|c|c|c|c|}
\hline Southern lowland & Mean & $\mathrm{SL} \mathrm{C}_{0}$ & $\% \mathrm{SL} \mathrm{C}_{0}$ & Tests \\
\hline $\mathrm{SL} \mathrm{C}_{1}$ & 8.45 & 6.52 & 130 & $(96-1,96-3)$ \\
\hline $\mathrm{SL} \mathrm{C}_{2}$ & 6.99 & 6.52 & 112 & $(96-1,96-3)$ \\
\hline Northern lowland & Mean & $\mathrm{NL} \mathrm{C}$ & $\% \mathrm{NL} \mathrm{C}_{0}$ & Tests \\
\hline $\mathrm{NL} \mathrm{C}_{1}$ & 6.43 & 6.38 & 101 & $(96-1,96-3)$ \\
\hline $\mathrm{NL} \mathrm{C}_{2}$ & 6.11 & 6.38 & 96 & $(96-1,96-3)$ \\
\hline Southern upland & Mean & $\mathrm{SU} \mathrm{C}_{0}$ & $\% \mathrm{SU} \mathrm{C}_{0}$ & Tests \\
\hline $\mathrm{SU} \mathrm{C}_{3}$ & 4.34 & 3.74 & 116 & $(96-2,96-4)$ \\
\hline $\mathrm{SU} \mathrm{C}_{2}$ & 3.95 & 3.74 & 106 & $(96-2,96-4)$ \\
\hline $\mathrm{SU} \mathrm{C}_{1}$ & 4.19 & 3.74 & 112 & $(96-2,96-4)$ \\
\hline Northern upland & Mean & $\mathrm{NU} \mathrm{C}_{\mathbf{0}}$ & $\% \mathrm{NU} \mathrm{C}_{0}$ & Tests \\
\hline $\mathrm{NU} \mathrm{C}_{3}$ & 4.40 & 3.7 & 119 & $(96-2,96-4)$ \\
\hline $\mathrm{NU} \mathrm{C}_{2}$ & 3.71 & 3.7 & 100 & $(96-2,96-4)$ \\
\hline $\mathrm{NU} \mathrm{C}_{1}$ & 3.90 & 3.7 & 105 & $(96-2,96-4)$ \\
\hline
\end{tabular}

The mean performance results indicate sustained biomass yield advantage for some experimental synthetic cultivars relative to standard controls. Over years, the SU 92-1 synthetic had a mean ( 3 tests) $12 \%$ yield advantage over its base population, $\mathrm{SU} \mathrm{C}_{0}$ (Caddo). Synthetics NU 92-1, NU 94-2, and 94-1 each had mean yield increases of $21 \%, 19 \%$, and $17 \%$, respectively, over their base population (Table 26). All of our lowland experimental synthetics except for NL 93-2 had mean biomass yields higher than their respective Alamo or Kanlow controls. Yield advantages for lowland experimental synthetics over controls averaged overall tests ranged from 2\% in SL 93-2 to 6\% in SL 93-3 and SL 92-1 for the southern ecotypes and from -7\% in NL $93-2$ to $4 \%$ in NL 94-1 for the northern ecotypes (Table 20). Results of the half-sib progeny evaluations enabled selection of elite plants as parents in the synthetics. These elite parents have been matched in some cases recently in "2-clone" synthetics. The potential benefits of using only two parental plants is increased biomass yields due to favorable dominance and epistatic gene interactions, which are frequently responsible for heterosis, or "hybrid vigor."

\section{BREEDING RESEARCH}

The breeding research plan outlined in the project renewal proposal submitted March 27, 1997, was initiated in 1997 and continues to date. A description of breeding research activities and progress follows: 
Table 26. Mean performance of experimental synthetics relative to their controls when averaged over tests

\begin{tabular}{|c|c|c|c|c|}
\hline Southern lowland & Mean & Alamo mean & \% of Alamo & Tests \\
\hline SL 93-3 & 5.90 & 5.54 & 106 & $(97-1,97-3,97-4,98-1,99-1)$ \\
\hline SL 92-1 & 6.82 & 6.41 & 106 & $(96-1,96-3,97-1,98-1,99-1)$ \\
\hline SL 93-1 & 5.81 & 5.54 & 105 & $(97-1,97-3,97-4,98-1,99-1)$ \\
\hline SL 94-1 & 6.21 & 5.97 & 104 & $(96-1,96-3,97-1,97-3,97-4,98-1,99-1)$ \\
\hline SL 93-2 & 5.68 & 5.54 & 102 & $(97-1,97-3,97-4,98-1,99-1)$ \\
\hline Northern lowland & Mean & Kanlow & \% of Kanlow & Tests \\
\hline NL 94-1 & 5.88 & 5.66 & 104 & $(96-1,96-3,97-1,97-3,97-4,98-1,99-1)$ \\
\hline NL 93-1 & 5.51 & 5.37 & 103 & $(97-1,97-3,97-4,98-1,99-1)$ \\
\hline NL 93-SP & 5.19 & 5.08 & 102 & $(97-3,97-4,98-1)$ \\
\hline NL 92-1 & 6.01 & 6.00 & 100 & $(96-1,96-3,99-1)$ \\
\hline NL 93-2 & 5.38 & 5.75 & 93 & $(97-1,98-1,99-1)$ \\
\hline Southern upland & Mean & $\mathrm{SU} \mathrm{C}_{\mathbf{0}}$ & $\% \mathrm{SU} \mathrm{C}_{0}$ & Tests \\
\hline SU 94-1 & 6.16 & 5.19 & 119 & $(97-2)$ \\
\hline SU 92-1 & 5.01 & 4.47 & 112 & $(96-2,96-4,97-2)$ \\
\hline Northern upland & Mean & $\mathrm{NU} \mathrm{C}_{0}$ & $\% \mathrm{NU} \mathrm{C}_{0}$ & Tests \\
\hline NU 92-1 & 4.46 & 3.7 & 121 & $(96-2,96-4)$ \\
\hline NU 94-2 & 5.85 & 4.9 & 119 & $(97-2)$ \\
\hline NU 94-1 & 5.05 & 4.3 & 117 & $(96-2,96-4,97-2)$ \\
\hline
\end{tabular}

\section{Southern Lowland}

The SL base population was synthesized in 1993 from plants of Alamo, PMT-279, and PMT-785. Accordingly, the population is best adapted to the southern half of the targeted region of the breeding program. The SL population underwent three cycles of RRPS through 1996, at which time the breeding procedure was changed to GRS. One cycle of GRS has been completed and the second is in progress. In spring 2001, 130 half-sib families were planted in a replicated field test to assess biomass yield performance through at least 2002. The nursery was established early (April) and made exceptionally good growth through the growing season permitting harvest near season's end. Table 27 summarizes the biomass yields for each of the SL93- $\mathrm{C}_{1}$ hs families at Perkins. Significant differences were detected among families. Mean biomass yield was $1.38 \mathrm{lb} /$ plant with a range from 1.03 to $1.81 \mathrm{lb} /$ plant. Parental selections will be made after the 2002 growing season and polycrossed in 2003 to produce seed to start the next selection cycle. 
Table 27. Biomass yield of SL93-C1 half-sib families at Perkins, Oklahoma, 2001

\begin{tabular}{|c|c|c|c|c|c|c|}
\hline Population & Entry & Rep 1 & Rep 2 & Rep 3 & Rep 4 & Mean \\
\hline SL93-C1 & $16-14$ & 1.47 & 1.73 & 1.88 & 2.15 & 1.81 \\
\hline SL93-C1 & $18-08$ & 1.96 & 1.46 & 1.83 & 1.53 & 1.70 \\
\hline SL93-C1 & $29-14$ & 2.09 & 1.67 & 1.71 & 1.25 & 1.68 \\
\hline SL93-C1 & $29-29$ & 1.71 & 1.84 & 1.76 & 1.36 & 1.66 \\
\hline SL93-C1 & $30-03$ & 1.80 & 1.51 & 1.88 & 1.36 & 1.64 \\
\hline SL93-C1 & $20-14$ & 1.42 & 1.76 & 1.73 & 1.61 & 1.63 \\
\hline SL93-C1 & 09-07 & 1.64 & 1.52 & 1.65 & 1.70 & 1.63 \\
\hline SL93-C1 & $13-11$ & 1.80 & 1.55 & 1.76 & 1.40 & 1.63 \\
\hline SL93-C1 & $12-08$ & 1.64 & 1.63 & 1.73 & 1.39 & 1.60 \\
\hline SL93-C1 & $13-01$ & 1.56 & 1.51 & 1.90 & 1.42 & 1.60 \\
\hline SL93-C1 & 03-19 & 1.20 & 1.25 & 2.12 & 1.80 & 1.59 \\
\hline SL93-C1 & $15-06$ & 1.22 & 1.70 & 1.90 & 1.53 & 1.59 \\
\hline SL93-C1 & $09-30$ & 1.36 & 1.67 & 1.78 & 1.52 & 1.58 \\
\hline SL93-C1 & $26-01$ & 1.79 & 1.63 & 1.70 & 1.18 & 1.57 \\
\hline SL93-C1 & $12-26$ & 1.49 & 1.46 & 1.97 & 1.34 & 1.56 \\
\hline SL93-C1 & $22-17$ & 1.45 & 1.97 & 1.66 & 1.16 & 1.56 \\
\hline SL93-C1 & $19-26$ & 1.67 & 1.51 & 1.15 & 1.88 & 1.55 \\
\hline SL93-C1 & $22-24$ & 1.63 & 1.36 & 1.73 & 1.46 & 1.54 \\
\hline SL93-C1 & $07-27$ & 1.72 & 1.79 & 1.21 & 1.45 & 1.54 \\
\hline SL93-C1 & $19-18$ & 1.37 & 1.73 & 1.56 & 1.49 & 1.54 \\
\hline SL93-C1 & $08-14$ & 1.49 & 1.67 & 1.45 & 1.52 & 1.53 \\
\hline SL93-C1 & $24-10$ & 1.53 & 1.75 & 1.42 & 1.42 & 1.53 \\
\hline SL93-C1 & $19-07$ & 1.26 & 1.55 & 1.58 & 1.70 & 1.52 \\
\hline SL93-C1 & $27-07$ & 1.75 & 1.46 & 1.74 & 1.13 & 1.52 \\
\hline SL93-C1 & $24-19$ & 1.51 & 1.60 & 1.46 & 1.50 & 1.52 \\
\hline SL93-C1 & $08-20$ & 1.47 & 1.43 & 1.60 & 1.53 & 1.51 \\
\hline SL93-C1 & $16-13$ & 1.77 & 1.36 & 1.39 & 1.49 & 1.50 \\
\hline SL93-C1 & $20-07$ & 1.51 & 1.67 & 1.43 & 1.37 & 1.50 \\
\hline SL93-C1 & $23-17$ & 1.61 & 1.58 & 1.39 & 1.40 & 1.50 \\
\hline SL93-C1 & $17-27$ & 1.58 & 1.36 & 1.46 & 1.55 & 1.49 \\
\hline SL93-C1 & $21-27$ & 1.41 & 1.39 & 1.85 & 1.30 & 1.48 \\
\hline SL93-C1 & $18-03$ & 1.55 & 1.07 & 2.10 & 1.21 & 1.48 \\
\hline SL93-C1 & $30-07$ & 1.19 & 1.58 & 1.85 & 1.31 & 1.48 \\
\hline SL93-C1 & $12-28$ & 1.30 & 1.49 & 1.65 & 1.46 & 1.48 \\
\hline SL93-C1 & $07-03$ & 1.28 & 1.48 & 1.46 & 1.68 & 1.48 \\
\hline SL93-C1 & $16-08$ & 1.67 & 1.34 & 1.39 & 1.49 & 1.47 \\
\hline SL93-C1 & $14-02$ & 1.11 & 1.61 & 1.34 & 1.82 & 1.47 \\
\hline SL93-C1 & $22-12$ & 1.66 & 1.40 & 1.64 & 1.18 & 1.47 \\
\hline SL93-C1 & $26-07$ & 0.90 & 2.06 & 1.70 & 1.21 & 1.47 \\
\hline SL93-C1 & $18-26$ & 1.83 & 1.52 & 1.33 & 1.16 & 1.46 \\
\hline SL93-C1 & $03-11$ & 1.42 & 2.08 & 1.30 & 1.04 & 1.46 \\
\hline SL93-C1 & $17-16$ & 1.40 & 1.48 & 1.43 & 1.52 & 1.46 \\
\hline SL93-C1 & 19-09 & 1.42 & 1.19 & 1.66 & 1.53 & 1.45 \\
\hline SL93-C1 & 04-19 & 1.46 & 1.42 & 1.61 & 1.28 & 1.44 \\
\hline
\end{tabular}


Table 27. (Continued)

\begin{tabular}{|c|c|c|c|c|c|c|}
\hline Population & Entry & Rep 1 & Rep 2 & Rep 3 & Rep 4 & Mean \\
\hline SL93-C1 & $21-17$ & 1.20 & 1.31 & 1.72 & 1.53 & 1.44 \\
\hline SL93-C1 & $26-05$ & 1.56 & 1.58 & 1.70 & 0.89 & 1.44 \\
\hline SL93-C1 & $23-32$ & 1.36 & 1.60 & 1.22 & 1.56 & 1.44 \\
\hline SL93-C1 & $30-31$ & 1.42 & 1.24 & 1.56 & 1.50 & 1.43 \\
\hline SL93-C1 & $23-15$ & 1.23 & 1.72 & 1.57 & 1.19 & 1.43 \\
\hline SL93-C1 & $02-28$ & 1.23 & 1.37 & 1.87 & 1.22 & 1.42 \\
\hline SL93-C1 & $08-17$ & 1.23 & 1.48 & 1.59 & 1.39 & 1.42 \\
\hline SL93-C1 & $12-14$ & 1.53 & 1.42 & 1.45 & 1.28 & 1.42 \\
\hline SL93-C1 & $19-15$ & 1.61 & 1.54 & 1.46 & 1.03 & 1.41 \\
\hline SL93-C1 & $29-18$ & 1.74 & 0.92 & 1.18 & 1.80 & 1.41 \\
\hline SL93-C1 & $04-27$ & 1.53 & 1.82 & 1.22 & 1.06 & 1.41 \\
\hline SL93-C1 & $21-10$ & 1.52 & 1.82 & 1.31 & 0.98 & 1.41 \\
\hline SL93-C1 & 04-05 & 1.77 & 1.51 & 1.21 & 1.15 & 1.41 \\
\hline SL93-C1 & $28-33$ & 1.44 & 1.18 & 1.45 & 1.56 & 1.41 \\
\hline SL93-C1 & $26-19$ & 1.50 & 1.48 & 1.21 & 1.43 & 1.40 \\
\hline SL93-C1 & $13-05$ & 1.64 & 1.28 & 1.43 & 1.25 & 1.40 \\
\hline SL93-C1 & $24-13$ & 1.14 & 1.21 & 1.84 & 1.42 & 1.40 \\
\hline SL93-C1 & $08-26$ & 1.42 & 1.66 & 1.45 & 1.06 & 1.40 \\
\hline SL93-C1 & $02-11$ & 1.33 & 1.52 & 1.37 & 1.36 & 1.39 \\
\hline SL93-C1 & $10-15$ & 1.06 & 1.39 & 1.67 & 1.43 & 1.39 \\
\hline SL93-C1 & $23-19$ & 1.53 & 1.22 & 1.21 & 1.58 & 1.38 \\
\hline SL93-C1 & $18-01$ & 1.20 & 1.16 & 1.82 & 1.34 & 1.38 \\
\hline SL93-C1 & $01-16$ & 1.42 & 1.07 & 1.73 & 1.28 & 1.38 \\
\hline SL93-C1 & $17-03$ & 1.28 & 1.69 & 1.52 & 0.98 & 1.37 \\
\hline SL93-C1 & $13-14$ & 1.22 & 1.69 & 1.55 & 0.97 & 1.36 \\
\hline SL93-C1 & $23-12$ & 1.71 & 1.13 & 1.79 & 0.79 & 1.35 \\
\hline SL93-C1 & $29-12$ & 1.30 & 1.36 & 1.76 & 0.98 & 1.35 \\
\hline SL93-C1 & $06-07$ & 1.43 & 1.45 & 1.27 & 1.25 & 1.35 \\
\hline SL93-C1 & $11-12$ & 1.33 & 1.27 & 1.54 & 1.25 & 1.35 \\
\hline SL93-C1 & $26-28$ & 1.22 & 1.22 & 1.50 & 1.43 & 1.34 \\
\hline SL93-C1 & $14-20$ & 1.26 & 1.54 & 1.36 & 1.21 & 1.34 \\
\hline SL93-C1 & $26-30$ & 1.66 & 1.15 & 1.15 & 1.40 & 1.34 \\
\hline SL93-C1 & 09-19 & 1.42 & 1.55 & 1.24 & 1.12 & 1.33 \\
\hline SL93-C1 & 09-05 & 0.96 & 1.63 & 1.39 & 1.34 & 1.33 \\
\hline SL93-C1 & $19-29$ & 1.15 & 1.24 & 1.76 & 1.15 & 1.32 \\
\hline SL93-C1 & $11-01$ & 1.18 & 1.48 & 1.73 & 0.91 & 1.32 \\
\hline SL93-C1 & $28-08$ & 1.23 & 1.64 & 1.33 & 1.06 & 1.31 \\
\hline SL93-C1 & $18-23$ & 1.39 & 1.45 & 0.92 & 1.49 & 1.31 \\
\hline SL93-C1 & $05-27$ & 1.36 & 1.27 & 1.45 & 1.16 & 1.31 \\
\hline SL93-C1 & $12-09$ & 1.15 & 1.54 & 1.46 & 1.06 & 1.30 \\
\hline SL93-C1 & $05-22$ & 1.37 & 1.46 & 1.15 & 1.22 & 1.30 \\
\hline SL93-C1 & $10-02$ & 1.36 & 1.30 & 1.37 & 1.18 & 1.30 \\
\hline SL93-C1 & $27-17$ & 1.33 & 1.28 & 1.33 & 1.27 & 1.30 \\
\hline SL93-C1 & $20-12$ & 1.41 & 1.31 & 1.46 & 1.01 & 1.30 \\
\hline SL93-C1 & $05-16$ & 1.15 & 1.57 & 1.34 & 1.13 & 1.30 \\
\hline
\end{tabular}


Table 27. (Continued)

\begin{tabular}{|c|c|c|c|c|c|c|}
\hline Population & Entry & Rep 1 & Rep 2 & Rep 3 & Rep 4 & Mean \\
\hline SL93-C1 & 23-04 & 1.82 & 1.21 & 1.10 & 1.06 & 1.30 \\
\hline SL93-C1 & $05-25$ & 1.20 & 1.30 & 1.40 & 1.28 & 1.29 \\
\hline SL93-C1 & $16-01$ & 1.27 & 1.43 & 1.39 & 1.07 & 1.29 \\
\hline SL93-C1 & $22-07$ & 1.25 & 1.36 & 1.43 & 1.12 & 1.29 \\
\hline SL93-C1 & $13-22$ & 1.27 & 1.21 & 1.34 & 1.30 & 1.28 \\
\hline SL93-C1 & $20-09$ & 1.52 & 0.69 & 1.48 & 1.42 & 1.28 \\
\hline SL93-C1 & $02-22$ & 1.45 & 1.34 & 0.87 & 1.43 & 1.27 \\
\hline SL93-C1 & $29-11$ & 0.96 & 1.18 & 1.67 & 1.27 & 1.27 \\
\hline SL93-C1 & $06-20$ & 1.49 & 0.93 & 1.22 & 1.43 & 1.27 \\
\hline SL93-C1 & $20-31$ & 1.04 & 1.22 & 1.40 & 1.40 & 1.27 \\
\hline SL93-C1 & $05-08$ & 1.45 & 0.81 & 1.52 & 1.25 & 1.26 \\
\hline SL93-C1 & 09-17 & 1.17 & 1.18 & 1.40 & 1.28 & 1.26 \\
\hline SL93-C1 & $21-14$ & 1.25 & 1.33 & 0.93 & 1.49 & 1.25 \\
\hline SL93-C1 & $23-08$ & 1.25 & 1.37 & 1.30 & 1.07 & 1.25 \\
\hline SL93-C1 & $08-10$ & 1.31 & 1.43 & 1.31 & 0.92 & 1.24 \\
\hline SL93-C1 & $15-17$ & 1.60 & 1.21 & 0.92 & 1.24 & 1.24 \\
\hline SL93-C1 & $20-10$ & 1.53 & 1.28 & 1.28 & 0.86 & 1.24 \\
\hline SL93-C1 & $06-31$ & 1.33 & 1.28 & 1.22 & 1.12 & 1.24 \\
\hline SL93-C1 & 08-12 & 0.88 & 1.58 & 1.28 & 1.19 & 1.24 \\
\hline SL93-C1 & $12-13$ & 1.31 & 1.33 & 1.01 & 1.28 & 1.23 \\
\hline SL93-C1 & $10-29$ & 1.14 & 1.48 & 1.49 & 0.82 & 1.23 \\
\hline SL93-C1 & $29-17$ & 1.23 & 1.11 & 1.49 & 1.09 & 1.23 \\
\hline SL93-C1 & $29-06$ & 1.77 & 0.86 & 1.13 & 1.16 & 1.23 \\
\hline SL93-C1 & $30-10$ & 1.23 & 1.42 & 1.05 & 1.21 & 1.23 \\
\hline SL93-C1 & $30-16$ & 1.14 & 1.22 & 1.57 & 0.97 & 1.22 \\
\hline SL93-C1 & $15-04$ & 1.07 & 1.64 & 1.01 & 1.10 & 1.21 \\
\hline SL93-C1 & $28-18$ & 0.85 & 1.05 & 1.70 & 1.21 & 1.20 \\
\hline SL93-C1 & $05-31$ & 1.42 & 1.05 & 0.89 & 1.43 & 1.20 \\
\hline SL93-C1 & $30-01$ & 1.11 & 1.16 & 1.36 & 1.15 & 1.19 \\
\hline SL93-C1 & $01-22$ & 1.03 & 1.43 & 1.19 & 1.12 & 1.19 \\
\hline SL93-C1 & $06-14$ & 1.20 & 1.30 & 1.19 & 1.03 & 1.18 \\
\hline SL93-C1 & $11-08$ & 1.13 & 1.42 & 1.25 & 0.91 & 1.18 \\
\hline SL93-C1 & 04-06 & 0.86 & 1.49 & 1.28 & 1.06 & 1.17 \\
\hline SL93-C1 & 04-13 & 1.25 & 1.40 & 0.97 & 1.06 & 1.17 \\
\hline SL93-C1 & $13-20$ & 0.96 & 1.11 & 1.37 & 1.12 & 1.14 \\
\hline SL93-C1 & 03-15 & 1.17 & 1.22 & 1.07 & 0.88 & 1.08 \\
\hline SL93-C1 & $29-21$ & 1.28 & 1.10 & 0.72 & 1.22 & 1.08 \\
\hline SL93-C1 & $17-10$ & 1.15 & 1.13 & 1.10 & 0.88 & 1.07 \\
\hline SL93-C1 & $22-11$ & 0.71 & 1.45 & 1.24 & 0.80 & 1.05 \\
\hline SL93-C1 & 09-31 & 1.19 & 1.16 & 1.33 & 0.51 & 1.04 \\
\hline SL93-C1 & $28-06$ & 1.09 & 1.25 & 0.89 & 0.88 & 1.03 \\
\hline
\end{tabular}




\section{Northern Lowland}

The NL base population (NL $\mathrm{C}_{0}$ ) was synthesized in 1993 using plants from the Kanlow and Pangburn switchgrass cultivars. Accordingly, it has adaptation features needed for the northern half of the target region of this breeding effort. Three cycles of RRPS were completed in this population from 1994 through 1996. In 1997, we adopted GRS and also initiated research in the NL population to assess the influence of biomass yield environment on plant selection. The rationale for, and goals of, this research were previously discussed.

One cycle of GRS has been completed in the NL population and a second will be completed in 2002. The procedure being used in this population includes the evaluation of half-sib progeny plants under low- and high-yield environments. We started in 1997 with a base population (NL94 $\mathrm{C}_{0}$ ) comprising 65 plants from the NL 94 selection nursery and evaluated clonal sets of their half-sib progenies under a high-yield environment (HYE) and a low-yield environment (LYE). The HYE was achieved by growing on a fertile soil, annual application of fertilizer (71 $\mathrm{kg} \mathrm{N} \mathrm{ha}^{-1} \mathrm{yr}^{-1}+\mathrm{P}$ and $\mathrm{K}$ as indicated by soil test), and irrigation to maintain growth during drought periods. The LYE utilized a less productive soil, no supplemental fertilizer, and no irrigation. Parent plants selected on the basis of the half-sib performance were intercrossed in 1999 to produce new cyclic populations designated NL94-HYE $C_{1}$ and NL94-LYE $C_{1}$. Selection nurseries (1020 plants) of each were established, and half-sib seed of 240 plants harvested in year 2000. In spring 2001, 130 half-sib families (65 each from the NL94-HYE $\mathrm{C}_{1}$ and NL94-LYE $\mathrm{C}_{1}$ ) were planted in low- and high-yield environments for performance testing. Biomass yields were measured in 2001 and will again be measured in 2002. The 2-year data will be used to test the hypothesis that the mean biomass yield of half-sib families from the NL94 HYE $\mathrm{C}_{1}$ is equal to that of half-sib families from the NL94-LYE $\mathrm{C}_{1}$. If the hypothesis is accepted, a single new cyclic population (NL94 $\mathrm{C}_{2}$ ) will be generated based on half-sib performance data from each of the $\mathrm{C}_{1}$ tests. The HYE and LYE populations will be advanced separately if their mean yield performance differs and/or if there are significant interactions with environment. Although DOE funding has ceased, the effort will continue and intercrossing of selected parent plants will be carried out in 2003 to produce seed for the third selection cycle that will be completed by 2007 .

Biomass data were obtained at the end of the 2001 growing season from the nursery located in the HYE. Seedlings were planted early in the season and developed sufficiently to justify harvesting the first year. Plants in the LYE were planted early but did not reach a developmental stage justifying harvesting. Table 28 summarizes the biomass data for each of the $\mathrm{HYE}-\mathrm{C}_{1}$ and LYE- $\mathrm{C}_{1}$ hs families in the HYE test. Analyses of data revealed no significant differences among cultivars in the HYE test. Mean biomass yield for all families in the HYE was $1.51 \mathrm{lb} /$ plant with a range of 0.96 to $2.22 \mathrm{lb} /$ plant. Separate analyses of data for families from $\mathrm{HYE}-\mathrm{C}_{1}$ and from LYE- $\mathrm{C}_{1}$ revealed similarities between them. Mean biomass yield of $\mathrm{HYE}-\mathrm{C}_{1}$ families was $1.47 \mathrm{lb} /$ plant with a range of 0.96 to $2.22 \mathrm{lb} /$ plant. Mean biomass yield of $L Y E-C_{1}$ families was $1.54 \mathrm{lb} /$ plant with a range of 1.04 to $1.97 \mathrm{lb} /$ plant. The difference between the $\mathrm{HYE} \mathrm{C}_{1}$ and LYE- $\mathrm{C}_{1}$ means was not significant $(\mathrm{P}>0.05)$.

\section{Early- and Late-Maturing Southern-Northern Upland Populations}

Two populations that we designated as southern upland (SU) and northern upland (NU) were synthesized in 1993. The SU population was formed from Caddo, Blackwell, and other accessions from Kansas, Oklahoma, and Texas. Plants of NE-28, Cave-in-Rock, and Pathfinder were intercrossed to form the NU population. Three cycles of RRPS were completed in the SU and NU populations through 1996. Beginning in 1997, we merged the two populations into 
Table 28. Biomass yield of HYE-C1 and LYE-C1 half-sib families grown in a high-yield environment

\begin{tabular}{cccccc}
\hline Family & Rep 1 & Rep 2 & Rep 3 & Rep 4 & Mean \\
\hline HYE16-03 & 2.29 & 2.16 & 2.38 & 2.04 & 2.22 \\
HYE21-08 & 1.69 & 1.64 & 2.54 & 2.00 & 1.97 \\
LYE09-25 & 2.20 & 1.76 & 2.14 & 1.77 & 1.96 \\
LYE11-31 & 2.55 & 1.68 & 1.89 & 1.67 & 1.95 \\
LYE27-24 & 2.33 & 1.64 & 2.12 & 1.65 & 1.94 \\
LYE29-31 & 2.21 & 1.92 & 2.00 & 1.51 & 1.91 \\
HYE32-11 & 2.60 & 2.39 & 0.89 & 1.63 & 1.88 \\
LYE04-10 & 2.03 & 2.32 & 1.29 & 1.74 & 1.84 \\
HYE41-06 & 1.78 & 1.36 & 1.89 & 2.28 & 1.83 \\
LYE14-16 & 2.38 & 1.63 & 1.06 & 2.23 & 1.82 \\
HYE36-09 & 1.71 & 1.73 & 2.12 & 1.65 & 1.81 \\
LYE25-09 & 1.44 & 1.88 & 2.06 & 1.78 & 1.79 \\
HYE26-07 & 2.22 & 1.65 & 1.25 & 2.00 & 1.78 \\
LYE10-09 & 1.83 & 1.76 & 1.50 & 2.01 & 1.78 \\
LYE04-32 & 0.97 & 1.63 & 2.44 & 2.05 & 1.77 \\
LYE08-23 & 1.86 & 1.69 & 1.80 & 1.71 & 1.77 \\
LYE17-30 & 1.29 & 1.81 & 1.38 & 2.57 & 1.76 \\
HYE11-06 & 1.78 & 2.08 & 2.08 & 1.06 & 1.75 \\
LYE20-16 & 1.82 & 1.38 & 1.87 & 1.85 & 1.73 \\
LYE05-32 & 1.52 & 1.65 & 2.14 & 1.61 & 1.73 \\
HYE18-09 & 1.67 & 1.60 & 1.50 & 2.13 & 1.73 \\
LYE24-12 & 2.05 & 1.81 & 1.42 & 1.61 & 1.73 \\
LYE26-14 & 1.69 & 1.89 & 1.36 & 1.90 & 1.71 \\
HYE21-03 & 1.96 & 1.63 & 1.61 & 1.58 & 1.70 \\
LYE11-07 & 1.91 & 1.96 & 1.22 & 1.64 & 1.68 \\
LYE26-34 & 1.19 & 1.81 & 1.85 & 1.85 & 1.68 \\
HYE09-02 & 1.39 & 1.65 & 1.96 & 1.71 & 1.68 \\
LYE12-13 & 2.22 & 1.69 & 1.28 & 1.50 & 1.67 \\
HYE22-06 & 1.79 & 1.73 & 2.19 & 0.96 & 1.67 \\
HYE36-12 & 1.83 & 1.29 & 1.40 & 2.07 & 1.65 \\
LYE30-22 & 1.41 & 2.10 & 1.68 & 1.38 & 1.64 \\
LYE26-09 & 1.01 & 1.89 & 1.67 & 1.98 & 1.64 \\
HYE39-10 & 0.82 & 1.69 & 1.87 & 2.15 & 1.63 \\
LYE19-10 & 2.23 & 1.20 & 1.53 & 1.56 & 1.63 \\
LYE17-32 & 2.10 & 1.83 & 1.56 & 0.98 & 1.62 \\
LYE12-33 & 1.55 & 1.71 & 1.88 & 1.33 & 1.62 \\
HYE56-01 & 1.82 & 1.40 & 1.72 & 1.53 & 1.61 \\
HYE10-10 & 1.57 & 1.57 & 1.36 & 1.95 & 1.61 \\
HYE30-02 & 1.71 & 1.53 & 1.73 & 1.40 & 1.59 \\
LYE20-24 & 2.27 & 1.01 & 1.67 & 1.43 & 1.59 \\
LYE22-14 & 1.11 & 1.92 & 1.40 & 1.94 & 1.59 \\
HYE33-10 & 1.15 & 1.91 & 1.21 & 2.07 & 1.58 \\
LYE26-29 & 1.83 & 1.60 & 1.75 & 1.16 & 1.58 \\
LYE25-24 & 1.59 & 1.16 & 1.97 & 1.60 & 1.58
\end{tabular}


Table 28. (Continued)

\begin{tabular}{cccccc}
\hline Family & Rep 1 & Rep 2 & Rep 3 & Rep 4 & Mean \\
\hline LYE15-06 & 2.37 & 0.87 & 0.97 & 2.11 & 1.58 \\
HYE18-06 & 1.62 & 1.45 & 1.28 & 1.97 & 1.58 \\
HYE06-02 & 1.37 & 1.80 & 1.60 & 1.53 & 1.57 \\
LYE12-26 & 1.44 & 0.85 & 2.20 & 1.80 & 1.57 \\
HYE30-09 & 2.26 & 2.18 & 0.42 & 1.43 & 1.57 \\
LYE29-21 & 1.44 & 0.70 & 2.10 & 2.03 & 1.56 \\
HYE11-08 & 1.03 & 1.68 & 1.77 & 1.74 & 1.56 \\
LYE18-27 & 1.10 & 1.79 & 1.65 & 1.67 & 1.55 \\
HYE15-08 & 1.25 & 1.17 & 1.65 & 2.10 & 1.54 \\
HYE13-07 & 1.70 & 1.09 & 2.39 & 0.98 & 1.54 \\
HYE23-06 & 1.48 & 1.73 & 1.54 & 1.37 & 1.53 \\
HYE16-07 & 1.69 & 1.13 & 1.13 & 2.17 & 1.53 \\
LYE09-24 & 1.31 & 0.99 & 1.91 & 1.90 & 1.53 \\
LYE28-10 & 1.78 & 2.02 & 1.38 & 0.93 & 1.53 \\
HYE25-10 & 1.33 & 1.28 & 1.72 & 1.77 & 1.52 \\
HYE30-01 & 1.50 & 1.22 & 1.71 & 1.65 & 1.52 \\
LYE23-05 & 1.58 & 1.75 & 1.34 & 1.41 & 1.52 \\
HYE21-04 & 1.28 & 1.11 & 1.53 & 2.10 & 1.51 \\
HYE17-07 & 1.59 & 1.59 & 1.09 & 1.74 & 1.50 \\
HYE57-02 & 1.50 & 1.76 & 1.34 & 1.40 & 1.50 \\
LYE04-30 & 1.55 & 1.49 & 1.41 & 1.51 & 1.49 \\
LYE08-13 & 1.27 & 1.59 & 1.32 & 1.80 & 1.49 \\
HYE18-08 & 1.42 & 1.14 & 1.72 & 1.67 & 1.49 \\
LYE20-18 & 1.41 & 1.22 & 1.01 & 2.31 & 1.49 \\
LYE28-29 & 1.63 & 1.64 & 1.89 & 0.77 & 1.48 \\
HYE38-11 & 1.61 & 1.45 & 1.25 & 1.63 & 1.48 \\
HYE35-09 & 2.08 & 1.06 & 1.07 & 1.71 & 1.48 \\
LYE10-28 & 1.50 & 1.46 & 1.33 & 1.63 & 1.48 \\
LYE28-20 & 1.80 & 0.82 & 1.53 & 1.77 & 1.48 \\
HYE30-12 & 2.08 & 1.71 & 0.08 & 2.01 & 1.47 \\
LYE25-01 & 0.86 & 1.25 & 1.49 & 2.27 & 1.47 \\
LYE17-26 & 1.63 & 1.71 & 1.30 & 1.23 & 1.47 \\
LYE11-15 & 1.33 & 1.85 & 1.68 & 0.97 & 1.46 \\
HYE41-12 & 1.12 & 1.46 & 1.53 & 1.68 & 1.45 \\
HYE49-04 & 1.45 & 0.51 & 1.46 & 2.35 & 1.44 \\
LYE12-27 & 1.80 & 1.33 & 0.77 & 1.81 & 1.43 \\
LYE21-28 & 1.62 & 2.10 & 1.52 & 0.47 & 1.43 \\
LYE11-16 & 1.62 & 1.54 & 1.57 & 0.96 & 1.42 \\
HYE29-01 & 1.33 & 1.20 & 1.50 & 1.65 & 1.42 \\
LYE03-05 & 1.24 & 0.42 & 2.26 & 1.77 & 1.42 \\
HYE11-02 & 1.45 & 1.45 & 1.37 & 1.40 & 1.42 \\
HYE24-09 & 0.95 & 1.37 & 1.96 & 1.38 & 1.42 \\
LYE10-22 & 2.18 & 1.49 & 0.50 & 1.48 & 1.41 \\
LYE23-32 & 1.91 & 1.09 & 1.42 & 1.23 & 1.41 \\
LYE30-33 & 1.92 & 1.33 & 1.46 & 0.93 & 1.41
\end{tabular}


Table 28. (Continued)

\begin{tabular}{|c|c|c|c|c|c|}
\hline Family & Rep 1 & Rep 2 & Rep 3 & Rep 4 & Mean \\
\hline LYE06-05 & 1.59 & 1.83 & 1.29 & 0.93 & 1.41 \\
\hline HYE11-09 & 1.84 & 0.89 & 1.41 & 1.50 & 1.41 \\
\hline LYE29-25 & 2.03 & 1.21 & 0.82 & 1.54 & 1.40 \\
\hline LYE05-15 & 1.99 & 1.71 & 0.86 & 1.04 & 1.40 \\
\hline HYE34-06 & 1.55 & 1.01 & 1.29 & 1.74 & 1.40 \\
\hline HYE21-05 & 1.42 & 1.10 & 1.59 & 1.47 & 1.40 \\
\hline HYE15-05 & 1.41 & 0.87 & 1.48 & 1.77 & 1.38 \\
\hline HYE44-08 & 1.54 & 0.98 & 1.81 & 1.17 & 1.38 \\
\hline HYE37-06 & 1.88 & 1.69 & 1.36 & 0.57 & 1.38 \\
\hline LYE13-15 & 1.62 & 1.30 & 1.33 & 1.24 & 1.37 \\
\hline HYE46-01 & 1.54 & 1.53 & 1.69 & 0.73 & 1.37 \\
\hline HYE30-07 & 1.32 & 0.83 & 1.32 & 1.98 & 1.36 \\
\hline HYE25-04 & 0.89 & 1.17 & 1.91 & 1.44 & 1.35 \\
\hline HYE31-10 & 1.36 & 1.33 & 1.01 & 1.63 & 1.33 \\
\hline LYE23-34 & 1.50 & 0.74 & 1.96 & 1.10 & 1.33 \\
\hline HYE52-06 & 1.50 & 1.22 & 1.07 & 1.48 & 1.32 \\
\hline HYE26-10 & 1.41 & 1.13 & 1.56 & 1.14 & 1.31 \\
\hline LYE24-29 & 0.98 & 1.54 & 1.54 & 1.16 & 1.31 \\
\hline LYE24-28 & 1.07 & 1.73 & 1.26 & 1.16 & 1.31 \\
\hline HYE51-02 & 1.11 & 1.73 & 1.18 & 1.18 & 1.30 \\
\hline HYE08-05 & 1.44 & 1.05 & 1.21 & 1.50 & 1.30 \\
\hline LYE20-05 & 1.41 & 0.81 & 1.42 & 1.48 & 1.28 \\
\hline LYE25-34 & 2.18 & 1.09 & 1.24 & 0.61 & 1.28 \\
\hline HYE02-07 & 1.78 & 0.73 & 0.87 & 1.74 & 1.28 \\
\hline LYE19-06 & 1.75 & 1.28 & 0.82 & 1.26 & 1.28 \\
\hline HYE31-06 & 1.44 & 1.45 & 1.18 & 1.01 & 1.27 \\
\hline LYE26-08 & 1.06 & 1.20 & 0.98 & 1.84 & 1.27 \\
\hline HYE16-01 & 1.24 & 1.42 & 1.25 & 1.08 & 1.25 \\
\hline HYE14-02 & 0.95 & 1.60 & 1.24 & 1.17 & 1.24 \\
\hline HYE26-06 & 1.24 & 1.32 & 1.02 & 1.31 & 1.22 \\
\hline LYE13-27 & 1.42 & 1.28 & 1.18 & 1.00 & 1.22 \\
\hline HYE09-06 & 1.41 & 1.24 & 0.85 & 1.33 & 1.21 \\
\hline LYE09-20 & 1.06 & 1.38 & 1.36 & 1.01 & 1.20 \\
\hline HYE28-07 & 1.62 & 1.32 & 1.68 & 0.19 & 1.20 \\
\hline LYE22-12 & 1.37 & 0.66 & 1.44 & 1.30 & 1.19 \\
\hline HYE22-09 & 1.23 & 0.90 & 0.91 & 1.58 & 1.16 \\
\hline HYE12-10 & 1.84 & 0.39 & 0.56 & 1.63 & 1.11 \\
\hline HYE17-04 & 0.20 & 1.46 & 0.93 & 1.61 & 1.05 \\
\hline HYE02-03 & 1.72 & 0.95 & 0.83 & 0.67 & 1.05 \\
\hline LYE25-13 & 1.67 & 1.05 & 0.60 & 0.84 & 1.04 \\
\hline HYE54-05 & 1.20 & 0.83 & 1.05 & 0.77 & 0.96 \\
\hline
\end{tabular}


early- and late-maturing populations for GRS. The early- and late-maturing populations were formed, respectively, by recombining early- or late-maturing plants selected from both the SU and NU populations. The two populations differed in mean days to flowering by about 2-weeks with substantial variation for heading time remaining in each. Van Esbroeck et al. (1998) reported that selection for later maturity increased seasonal biomass production in Alamo switchgrass. Selection nurseries ( $\approx 1000$ plants each) of the early-maturing southern-northern upland (EMSNU) and late-maturing southern-northern upland (LMSNU) populations were planted in 2000. Half-sib seed was harvested from about 120 plants from each nursery in fall 2001. Selection in each nursery was primarily for heading date (early or late) and secondarily for plant vigor and general appearance. Some selections within each population were discarded on the basis of seed quantity/quality or seedling vigor. Half-sib progeny plants and clonal parents of the progeny plants were planted in evaluation nurseries in spring 2002 and will be evaluated at least through the 2003 growing season. Response variables will include days to heading and biomass yield. Parent clones and progeny plants will be included in the two-location test to provide data on genetic parameters.

\section{Inbreeding and Heterosis Studies}

Ongoing research seeks to measure inbreeding depression and heterosis in upland and lowland switchgrass ecotypes to aid in formulating better breeding procedures. This research will determine the extent to which switchgrass can be inbred and the effect of inbreeding on performance traits. It will determine if selection during inbreeding improves plant populations by removing deleterious genes from the population. Finally, it will help determine the presence and magnitude of heterosis for biomass yield.

We continued research on inbreeding effects in switchgrass and the merit of combining inbreeding and selection as a strategy for breeding improvement. Three first selfed generation $\left(\mathrm{S}_{1}\right)$ families (30 plants each) from Blackwell, Caddo, Cave-in-Rock, Kanlow, and Alamo were field-planted in 2000. The best three plants, based on visual assessment, from each of the $15 \mathrm{~S}_{1}$ families were selfed by bagging inflorescences in the field in fall 2001. Seed was harvested and conditioned at the end of the 2001 season, and only 13 out of 45 selfed $S_{1}$ plants produced 20 or more $S_{2}$ seeds. Seven $S_{1}$ plants had more than $100 S_{2}$ seeds. Table 29 lists the plants from which 20 or more $S_{2}$ seeds were harvested. Remnant seed of selected plants in each selfing cycle will be saved for future evaluation of selection effectiveness. After two to three selfing/selection cycles we will evaluate the performance of the cyclic $\left(\mathrm{S}_{0}, \mathrm{~S}_{1}, \mathrm{~S}_{2}\right)$ populations. This research carries the risk that inbreeding depression may severely hamper the ability to advance lines through generations of selfing towards homozygosity.

\section{Heterosis Studies and Feasibility of $\mathbf{F}_{\mathbf{1}}$ Hybrid Switchgrass}

Heterosis, the superior performance of hybrids relative to their parents, has been exploited extensively in allogamous plant species. A heterotic response is expected when there is a difference in gene frequency and some degree of directional dominance at one or more loci conditioning the character. We have evidence of heterotic response in some switchgrass hybrids. Mid- and high-parent heterosis values for three $\mathrm{F}_{1}$ hybrids resulting from crosses of parent plants from three populations (NU 94, NU 93, and SL 93) were calculated from yield data obtained during 1998, 1999, and 2000. Heterosis estimates varied among the three hybrids and 
Table 29. $S_{1}$ plants from which 20 or more $S_{2}$ seeds were obtained in 2001

\begin{tabular}{|c|c|c|}
\hline Origin & $S_{1}$ Family & Plants $\left(\mathrm{S}_{2}\right.$ seeds) \\
\hline Alamo & 3 & Plant 1-3 (30 seeds); Plant 2-5 (20 seeds) \\
\hline Kanlow & 1 & Plant 6-1 (30 seeds) \\
\hline Kanlow & 3 & Plant $2-2$ (20 seeds) \\
\hline Caddo & 1 & Plant 2-4 (100 seeds); Plant 5-2 (200 seeds) \\
\hline Caddo & 3 & Plant $2-4$ (30 seeds) \\
\hline Blackwell & 1 & Plant 2-5 (300 seeds); Plant 4-2 (300 seeds) \\
\hline Blackwell & 2 & Plant 2-5 (200 seeds); Plant 3-1 (40 seeds) \\
\hline Blackwell & 3 & Plant 3-1 (200 seeds) \\
\hline Cave-in-Rock & 2 & Plant 3-4 (350 seeds) \\
\hline
\end{tabular}

varied from year to year. The NU 94 hybrid expressed the highest heterosis with 3-year mean mid- and high-parent values of 56\% and 39\%, respectively. The SL 93 hybrid had 3-year midand high-parent values of $16 \%$ and $-5 \%$, respectively. Mean 3 -year yields showed no heterotic response for the NU 93 hybrid. The heterotic response tended to be highest in the first postestablishment year and tended to decline in following years. Estimates of mid- and high-parent heterosis for nine interploid ( $4 \mathrm{x}$ by $8 \mathrm{x}$, or reciprocal) hybrids were also positive for some combinations based on 2-year mean biomass yields. Data were presented in the year 2000 Annual Report. The combined results document the presence of heterosis in switchgrass and the fact that it is specific for certain hybrid combinations.

To further study heterotic responses in switchgrass, we selected seven elite parents (three with NL background and four with SL background) based on their half-sib performance. These seven clonal parents were intermated in 2001 using a partial diallel design to evaluate their general and specific combining abilities and determine if the northern lowland and the southern lowland are from different heterotic groups. If that is the case, crosses involving both parents would have higher average mean values than crosses involving parents from the same background. If specific combinations are found that produce hybrids with sufficiently high heterotic response, then we will assess the feasibility of their use as commercial cultivars. Each of the diallel crosses was included in a field performance test established in May 2002. The test includes the $F_{1}$ hybrids, other newly developed experimental cultivars, some experimental cultivars with good performance in previous years, and standard controls.

\section{Cytological Studies of Interploidy $F_{1}$ Hybrids}

Nine interploidy ( $8 \mathrm{x}$ by $4 \mathrm{x}$ ) $\mathrm{F}_{1}$ hybrids (verified by chromosome number determinations) were planted in the field in 1998 along with their clonal parental plants. Chromosome numbers and other information on these $\mathrm{F}_{1}$ progeny and their parents were presented in the 1997 annual report. Chromosome pairing, pollen stainability, biomass yield, and other morphological and phenological traits of interploid hybrids and parents were evaluated. Clonal material from each of the seven interploidy $(8 \mathrm{x}$ by $4 \mathrm{x}) \mathrm{F}_{1}$ hybrids and the two backcrosses ( $6 \mathrm{X}$ by $4 \mathrm{X}$ ) and their parents was generated in the greenhouse to establish a field evaluation replicated trial. Twelve clones from each of the interploid hybrids and parents were planted in three replications (4 clonal plants/rep) using a completely randomized design. Observations of chromosome pairing at diakinesis, evaluation of pollen grain stainability, and estimation of the number of seeds per head was conducted in interploid hybrids and parents to assess their fertility. Biomass yield data were collected at the end of the growing seasons in 1999, 2000, and 2001. Plant material was harvested 6 in. above the soil surface and samples were obtained to estimate percent dry matter. Field data were taken in 1999 and in 2000 for some morphological and phenological traits. Traits evaluated 
included: heading date (date when at least three panicles fully exerted above the flag leaf, January $1=1$, December $31=365$ ), plant height (in $\mathrm{cm}$, distance from ground to the tip of the tallest inflorescence), number of nodes per tiller (average from three randomly selected tillers within the center of the crown), ecotype appearance (upland, lowland, or intermediate), foliage color (light green, green, dark green, blue green, or blue), pubescence on upper leaf blade (presence or absence). Results of this study are summarized in Tables 30 and 31. In general, bivalent chromosome pairing at the diakinesis stage of meiosis was observed in microsporocytes of tetraploid and octaploid parents. An array of chromosome pairing (univalents, bivalents, trivalents, and quadrivalents) was observed in microsporocytes from interploid hybrids. Complete pollen staining and production of open pollinated seed were observed in parents and interploid hybrids. Values for biomass yield, heading date, plant height, and other traits for the interploid hybrids were generally intermediate to those of the parents. Backcrosses had values closer to the recurrent parents. Results document the feasibility of transferring genetic material between switchgrass parents of different ploidy level.

Table 30. Chromosome pairing and pollen stainability for parents and interploid hybrids

\begin{tabular}{|c|c|c|c|c|c|c|c|c|c|c|}
\hline \multirow[b]{2}{*}{ Entry } & \multirow[b]{2}{*}{$2 n$} & \multicolumn{5}{|c|}{ Diakinesis } & \multicolumn{4}{|c|}{ Percent pollen stainability } \\
\hline & & $\begin{array}{c}\text { Cells } \\
\text { observed }\end{array}$ & I & II & III & IV & $\mathbf{n}$ & $\begin{array}{c}\text { Completely } \\
\text { stained }\end{array}$ & $\begin{array}{l}\text { Partially } \\
\text { stained }\end{array}$ & $\begin{array}{c}\text { Not } \\
\text { stained }\end{array}$ \\
\hline Alamo-1 (A1) & $2 n=4 X=36$ & 20 & 0 & 18.0 & 0 & 0 & 1500 & 55 & 32.0 & 13 \\
\hline Alamo-2 (A2) & $2 n=4 X=36$ & 15 & 0 & 18.0 & 0 & 0 & 1500 & 62 & 35.0 & 2 \\
\hline Alamo-3 (A3) & $2 n=4 X=36$ & 4 & 0 & 18.0 & 0 & 0 & 1500 & 71 & 27.0 & 2 \\
\hline Kanlow-1 (K1) & $2 n=4 X=36$ & 11 & 0 & 18.0 & 0 & 0 & 1500 & 58 & 36.0 & 6 \\
\hline Kanlow-2 (K2) & $2 n=4 X=36$ & 7 & 0 & 18.0 & 0 & 0 & 1500 & 71 & 25.0 & 4 \\
\hline Summer (S) & $2 n=4 X=36$ & & & & & & 1501 & 68 & 31.0 & 2 \\
\hline Caddo (C1) & $2 n=8 X=72$ & 12 & 0 & 36.0 & 0 & 0 & 1500 & 76 & 22.0 & 3 \\
\hline Caddo (C2) & $2 n=8 X=72$ & & & & & & 1500 & 75 & 24.0 & 1 \\
\hline Caddo (C3) & $2 n=8 X=72$ & 27 & 0 & 36.0 & 0 & 0 & 1500 & 84 & 9.0 & 7 \\
\hline PMT-785 (PMT) & $2 n=8 X=72$ & 6 & 0 & 36.0 & 0 & 0 & 1500 & 58 & 38.0 & 4 \\
\hline SWG-068 (SWG) & $2 n=8 X=72$ & & & & & & 1508 & 83 & 14.0 & 3 \\
\hline $96-23$ & & 13 & 2.1 & 14.8 & 1.2 & 2.2 & 1522 & 73 & 25.6 & 7.1 \\
\hline (SWG X A1)-1 & $2 n=6 X=54$ & 2 & 7.5 & 11.5 & 2.5 & 4.0 & 1828 & 43 & 32.0 & 23 \\
\hline (SWG X A1)-2 & $2 n=6 X=54$ & 19 & 5.5 & 14.2 & 1.3 & 4.1 & 1801 & 43 & 37.0 & $20^{\mathrm{a}}$ \\
\hline (C2 X K2)-1 & $2 n=6 X=54$ & 42 & 9.5 & 10.9 & 2.0 & 4.2 & 1600 & 39 & 40.0 & 21 \\
\hline$(\mathrm{C} 2 \mathrm{X} \mathrm{K} 2)-2$ & $2 n=6 X=54$ & 14 & 7.4 & 16.9 & 1.0 & 2.7 & 1515 & 45 & 31.0 & 24 \\
\hline C1 X S & $2 n=6 X=54$ & 4 & 3.8 & 16.3 & 1.5 & 3.3 & 1999 & 71 & 19.0 & 10 \\
\hline PMT X K1 & $2 n=6 X=54$ & & & & & & 1500 & 52 & 46.0 & 2 \\
\hline C3 X A3 & $2 n=6 X=54$ & 19 & 13.0 & 12.0 & 1.5 & 3.1 & 1500 & 42 & 38.0 & 19 \\
\hline $\begin{array}{l}\text { (SWG X A1)-1 X } \\
\text { A1 }\end{array}$ & $2 n=5 X=45$ & 22 & 4.4 & 10.5 & 1.4 & 3.7 & 1500 & 31 & 32.0 & $37^{\mathrm{a}}$ \\
\hline $\begin{array}{l}\text { (SWG X A1)-2 X } \\
\text { A2 }\end{array}$ & $2 \mathrm{n}=5 \mathrm{X}=45$ & 13 & 2.1 & 14.8 & 1.2 & 2.2 & 1522 & 73 & 26.0 & 2 \\
\hline
\end{tabular}

${ }^{\mathrm{a}}$ Pollen obtained from plants grown in the greenhouse. 
Table 31. Comparisons for biomass yield and other traits among interploid switchgrass hybrids and their parents

\begin{tabular}{|c|c|c|c|c|c|c|c|c|}
\hline Set & Entry & $\begin{array}{c}\text { Biomass } \\
\text { yield } \\
\left(\mathrm{kg} \mathrm{pl}^{-1}\right)\end{array}$ & $\begin{array}{l}\text { Heading } \\
\text { date }\end{array}$ & $\begin{array}{c}\text { Plant } \\
\text { height } \\
\text { (cm) }\end{array}$ & $\begin{array}{l}\text { Number of } \\
\text { nodes/tiller }\end{array}$ & Ecotype & $\begin{array}{l}\text { Color of } \\
\text { leaves }\end{array}$ & Pubescence \\
\hline 1 & SWG-068 & $1.25 \mathrm{c}$ & $211 \mathrm{~b}$ & $138 \mathrm{c}$ & $6.00 \mathrm{a}$ & Upland & Blue & Present \\
\hline 1 & (SWG X A1)-1 & $1.86 \mathrm{~b}$ & $215 b$ & $170 \mathrm{~b}$ & $6.05 \mathrm{a}$ & Upland & Blue-Green & Present \\
\hline 1 & (SWG X A1)-2 & $1.04 \mathrm{~d}$ & $213 b$ & $140 \mathrm{c}$ & $6.33 \mathrm{a}$ & Upland & Blue-Green & Absent \\
\hline 2 & Caddo-2 & $1.23 \mathrm{~b}$ & $212 \mathrm{~b}$ & $174 \mathrm{c}$ & $6.92 \mathrm{ab}$ & Upland & Green & Present \\
\hline 2 & $(\mathrm{C} 2 \mathrm{X} \mathrm{K} 2)-2$ & $1.29 \mathrm{~b}$ & $207 \mathrm{~b}$ & $162 \mathrm{~d}$ & $6.38 \mathrm{~b}$ & Interm & Dark-Green & Present \\
\hline 3 & (SWG X A1)-1 & $1.92 \mathrm{~b}$ & $214 b$ & $158 \mathrm{~b}$ & $5.92 \mathrm{ab}$ & Upland & Blue-Green & Present \\
\hline 3 & Alamo-1 & $3.22 \mathrm{a}$ & $250 \mathrm{a}$ & $215 \mathrm{a}$ & $6.83 \mathrm{a}$ & Lowland & Dark-Green & Absent \\
\hline 3 & (SWG X A1)-1 X A1 & $0.48 \mathrm{c}$ & $235 \mathrm{a}$ & $138 \mathrm{c}$ & $5.50 \mathrm{~b}$ & Upland & Green & Absent \\
\hline 4 & $(\mathrm{SWG} X \mathrm{~A} 1)-2$ & $1.04 \mathrm{c}$ & $213 \mathrm{~b}$ & $140 \mathrm{~b}$ & $6.33 \mathrm{~b}$ & Upland & Blue-Green & Absent \\
\hline 4 & Alamo-2 & $4.05 \mathrm{a}$ & $258 \mathrm{a}$ & $221 \mathrm{a}$ & $7.88 \mathrm{a}$ & Lowland & Dark-Green & Absent \\
\hline 6 & PMT-785 & $1.61 \mathrm{c}$ & $257 \mathrm{a}$ & $163 \mathrm{~b}$ & $7.67 \mathrm{a}$ & Lowland & Dark-Green & Absent \\
\hline 6 & Kanlow-1 & $3.84 \mathrm{a}$ & $258 \mathrm{a}$ & $234 \mathrm{a}$ & $7.33 \mathrm{a}$ & Lowland & Dark-Green & Present \\
\hline 6 & PMT X K1 & $3.30 \mathrm{~b}$ & $257 \mathrm{a}$ & $225 \mathrm{a}$ & $4.71 \mathrm{~b}$ & Lowland & Dark-Green & Present \\
\hline 7 & Caddo-3 & $1.05 \mathrm{c}$ & $209 \mathrm{~b}$ & $139 \mathrm{c}$ & $5.96 \mathrm{~b}$ & Upland & Blue-Green & Present \\
\hline 7 & Alamo-3 & $3.73 \mathrm{a}$ & $256 \mathrm{a}$ & $228 \mathrm{a}$ & $7.42 \mathrm{a}$ & Lowland & Green & Absent \\
\hline 7 & $\mathrm{C} 3 \mathrm{X} \mathrm{A} 3$ & $1.78 \mathrm{~b}$ & $243 \mathrm{a}$ & $158 \mathrm{~b}$ & $5.54 \mathrm{~b}$ & Interm & Blue-Green & Present \\
\hline
\end{tabular}

\section{Southern Regional Yield Trial}

An experiment was initiated in 1993 to evaluate the yield and persistence of twelve switchgrass populations (cultivars and cultivar blends) at six locations across the southern United States. Seeded sward plots were established at Chickasha and Haskell, Oklahoma; Stephenville and College Station, Texas; Auburn, Alabama; and Blacksburg, Virginia. A randomized complete block with three or four (Blacksburg) replications was used. Plots were harvested in 1994 and 1995 at each location. Biomass yield data for each location were included in the 1996 annual report. Genotype by environment (GXE) interactions were substantial in both years (1994 and 1995). Despite GXE interactions, important trends in biomass yield were evident. Alamo and blends containing Alamo were among the highest yielding cultivars in almost all environments, whereas Shelter and Summer were consistently among the least productive populations. The most productive location was Haskell, Oklahoma.

This study was continued through 2001 at Haskell and Chickasha, Oklahoma. Stands of Shelter and Summer were poor in the Chickasha test, hence we have excluded these two cultivars from the Chickasha location data analyses. Here we report 8-year (1994-2001) biomass yield data from these two locations. In addition, results from stability analysis of cultivars based on data from 1994-2000 are included. Analysis of variance for the combined data across years and locations revealed significant differences among cultivars $(\mathrm{P}<0.0001)$, locations $(\mathrm{P}<0.0001)$, years $(\mathrm{P}<0.0001)$, year $\mathrm{X}$ location $(\mathrm{P}<0.0001)$, and cultivar $\mathrm{X}$ year $\mathrm{X}$ location $(\mathrm{P}<0.0001)$. We have, therefore, conducted and included separate analyses by locations and years within location. 
Table 32 summarizes data from Chickasha. Significant differences among cultivars were detected each year, except 1996 and 1999 ( $\mathrm{P}=0.1909$ and 0.0852, respectively). Analysis of variance across years revealed significant differences among cultivars $(\mathrm{P}<0.0001)$, years $(\mathrm{P}<0.0001)$, and the cultivar $\mathrm{X}$ year $(\mathrm{P}<0.0001)$ interaction. Alamo and Kanlow and their blends had higher biomass yields than the other cultivars, with 8-year means at or above 5.4 tons/acre. Cave-in-Rock, Caddo, and Blackwell were the lowest yielding cultivars.

Table 32. Biomass yield (tons/acre) for switchgrass cultivars in the 1993 Southern Regional Yield Trial at Chickasha, Oklahoma

\begin{tabular}{|c|c|c|c|c|c|c|c|c|c|}
\hline \multirow[b]{2}{*}{ Entry } & \multicolumn{9}{|c|}{ Year } \\
\hline & 1994 & 1995 & 1996 & 1997 & 1998 & 1999 & 2000 & 2001 & Mean \\
\hline Alamo + Summer & 5.12 & 9.84 & 6.25 & 4.99 & 3.99 & 6.77 & 5.15 & 3.46 & 5.70 \\
\hline Kanlow & 4.88 & 11.8 & 4.51 & 4.19 & 3.34 & 6.66 & 5.54 & 3.47 & 5.55 \\
\hline Kanlow + Alamo & 5.56 & 10.55 & 5.25 & 4.45 & 3.50 & 5.86 & 4.93 & 3.06 & 5.40 \\
\hline Alamo & 6.05 & 9.52 & 5.55 & 4.38 & 3.00 & 6.19 & 5.25 & 3.40 & 5.42 \\
\hline PMT-279 & 5.35 & 9.43 & 4.23 & 4.02 & 3.19 & 6.3 & 4.72 & 3.51 & 5.09 \\
\hline Blackwell + Kanlow & 4.98 & 7.56 & 4.72 & 4.3 & 2.86 & 4.75 & 5.39 & 3.10 & 4.71 \\
\hline Late Synthetic High Yield & 5.52 & 7.54 & 4.81 & 3.47 & 2.66 & 4.62 & 4.82 & 2.64 & 4.51 \\
\hline Blackwell & 6.01 & 5.27 & 4.23 & 4.03 & 2.82 & 5.52 & 4.70 & 3.06 & 4.46 \\
\hline Caddo & 4.94 & 6.77 & 3.63 & 2.8 & 2.33 & 5.15 & 4.79 & 2.94 & 4.17 \\
\hline Cave-in-Rock & 2.5 & 4.21 & 3.67 & 3.18 & 2.23 & 4.64 & 3.33 & 2.34 & 3.26 \\
\hline LSD & 1.32 & 2.58 & 1.94 & 0.83 & 1.0 & 1.7 & 1.07 & 0.61 & 0.47 \\
\hline Mean & 5.09 & 8.25 & 4.69 & 3.98 & 2.99 & 5.65 & 4.86 & 3.10 & 4.83 \\
\hline C.V. & 15.08 & 18.23 & 24.14 & 12.18 & 19.39 & 17.5 & 12.84 & 11.46 & 17.18 \\
\hline $\mathrm{P}>\mathrm{F}$ for entries & 0.0016 & 0.0002 & 0.1909 & 0.0011 & 0.0412 & 0.0852 & 0.026 & 0.0108 & $<0.0001$ \\
\hline $\mathrm{P}>\mathrm{F}$ for years & & & & & & & & & $<0.0001$ \\
\hline $\mathrm{P}>\mathrm{F}$ for entry $\mathrm{X}$ year & & & & & & & & & $<0.0001$ \\
\hline
\end{tabular}

Table 33 summarizes data from Haskell. Significant differences among cultivars were detected each year. Analyses of variance across years revealed significant differences among cultivars $(\mathrm{P}<0.0001)$, years $(\mathrm{P}<0.0001)$, and for the cultivar $\mathrm{X}$ year $(\mathrm{P}<0.0001)$ interaction. Again, Alamo, Kanlow, and their blends had significantly higher biomass yields than did the rest of the cultivars, with 8 -year biomass yield means at or above 7.3 tons/acre. Stands were uniform among plots, and Summer and Shelter are included in the analysis. Those two cultivars had the lowest biomass yields.

Table 34 summarizes results of the analyses for combined data from Chickasha and Haskell. Significant differences among cultivars were observed each year. Locations differed each year, except for $1995(\mathrm{P}=0.4238)$. Analyses of variance for the combined data across years and locations revealed significant differences among cultivars $(\mathrm{P}<0.0001)$, locations $(\mathrm{P}<0.0001)$, years $(\mathrm{P}<0.0001)$, and the year $\mathrm{X}$ location $(\mathrm{P}<0.0001)$, and cultivar $\mathrm{X}$ year $\mathrm{X}$ location $(\mathrm{P}<0.0001)$ interactions. Across years and locations, Alamo and Kanlow and their blends with other cultivars had biomass yields significantly higher than other cultivars, with 8-year means at or above 6.4 tons/acre. Cave-in-Rock, Caddo, and Late Synthetic High Yield had the lowest biomass yields among cultivars. Yields at Haskell were significantly higher than those in Chickasha (6.63 vs. 4.82 tons/acre/year). Stands of some cultivars in the Chickasha test thinned over time, partially accounting for lower yields at that location. 
Table 33. Biomass yield (tons/acre) of switchgrass cultivars at the 1993 Southern Regional Yield Trial in Haskell, Oklahoma

\begin{tabular}{|c|c|c|c|c|c|c|c|c|c|}
\hline \multirow[b]{2}{*}{ Entry } & \multicolumn{9}{|c|}{ Year } \\
\hline & 1994 & 1995 & 1996 & 1997 & 1998 & 1999 & 2000 & 2001 & Mean \\
\hline Alamo + Summer & 11.49 & 9.67 & 9.50 & 6.58 & 7.74 & 5.46 & 8.77 & 5.98 & 8.15 \\
\hline Kanlow + Alamo & 9.75 & 10.59 & 9.66 & 5.96 & 7.53 & 5.72 & 7.25 & 5.50 & 7.74 \\
\hline Kanlow & 9.00 & 7.99 & 8.35 & 5.97 & 7.91 & 6.92 & 9.21 & 4.75 & 7.51 \\
\hline Alamo & 11.87 & 7.63 & 7.01 & 5.79 & 7.49 & 5.96 & 7.37 & 5.41 & 7.32 \\
\hline PMT-279 & 7.74 & 8.24 & 8.21 & 6.09 & 8.89 & 5.77 & 7.13 & 4.34 & 7.05 \\
\hline Blackwell + Kanlow & 11.14 & 7.08 & 8.05 & 5.44 & 6.14 & 6.03 & 8.05 & 4.87 & 7.10 \\
\hline Blackwell & 7.50 & 9.05 & 5.09 & 2.93 & 5.57 & 4.17 & 5.66 & 4.78 & 5.59 \\
\hline Caddo & 8.28 & 7.55 & 5.42 & 3.23 & 4.80 & 4.68 & 5.60 & 4.09 & 5.46 \\
\hline Cave-in-Rock & 7.05 & 9.38 & 6.22 & 2.64 & 4.10 & 3.52 & 5.31 & 3.74 & 5.25 \\
\hline Late Synthetic High Yield & 7.52 & 8.59 & 5.17 & 2.61 & 4.67 & 3.82 & 5.30 & 3.88 & 5.19 \\
\hline Shelter & 6.78 & 8.44 & 4.86 & 2.66 & 3.60 & 3.34 & 4.49 & 2.98 & 4.64 \\
\hline Summer & 3.56 & 4.73 & 4.67 & 2.33 & 3.57 & 3.56 & 6.52 & 3.98 & 4.12 \\
\hline LSD & 3.32 & 2.57 & 2.54 & 0.8 & 1.46 & 1.02 & 1.54 & 1.15 & 0.67 \\
\hline Mean & 8.47 & 8.25 & 6.85 & 4.35 & 6 & 4.91 & 6.72 & 4.52 & 6.26 \\
\hline C.V. & 23.11 & 18.4 & 21.86 & 10.87 & 14.41 & 12.32 & 13.56 & 14.98 & 18.86 \\
\hline$P>F$ for entries & 0.0016 & 0.0167 & 0.0012 & $<0.0001$ & $<0.0001$ & $<0.0001$ & $<0.0001$ & 0.0009 & $<0.0001$ \\
\hline $\begin{array}{l}P>F \text { for years } \\
P>F \text { for entry } X \text { year }\end{array}$ & & & & & & & & & $\begin{array}{l}<0.0001 \\
<0.0001\end{array}$ \\
\hline
\end{tabular}

Values for each of the five stability parameters for each cultivar are summarized in Table 35. Wricke's (1962) ecovalence ( $\mathrm{W}_{i}^{2}$ ) values ranged from 12.05 for Caddo to 49.23 for Kanlow. Five of the ten cultivars had significant $\mathrm{W}_{i}^{2}$ values when tested using the procedure described by Kang and Miller (1984). Shukla's (1972) stability variance $\left(\sigma_{i}^{2}\right)$ values ranged from 0.82 for Caddo to 4.39 for Kanlow. Five of the ten cultivars had values for $\sigma_{i}^{2}$ significantly different from zero. The significant $\mathrm{W}_{i}^{2}$ and $\sigma_{i}^{2}$ values are considered as indicators of low stability for DM yield. None of Shukla's s ${ }_{i}^{2}$ values, ranging from 0.25 for Caddo to 1.53 for Kanlow and Cave-in-Rock, were significant. Values for $\mathrm{s}_{i}^{2}$ are obtained after the effect of the covariate has been removed from the $\mathrm{CE}$ interaction sum of squares as heterogeneity of regression and they are part of the residual variance of the CE interaction. The discrepancy between $\sigma_{i}^{2}$ and $\mathbf{s}_{i}^{2}$ as indicators of cultivar stability is due to the linear effect of the covariate. Use of covariate analysis was effective in removing this effect. Based on $\mathrm{s}_{i}^{2}$, all of the ten switchgrass cultivars evaluated for stability had stable biomass production across the range of environmental conditions tested. Analysis of stability using Finlay and Wilkinson's (1963) $\left(b_{i}\right)$ regression coefficient revealed that only one cultivar, the blend Alamo and Kanlow, had a regression coefficient significantly higher than 1.0 $\left(b_{i}=1.32\right)$. The rest of the cultivars had $b_{i}$ values ranging from 0.95 for Late Synthetic High Yield to 1.27 for the Alamo and Summer blend. Eberhart and Russel's (1966) deviation from regression $\left(\delta_{i}^{2}\right)$ values for all cultivars were not different from zero, except for PMT-279 $\left(\delta_{i}^{2}=3.07\right)$. 
Table 34. Mean biomass yield (tons/acre) of switchgrass cultivars in the 1993 Southern Regional Yield Trial in Chickasha and Haskell, Oklahoma

\begin{tabular}{|c|c|c|c|c|c|c|c|c|c|}
\hline \multirow[b]{2}{*}{ Entry } & \multicolumn{8}{|c|}{ Year } & \multirow[b]{2}{*}{ Mean } \\
\hline & 1994 & 1995 & 1996 & 1997 & 1998 & 1999 & 2000 & 2001 & \\
\hline Alamo + Summer & 8.31 & 9.76 & 7.88 & 5.78 & 5.87 & 6.12 & 6.96 & 4.73 & 6.92 \\
\hline Kanlow + Alamo & 7.65 & 10.57 & 7.46 & 5.2 & 5.52 & 5.79 & 6.09 & 4.28 & 6.57 \\
\hline Kanlow & 6.94 & 9.89 & 6.43 & 5.08 & 5.63 & 6.79 & 7.38 & 4.11 & 6.53 \\
\hline Alamo & 8.96 & 8.56 & 6.28 & 5.08 & 5.25 & 6.08 & 6.31 & 4.41 & 6.37 \\
\hline PMT-279 & 6.55 & 8.84 & 6.22 & 5.05 & 6.04 & 6.04 & 5.92 & 3.92 & 6.07 \\
\hline Blackwell + Kanlow & 8.06 & 7.32 & 6.38 & 4.87 & 4.5 & 5.39 & 6.72 & 3.98 & 5.90 \\
\hline Blackwell & 6.75 & 7.16 & 4.66 & 3.48 & 4.19 & 4.84 & 5.18 & 3.92 & 5.02 \\
\hline $\begin{array}{l}\text { Late Synthetic High } \\
\text { Yield }\end{array}$ & 6.52 & 8.07 & 4.99 & 3.04 & 3.67 & 4.22 & 5.06 & 3.26 & 4.85 \\
\hline Caddo & 6.61 & 7.16 & 4.53 & 3.02 & 3.56 & 4.92 & 5.19 & 3.52 & 4.81 \\
\hline Cave-in-Rock & 4.78 & 6.8 & 4.95 & 2.91 & 3.17 & 4.08 & 4.31 & 3.04 & 4.25 \\
\hline LSD & 1.85 & 1.84 & 1.65 & 0.59 & 0.87 & 0.98 & 0.93 & 0.60 & 0.43 \\
\hline Mean & 7.11 & 8.41 & 5.98 & 4.35 & 4.74 & 5.43 & 5.91 & 3.92 & 5.73 \\
\hline C.V. & 22.17 & 18.7 & 23.55 & 11.51 & 15.68 & 15.36 & 13.42 & 13.17 & 18.55 \\
\hline $\mathrm{P}>\mathrm{F}$ for entries & 0.0043 & 0.0008 & 0.0011 & $<0.0001$ & $<0.0001$ & $<0.0001$ & $<0.0001$ & 0.0397 & $<0.0001$ \\
\hline $\mathrm{P}>\mathrm{F}$ for location & $<0.0001$ & 0.4238 & $<0.0001$ & $<0.0001$ & $<0.0001$ & 0.0473 & $<0.0001$ & $<0.0001$ & $<0.0001$ \\
\hline $\begin{array}{l}\mathrm{P}>\mathrm{F} \text { for entry } \mathrm{X} \\
\text { Location }\end{array}$ & 0.0966 & 0.001 & 0.1891 & $<0.0001$ & 0.001 & 0.2343 & 0.0118 & 0.1105 & 0.2199 \\
\hline $\mathrm{P}>\mathrm{F}$ for year & & & & & & & & & $<0.0001$ \\
\hline $\begin{array}{l}\mathrm{P}>\mathrm{F} \text { for year } \mathrm{X} \\
\text { Location }\end{array}$ & & & & & & & & & $<0.0001$ \\
\hline$P>F$ for year $X$ entry & & & & & & & & & 0.9816 \\
\hline Mean Haskell & 9.13 & 8.58 & 7.27 & 4.72 & 6.48 & 5.21 & 6.96 & 4.73 & 6.63 \\
\hline Mean Chickasha & 5.09 & 8.25 & 4.69 & 3.98 & 2.99 & 5.65 & 4.86 & 3.10 & 4.83 \\
\hline LSD & 0.83 & 0.82 & 0.74 & 0.26 & 0.39 & 0.44 & 0.42 & 0.27 & 0.19 \\
\hline
\end{tabular}

Table 35. Summary of five stability parameters for each of the cultivars evaluated

\begin{tabular}{|c|c|c|c|c|c|}
\hline Entry & $\begin{array}{c}\text { Wricke's } \\
\mathbf{W}_{i}^{2}\end{array}$ & $\begin{array}{c}\text { Shukla's } \\
\sigma_{i}^{2}\end{array}$ & $\begin{array}{c}\text { Shukla's } \\
\mathbf{s}_{i}^{2} \\
\end{array}$ & $\begin{array}{c}\text { Finlay and } \\
\text { Wilkinson's } \\
b_{i}\end{array}$ & $\begin{array}{c}\text { Eberhart and } \\
\text { Russel's } \\
\delta_{i}^{2} \\
\end{array}$ \\
\hline AlSummer & 19.88 & 1.57 & 0.39 & 1.27 & 1.89 \\
\hline KanAlamo & 23.96 & 1.96 & 0.46 & $1.32^{\mathrm{a}}$ & 1.66 \\
\hline Kanlow & $49.23^{\mathrm{a}}$ & $4.39^{\mathrm{a}}$ & 1.53 & 1.21 & 2.18 \\
\hline Alamo & 27.55 & 2.31 & 0.80 & 1.16 & 2.35 \\
\hline PMT-279 & $32.96^{\mathrm{a}}$ & $2.82^{\mathrm{a}}$ & 1.02 & 1.00 & $3.07^{\mathrm{a}}$ \\
\hline BlKanlow & $31.67^{\mathrm{a}}$ & $2.70^{\mathrm{a}}$ & 0.99 & 1.05 & 3.69 \\
\hline Blackwell & $45.99^{\mathrm{a}}$ & $4.09^{\mathrm{a}}$ & 1.16 & 0.79 & 1.26 \\
\hline Caddo & 12.05 & 0.82 & 0.25 & 0.96 & 0.78 \\
\hline CIR & $48.38^{\mathrm{a}}$ & $4.31^{\mathrm{a}}$ & 1.53 & 0.96 & 0.92 \\
\hline LateSyn & 29.95 & 2.53 & 0.84 & 0.95 & 1.72 \\
\hline
\end{tabular}


The results are of practical significance because they demonstrate the ability of adapted switchgrass cultivars to maintain good stands and high biomass production potential over a long period of time. The high mean DM yields and relatively good stability of Alamo ( $\bar{X}=6.37$ tons $\left.\mathrm{DM} \mathrm{acre}^{-1}, b_{i}=1.16, \delta_{i}^{2}=2.35, \mathrm{~s}_{i}^{2}=0.80\right)$ and Kanlow $\left(\bar{X}=6.53\right.$ tons DM acre ${ }^{-1}$, $\left.b_{i}=1.21, \delta_{i}^{2}=2.18, \mathrm{~s}_{i}^{2}=1.53\right)$ make them choice candidates for use as bioenergy feedstock crops under the conditions tested. As new switchgrass breeding lines and cultivars are performance tested in different environments, the use of stability parameters will enhance the effectiveness of identifying the most stable cultivars.

\section{GERMPLASM COLLECTION, EVALUATION, AND ENHANCEMENT}

A total of 115 switchgrass germplasm accessions were assembled into a collection and evaluated for standard descriptors (Table 4). Nine core subsets comprising 110 switchgrass germplasm accessions were developed based on plant descriptors including chromosome number, ecotype, and similarity in morphological and flowering characteristics. Table 36 lists the clusters and gives descriptor data for each accession within the respective clusters. Cluster analyses were used to separate the accessions into the nine core groups. The nine core groups were planted in isolated polycross nurseries in spring 2001. Seed of each core group will be harvested and placed in the NPGS for long-term maintenance. This will provide a well-characterized switchgrass germplasm resource for use in switchgrass research. 
Table 36. Descriptor information for switchgrass germplasm accessions within each of nine clusters

\begin{tabular}{|c|c|c|c|c|c|c|c|c|c|c|c|c|c|c|}
\hline 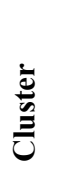 & 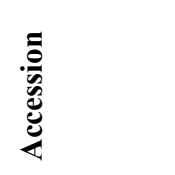 & $\frac{\overrightarrow{0}}{\frac{0}{0}}$ & $\sum_{\substack{0 \\
0}}^{0}$ & 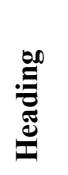 & 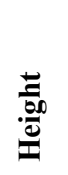 & 를 & 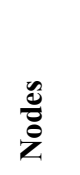 & 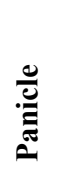 & 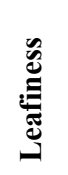 & 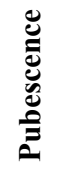 & 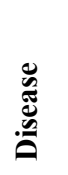 & $\frac{\dot{\theta}}{\dot{\theta}}$ & & $\stackrel{0}{\not}$ \\
\hline 1 & SWG034 & $4 x$ & Lowland & 231 & 227 & 1687 & 8 & 7.3 & 5.7 & 1 & 5.7 & 4 & 4 & 6 \\
\hline 1 & SWG047 & $4 x$ & Lowland & 231 & 247 & 1538 & 8.33 & 7.3 & 6.7 & 1 & 6 & 3.33 & 3 & 6.3 \\
\hline 1 & Alamo & $4 x$ & Lowland & 233 & 210 & 3058 & 7 & 7 & 6.3 & 1.1 & 7 & 3.67 & 5.33 & 6.9 \\
\hline 1 & SWG043 & $4 x$ & Lowland & 233 & 257 & 1971 & 8.33 & 7 & 5.3 & 1 & 6.3 & 4 & & 5.7 \\
\hline 1 & SWG049 & $4 x$ & Lowland & 233 & 247 & 1588 & 8.33 & 6.7 & 5.7 & 1 & 6.3 & 3.33 & 4 & 6.7 \\
\hline 1 & SWG036 & $4 x$ & Lowland & 234 & 238 & 1694 & 8.67 & 7 & 5.7 & 1 & 6.3 & 4 & 4 & 6.7 \\
\hline 1 & SWG037 & $4 x$ & Lowland & 236 & 235 & 1429 & 9.33 & 7 & 6 & 1.7 & 5.3 & 4 & 4 & 6.3 \\
\hline 1 & Wabasso & $4 x$ & Lowland & 237 & 204 & 1404 & 5.83 & 6.7 & 6.7 & 1 & 8 & 1.83 & 7 & 6.7 \\
\hline 1 & Alamo TC & $4 x$ & Lowland & 244 & 192 & 1772 & 7.39 & 5.7 & 6.9 & 1 & 6.9 & 3.94 & & 6.4 \\
\hline 1 & Miami & $4 x$ & Lowland & 244 & 235 & 2193 & 7.5 & 6.8 & 6.3 & 1.7 & 7.7 & 2.67 & 8 & 7 \\
\hline 1 & Stuart & $4 x$ & Lowland & 247 & 234 & 2158 & 7.33 & 7.2 & 7 & 1 & 8.3 & 2 & 7 & 7 \\
\hline 1 & TX 1 & $4 x$ & Lowland & 228 & 195 & 1067 & 6 & 7 & 6 & 1 & 7 & 3 & & 7 \\
\hline 1 & РМТ279 & $4 x$ & Lowland & 224 & 230 & 2616 & 7.33 & 6.3 & 6 & 1 & 7 & 3 & 6 & 6.7 \\
\hline 1 & SWG033 & $4 x$ & Lowland & 224 & 225 & 1610 & 7.67 & 7.3 & 5.3 & 1 & 5.7 & 4 & 4 & 6 \\
\hline 2 & SWG048 & $4 x$ & Lowland & 220 & 233 & 1575 & 8.67 & 7 & 6 & 1 & 5.7 & 3.33 & 4 & 6.3 \\
\hline 2 & SWG022 & $4 x$ & Lowland & 221 & 200 & 1933 & 7.67 & 8.3 & 6.3 & 1 & 8 & 4.67 & 7 & 6.3 \\
\hline 2 & SWG005 & $4 x$ & Lowland & 222 & 232 & 2983 & 8 & 6 & 5.3 & 1 & 7.7 & 4 & 5 & 6 \\
\hline 2 & SWG021 & $4 x$ & Lowland & 222 & 213 & 1604 & 7.67 & 7.3 & 6.3 & 1 & 7.3 & 4.33 & 5 & 6 \\
\hline 2 & SWG005op & $4 x$ & Lowland & 222 & 240 & 2580 & 8 & 7 & 5.7 & 1 & 7 & 4 & 4 & 6.3 \\
\hline 2 & SWG032 & $4 x$ & Lowland & 222 & 215 & 1231 & 8.33 & 6.3 & 5.3 & 1.3 & 5.3 & 3 & 5 & 6 \\
\hline 2 & SWG035 & $4 x$ & Lowland & 222 & 227 & 1519 & 7 & 7.7 & 5 & 1 & 6.3 & 4.33 & 4 & 6.3 \\
\hline 2 & SWG044 & $4 x$ & Lowland & 222 & 228 & 1538 & 8.33 & 7.3 & 5.7 & 1 & 6.3 & 3.33 & & 7 \\
\hline 2 & SWG021op & $4 x$ & Lowland & 224 & 197 & 1460 & 8 & 7 & 6 & 1 & 7.3 & 4.33 & 4 & 6.7 \\
\hline 2 & Kanlow & $4 x$ & Lowland & 225 & 217 & 2439 & 7.33 & 6.3 & 5.7 & 1 & 6.3 & 4 & 6 & 6.3 \\
\hline 2 & SWG020 & $4 x$ & Lowland & 225 & 207 & 2015 & 7.33 & 7.3 & 6 & 1 & 7 & 4 & 4 & 6.7 \\
\hline 2 & MS 4 & $4 x$ & Lowland & 225 & 208 & 1421 & 7.5 & 6.8 & 5.7 & 1 & 6.8 & 4.5 & 4.5 & 5.8 \\
\hline 2 & SWG024 & $4 x$ & Lowland & 226 & 193 & 1925 & 7 & 7.3 & 6.3 & 1 & 6.7 & 4.67 & 5 & 6.7 \\
\hline 2 & SWG051 & $4 x$ & Lowland & 226 & 220 & 1985 & 7 & 7 & 6 & 1 & 7 & 4 & 6.5 & 6 \\
\hline 2 & SWG045 & $4 x$ & Lowland & 226 & 250 & 1670 & 7.67 & 7 & 5.3 & 1 & 6.3 & 4 & 5 & 5.5 \\
\hline 2 & MS 6 & $4 x$ & Lowland & 226 & 160 & 1057 & 5.83 & 7 & 7.2 & 2 & 7.3 & 2.5 & 7.5 & 7.2 \\
\hline 2 & SWG031 & $4 x$ & Lowland & 228 & 227 & 1682 & 8.33 & 7.3 & 5.3 & 1 & 5.7 & 4 & 4 & 6.7 \\
\hline 2 & SWG046 & $4 x$ & Lowland & 228 & 250 & 1031 & 8.67 & 7.3 & 5 & 1 & 6 & 2.67 & 4 & 7 \\
\hline 2 & SWG030 & $4 x$ & Lowland & 229 & 227 & 1274 & 8 & 6.7 & 6 & 1 & 5.7 & 4.67 & 6 & 7 \\
\hline 3 & SWG040 & $4 x$ & Lowland & 212 & 225 & 1238 & 7.33 & 7 & 6.3 & 1.3 & 7 & 4 & 3 & 6.7 \\
\hline 3 & SWG003 & $4 x$ & Lowland & 213 & 227 & 1392 & 7.33 & 6.3 & 5.7 & 1 & 8 & 4 & 4 & 7 \\
\hline 3 & PI 422016 & $4 x$ & Lowland & 213 & 173 & 1192 & 7 & 8 & 6 & 1 & 7 & 5 & & 7 \\
\hline 3 & SWG003op & $4 x$ & Lowland & 214 & 223 & 1754 & 7 & 7 & 5.7 & 1 & 7 & 4 & 4 & 6.7 \\
\hline 3 & SWG039 & $4 x$ & Lowland & 214 & 220 & 1929 & 7.33 & 6.7 & 6 & 1 & 6.7 & 4 & 4 & 7 \\
\hline 3 & SWG002 & $4 x$ & Lowland & 215 & 212 & 2780 & 7.67 & 6 & 5.3 & 1 & 8 & 4.33 & 4 & 6 \\
\hline 3 & SWG038 & $4 x$ & Lowland & 215 & 218 & 1480 & 7.67 & 7.3 & 5.7 & 1 & 6.7 & 4 & 4 & 6.7 \\
\hline 3 & Pangburn & $4 x$ & Lowland & 215 & 220 & 1787 & 7.86 & 7.2 & 6 & 1.1 & 6.6 & 4.33 & 4.48 & 6.4 \\
\hline 3 & SWG002op & $4 x$ & Lowland & 217 & 220 & 2231 & 7.67 & 7.3 & 5.7 & 1 & 7 & 3 & 5 & 6 \\
\hline 3 & SWG042 & $4 x$ & Lowland & 218 & 231 & 1622 & 8 & 7.3 & 5.7 & 1 & 6.7 & 3.67 & 3 & 6.3 \\
\hline 3 & SWG004 & $4 x$ & Lowland & 219 & 230 & 2030 & 8 & 6.3 & 5 & 1 & 7 & 4 & 4 & 6.3 \\
\hline 3 & SWG029 & $4 x$ & Lowland & 219 & 203 & 1806 & 8 & 6.7 & 5.6 & 1 & 7 & 5 & 5 & 7.7 \\
\hline 4 & TN104 & $4 x$ & Upland & 214 & 175 & 1200 & 6.67 & 8.2 & 6.8 & 1.3 & 7.8 & 3.17 & 6 & 6.8 \\
\hline 4 & AR4 & $4 x$ & Upland & 222 & 131 & 758 & 5.67 & 7.5 & 6.8 & 2.3 & 7.2 & 2.17 & 8 & 6.8 \\
\hline 4 & TN103 & $4 x$ & Upland & 229 & 163 & 729 & 6.5 & 7.3 & 6.8 & 1.3 & 6.8 & 2.83 & 6.5 & 7.7 \\
\hline
\end{tabular}


Table 36. (Continued)

\begin{tabular}{|c|c|c|c|c|c|c|c|c|c|c|c|c|c|c|}
\hline$\frac{\grave{\Xi}}{\stackrel{\Xi}{\Xi}}$ & 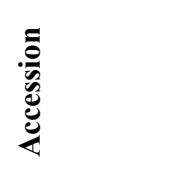 & $\frac{\overrightarrow{0}}{\frac{0}{2}}$ & 㫄 & $\stackrel{000}{\stackrel{\Xi}{\Xi}}$ & 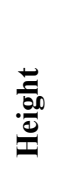 & 를 & $\frac{\tilde{g}}{\tilde{g}}$ & 元 & 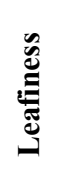 & 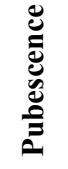 & 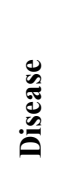 & $\dot{\bar{\theta}}$ & 些 & $\sum_{E}^{0}$ \\
\hline 5 & $\mathrm{NC} 1$ & $4 x$ & Upland & 176 & 63.3 & 26 & 4 & 5.7 & 5.7 & 2 & 5.7 & 2.33 & 7 & 6.7 \\
\hline 5 & Summer & $4 x$ & Upland & 192 & 133 & 380 & 7.5 & 6 & 5.5 & 3 & 6 & 2 & 6.5 & 6.3 \\
\hline 5 & MO101 & $4 x$ & Upland & 202 & 115 & 596 & 5.67 & 6.7 & 6 & 1.8 & 6.5 & 3.83 & 8 & 4.5 \\
\hline 5 & MO100 & $4 x$ & Upland & 208 & 103 & 551 & 5.5 & 7.3 & 5.8 & 3.8 & 6.7 & 1.83 & 8 & 5.3 \\
\hline 6 & AL5 & $8 x$ & Upland & 248 & 155 & 1326 & 5.17 & 7.3 & 6.2 & 5.5 & 6.3 & 2.67 & 7 & 6.8 \\
\hline 6 & MS5 & $8 x$ & Upland & 257 & 123 & 817 & 5 & 6.7 & 6.3 & 1.7 & 6.7 & 2.67 & 6 & 7 \\
\hline 7 & AR5 & $8 x$ & Upland & 220 & 144 & 616 & 5.83 & 6.7 & 6 & 4.8 & 6 & 3.5 & 4.5 & 7.2 \\
\hline 7 & $\begin{array}{l}\text { GA } \\
\text { PMC682 }\end{array}$ & $8 x$ & Upland & 219 & 130 & 116 & & & & 2 & 9 & & & \\
\hline 7 & SWG068 & $8 x$ & Upland & 219 & 152 & 650 & 6 & 6 & 6 & 3 & 7 & 4 & 6 & 5 \\
\hline 7 & $\begin{array}{l}\text { GA } \\
\text { PMC75 }\end{array}$ & $8 x$ & Upland & 220 & 165 & 503 & & & & 1 & 8 & & & \\
\hline 7 & $\begin{array}{l}\text { GA } \\
\text { PMC536 }\end{array}$ & $8 x$ & Upland & 220 & 145 & 1048 & & & & 3 & 8 & & & \\
\hline 7 & AR6 & $8 x$ & Upland & 220 & 158 & 735 & 6.5 & 7.2 & 6.7 & 4.7 & 6.8 & 4.83 & 7 & 7.2 \\
\hline 7 & AR5 & $8 x$ & Upland & 220 & 144 & 616 & 5.83 & 6.7 & 6 & 4.8 & 6 & 3.5 & 4.5 & 7.2 \\
\hline 7 & SWG006op & $8 x$ & Upland & 221 & 153 & 658 & 6.33 & 6 & 6 & 2.7 & 5.7 & 1.67 & 4 & 7.3 \\
\hline 7 & TN100 & $8 x$ & Upland & 221 & 128 & 568 & 5.67 & 7 & 6.5 & 3.5 & 7.3 & 3.33 & 6.5 & 6.8 \\
\hline 7 & GA 3 & $8 x$ & Upland & 222 & 127 & 606 & 5.5 & 6.7 & 6.7 & 6.3 & 6.8 & 2.83 & 6.5 & 5.8 \\
\hline 7 & AL 1 & $8 x$ & Upland & 222 & 132 & 534 & 4.5 & 6.5 & 6.5 & 6 & 7 & 3.17 & 6 & 6.5 \\
\hline 7 & SWG001 & $8 x$ & Upland & 226 & 125 & 576 & 5.67 & 7 & 6 & 3.7 & 6.7 & 1.67 & & 6.67 \\
\hline 7 & $\begin{array}{l}\text { GA } \\
\text { PMC331 }\end{array}$ & $8 x$ & Upland & 226 & 135 & 761 & & & & 3 & 7 & & & \\
\hline 7 & $\mathrm{NC} 2$ & $8 x$ & Upland & 226 & 158 & 605 & 5.5 & 7.2 & 6.3 & 2.5 & 7 & 3 & 5.5 & 7.2 \\
\hline 7 & AL 2 & $8 x$ & Upland & 227 & 103 & 199 & 4 & 6.3 & 6.7 & 3 & 5.7 & 2 & 6 & 6 \\
\hline 7 & TN105 & $8 x$ & Upland & 229 & 160 & 786 & 5.17 & 7 & 6.8 & 1.8 & 6.8 & 2.67 & 5.5 & 7 \\
\hline 7 & $\begin{array}{l}\text { GA } \\
\text { PMC } 874\end{array}$ & $8 x$ & Upland & 232 & 150 & 391 & & & & 3 & 8 & & & \\
\hline 7 & MS2 & $8 x$ & Upland & 232 & 169 & 985 & 5.67 & 7.2 & 6.5 & 2.3 & 6.7 & 2.83 & 6.5 & 7 \\
\hline 7 & AL3 & $8 x$ & Upland & 232 & 125 & 625 & 5.33 & 6.5 & 6.3 & 1.8 & 6 & 3.17 & 7 & 6.8 \\
\hline 7 & OK 2 & $8 x$ & Upland & 210 & 140 & 619 & 5.67 & 6.5 & 6.3 & 2.7 & 6.3 & 3.33 & 6.5 & 6.5 \\
\hline 7 & $\begin{array}{l}\text { GA } \\
\text { PMC } 1058\end{array}$ & $8 x$ & Upland & 233 & 140 & 1398 & & & & 2 & 6 & & & \\
\hline 7 & $\begin{array}{l}\text { GA } \\
\text { PMC425 }\end{array}$ & $8 x$ & Upland & 236 & 170 & 631 & & & & 2 & 9 & & & \\
\hline 8 & KY 12 & $8 x$ & Upland & 216 & 87 & 220 & 4 & 6 & 6 & 2 & 6 & 1 & & 7 \\
\hline 8 & CIR & $8 \mathrm{x}$ & Upland & 200 & 166 & 1231 & 6.87 & 6.3 & 6.5 & 2.3 & 6.9 & 2.2 & 4.8 & 6.5 \\
\hline 8 & KY 2 & $8 x$ & Upland & 200 & 150 & 776 & 7 & 7 & 6.8 & 3 & 7.7 & 3.33 & 6 & 7 \\
\hline 8 & $\begin{array}{l}\text { GA } \\
\text { PMC188 }\end{array}$ & $8 \mathrm{x}$ & Upland & 203 & 110 & 406 & & & & 2 & 9 & & & \\
\hline 8 & PI 337553 & $8 x$ & Upland & 203 & 129 & 731 & 6 & 8 & 6 & 2 & 6 & 3 & & 6 \\
\hline 8 & KY 1 & $8 \mathrm{x}$ & Upland & 206 & 159 & 948 & 7 & 7.3 & 5.8 & 2.7 & 7.3 & 2.83 & 5.5 & 7 \\
\hline 8 & AR 8 & $8 x$ & Upland & 206 & 125 & 287 & 4.67 & 6.7 & 6 & 2.3 & 6 & 4 & 6 & 5.7 \\
\hline 8 & AR2 & $8 x$ & Upland & 208 & 103 & 399 & 5 & 6.7 & 5.7 & 2.7 & 6.3 & 2 & 7 & 6.7 \\
\hline 8 & KY1625 & $8 x$ & Upland & 209 & 112 & 743 & 6 & 5.9 & 6.9 & 2.5 & 4.8 & 1.5 & 6.78 & 6.8 \\
\hline 8 & Pathfinder & $8 x$ & Upland & 210 & 118 & 1104 & 5 & 7 & 7 & 4 & 6 & 3 & 9 & 6 \\
\hline 8 & GA 1 & $8 \mathrm{x}$ & Upland & 210 & 118 & 323 & 4.67 & 5.7 & 6.7 & 2.3 & 6.7 & 3.67 & 6 & 6 \\
\hline 8 & KY 3 & $8 x$ & Upland & 212 & 131 & 800 & 5.83 & 6.8 & 6.2 & 3 & 6.8 & 4 & 6.5 & 5.5 \\
\hline 8 & Blackwell & $8 x$ & Upland & 212 & 143 & 807 & 6.33 & 6.8 & 5.8 & 3.2 & 7 & 2.33 & 6 & 6 \\
\hline 8 & TN102 & $8 x$ & Upland & 212 & 125 & 640 & 5.33 & 7 & 5 & 3 & 6 & 2.67 & 7 & 3.7 \\
\hline 8 & Caddo & $8 x$ & Upland & 214 & 123 & 1917 & 5 & 7 & 6 & 4 & 3 & 2 & 9 & 6 \\
\hline 8 & $\mathrm{OK} 3$ & $8 x$ & Upland & 214 & 125 & 837 & 6 & 6 & 6 & 4 & 5 & 4 & & 4 \\
\hline
\end{tabular}


Table 36. (Continued)

\begin{tabular}{|c|c|c|c|c|c|c|c|c|c|c|c|c|c|c|}
\hline 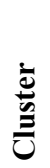 & 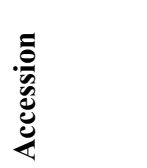 & $\frac{e}{e}$ & $\underset{\substack{0 \\
0}}{\stackrel{0}{0}}$ & 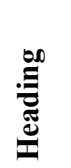 & 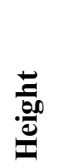 & 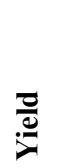 & $\frac{\tilde{z}}{\tilde{z}}$ & 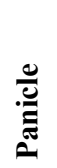 & 苞 & 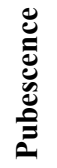 & 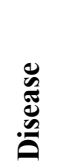 & $\dot{\bar{\theta}}$ & 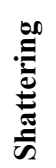 & 苨 \\
\hline 8 & SWG 006 & $8 \mathrm{x}$ & Upland & 215 & 195 & 2163 & 6.83 & 7 & 6.3 & 1.3 & 7.5 & 3.33 & 5.5 & 6.7 \\
\hline 8 & $\begin{array}{l}\text { GA } \\
\text { PMC1012 }\end{array}$ & $8 \mathrm{x}$ & Upland & 215 & 165 & 1626 & & & & 3 & 8 & & & \\
\hline 8 & $\begin{array}{l}\text { GA } \\
\text { PMC920 }\end{array}$ & $8 \mathrm{x}$ & Upland & 215 & 175 & 509 & & & & 2 & 9 & & & \\
\hline 8 & NJ50 & $8 \mathrm{x}$ & Upland & 215 & 155 & 1066 & 5.83 & 7 & 6.8 & 2.8 & 7.2 & 2.67 & 5.5 & 6.8 \\
\hline 9 & Falcon & $8 \mathrm{x}$ & Upland & 168 & 108 & 572 & 5 & 5 & 4 & 4 & 5 & 3 & 6.7 & 5 \\
\hline 9 & NE 28 & $8 \mathrm{x}$ & Upland & 184 & 118 & 775 & 5 & 7 & 5 & 3 & 6 & 3 & 6 & 7 \\
\hline 9 & Shelter & $8 \mathrm{x}$ & Upland & 186 & 142 & 664 & 6.33 & 5.9 & 5.7 & 3.3 & 6.7 & 2.13 & 4.2 & 6.8 \\
\hline
\end{tabular}




\section{REFERENCES}

Burton, G. W. 1974. Recurrent restricted phenotypic selection increases forage yields of Pensacola bahia grass. Crop Sci. 14:831-835.

Burton, G. W. 1982. Improved recurrent restricted phenotypic selection increases bahiagrass forage yields. Crop Sci. 22:1058-1061.

Eberhart, S. A., and W. A. Russel. 1966. Stability parameters for comparing varieties. Crop Sci. $6: 36-40$.

Finlay, K. W., and G. N. Wilkinson. 1963. The analysis of adaptation in a plant breeding program. Aust. J. Agric. Res. 14:742-754.

Kang, M. S., and J. D. Miller. 1984. Genotype X environment interactions for cane and sugar yield and their implications in sugarcane breeding. Crop Sci. 24:435-440.

Shukla, G. K. 1972. Some statistical aspects of partitioning genotype-environmental components of variability. Heredity 29:237-245.

Van Esbroeck, G. A., M. A. Hussey, and M. A. Sanderson. 1998. Selection response and developmental basis for early and late panicle emergence in Alamo switchgrass. Crop Sci. 38:342-346.

Wricke, G. 1962. Uber eine Methode zur Erfassung der ökologischen Streubreite. Zeitung für Pflanzenzüchtung 47:92-96. 



\section{APPENDIX}

\section{SCALE-UP AND COMMERCIALIZATION OF NEW SWITCHGRASS CULTIVARS}





\title{
APPENDIX
}

\section{SCALE-UP AND COMMERCIALIZATION OF NEW SWITCHGRASS CULTIVARS}

\author{
C. M. Taliaferro \\ Plant \& Soil Sciences Department \\ Oklahoma State University \\ Stillwater, OK 74078 \\ K. P. Vogel \\ Agricultural Research Service, USDA \\ University of Nebraska \\ PO Box 830973 \\ Lincoln, NE 68583 \\ J. H. Bouton \\ Crop \& Soil Sciences Department \\ University of Georgia \\ Athens, GA 30602 \\ SUBMITTED TO \\ S. B. MCLAUGHLIN \\ HERBACEOUS TASK LEADER \\ BIOFUELS FEEDSTOCK DEVELOPMENT PROGRAM \\ OAK RIDGE NATIONAL LAB \\ PO BOX 2008, MS 6422 \\ OAK RIDGE, TN 37831-6422
}

MARCH 2000 



\section{INTRODUCTION}

A substantial research and development program was launched in 1992 by the ORNL-BFDP to develop herbaceous species as dedicated feedstock crops for bioenergy production. Switchgrass, Panicum virgatum (L.), was chosen as the model herbaceous species for initial R\&D on the basis of its wide natural distribution in North America, high biomass production capability, and desirable environmental benefits ( McLaughlin, 1992; McLaughlin et al., 1996). The R\&D effort has focused on determining best establishment and production practices for switchgrass and on its breeding improvement. Technology advances in these areas are necessary to achieve the scale and economy of production necessary for successful deployment of bioenergy crops like switchgrass.

The switchgrass breeding effort is charged with supplying adapted commercial cultivars with enhanced performance capability for varied climatic and edaphic conditions. BFDP sponsored switchgrass breeding research is underway in Nebraska, Georgia and Oklahoma, with some additional effort in Tennessee and Wisconsin. New cultivar releases are expected from these programs in the near future and thereafter on a sustained basis as incremental improvements are attained through the breeding process. This document is intended to serve as a planning guide for the release of new switchgrass cultivars developed with the support of ORNL-BFDP.

\section{TYPES OF SWITCHGRASS CULTIVARS}

Switchgrass is a long-lived perennial that reproduces by seed. The reproductive mode is sexual and outcrossing results from cross-pollination enforced by strong self-incompatibility. Switchgrass cultivars have traditionally been sexually propagated via seed and new cultivars emanating in the near future from current breeding programs will be the same. The new cultivars are expected to be either: 1) broad genetic base plant populations, 2) synthetics involving a few ( 2-12) selected parent plants, or 3) $\mathrm{F}_{1}$ hybrids. The distinction between 2-clone synthetic and $F_{1}$ hybrid switchgrass varieties is somewhat gray, but the basic distinction rests on whether generations beyond the $F_{1}$ are permitted. The Federal Seed Act requires that seed sold as " $F_{1}$ hybrid" must comprise at least $75 \%$ hybrid seed (FSA Sec. 201.11a). Some states require that more than $75 \%$ of pure seed be hybrid in order to be labeled and sold as such. Two highly selfincompatible ( $\sim 1-2 \%$ selfed seed set) switchgrass plants cloned in alternating rows in a production field would produce in excess of $95 \%$ hybrid seed.

The fidelity of cultivar types 1 and 2 is best maintained under a certified seed production system that limits seed increase to two or three generations beyond basic (breeder class) seed. Federal and state laws govern the production and sale of certified seed. The fidelity of cultivars under certification is ensured because certified seed fields have to be isolated from other plants of the same kind by distances that prevent or minimize genetic and mechanical contamination. Pedigree seed classes are termed 'breeder', 'foundation', 'registered', and 'certified'. For cultivar types 1 and 2, breeder seed is usually the seed that is produced by intercrossing a selected set of parent plants. Intercrossing is normally accomplished by growing the selected parent plants in an isolated field "polycross" nursery. Seed beyond the $1^{\text {st }}$ generation (Syn-1) may be classified as "breeder seed" at the discretion of the Breeder. Under this system, breeder seed is used to establish plantings that will produce foundation seed, which in turn is used to produce registered seed, and so on.

No commercial $\mathrm{F}_{1}$ hybrid switchgrass cultivar has been produced to date, but it is technically feasible to produce such seed. An $\mathrm{F}_{1}$ hybrid cultivar could potentially be developed by mass clonal propagation of two highly self-incompatible parent plants and transplanting these in mixture (perhaps alternating rows) in seed production fields. Recent technology perfected by tissue/cell culture specialist Bob Conger through ORNL-BFDP supported research at the University of Tennessee enables the mass cloning of individual plants (Alexandrova et al., 1996a \& 1996b). 


\section{CULTIVAR RELEASE PROCEDURES}

Specific release procedures of new switchgrass cultivars from ORNL-BFDP contract research will be dictated and governed by the policies of the contracted institutions conducting the breeding and thereby owning the cultivar. In general, public institutions now release plant cultivars either without restriction or with restrictions. Cultivars released without restriction are available to the general public without limitation on use or sale of propagating material except for those specified in the release notice or required by seed certification laws. The initial increase of propagating stock is usually handled by a foundation seed service, but there is no requirement for producers of propagating stock to maintain the cultivar under certification.

Restrictions on how cultivars are produced or marketed, or both, are achieved through intellectual property protection or licensing, or both. Sexually reproduced cultivars may be protected against unauthorized use via the Plant Variety Protection Act (PVPA), or through the granting of a utility patent if developed by "non-obvious" means beyond manipulating "products of nature". For most switchgrass varieties, the likely means of protection will be achieved through the PVPA. Protection was extended to $\mathrm{F}_{1}$ hybrid cultivars by the1994 PVPA Amendment Act. The certification option within the PVPA mandates that seed can be sold by cultivar name only as a class of certified seed. Private grass seed companies began releasing their cultivars under PVP as soon as the option became available. Until recently, many public forage breeding programs did not release their cultivars under PVPA because of the amount of work and associated expenses of obtaining the data to get PVP registration. Non-certified, unprotected cultivars are at greater risk of having low quality or misrepresented seed, or both, enter the market under the cultivar name. Such problems have been experienced with Alamo switchgrass and Hycrest crested wheatgrass. Consequently, many public programs are starting to release their forage cultivars under PVPA.

The release of new cultivars by public research agencies under exclusive or semi-exclusive licensing arrangements has become increasingly common over the past two decades. This usually places a new cultivar with one to a few companies (grower groups in some cases) who have the exclusive production and marketing rights. The owner is typically remunerated through an agreed upon fee structure usually based on seed sales.

There are arguments for and against exclusive releases by public research agencies, but such releases have generally worked well. This is particularly true for crops like perennial grasses that require specialized seed production and seed processing technology and for which planting seed demand is relatively low compared to major annual food and feed crop species. Exclusive release can be effected in a manner that provides incentive to the licensee(s) to help assure market success of a cultivar by promotion (e.g. advertising) and quality assurance (e.g. maintain the cultivar under certification and sell only high quality seed). New switchgrass cultivars being developed with ORNL-BDP support can likely be most effectively and efficiently delivered to the public through the mechanisms of exclusive release and PVP. There have been some problems with exclusive release of forage cultivars to single companies because of later mergers or mismanagement.

NRCS lists of seed companies specializing in grass seed production and marketing are included in the appendix. The American Seed Trade Association website at www.amseed.com and the Southern Seedsmen's Association website at www.seedsmen.com provide additional listings and information. 


\section{PREPARING FOR RELEASE}

\section{Testing and Characterization of Candidate Cultivars}

The release of a new plant cultivar by a public research agency (or agencies) is contingent on sound scientific data demonstrating that the cultivar is superior to existing commercial standard cultivars in one or more important performance traits, or combination of performance traits. It is incumbent on the breeder to document the performance of breeding materials by adequate testing through space and time. Multi-environment performance testing of switchgrass breeding materials from ORNL-BFDP supported programs is facilitated by the network of scientists and sites available to assist in evaluations. New switchgrass cultivars are expected to conform to the generally recognized criteria of a "variety" i.e. to be identifiable and reproducible within defined levels of variation. The development of descriptive information sufficient to distinguish the new cultivar from existing cultivars is the responsibility of the breeder.

\section{Seed Scale-Up}

Seed scale-up usually begins when experimental breeding lines reach the final stages of evaluation. Such scale-up is necessary to support the generally greater number and larger size of plantings in the final testing. For synthetic cultivars, it is also desirable to have some performance data on generations beyond the Syn-1. The desired amounts of seed may vary from a few kilograms to a few hundred kilograms, depending on the number and size of the final test plantings.

When the Breeder decides to release a new cultivar for commercial production, it is important to have an adequate quantity of breeder class seed to establish the desired amount of foundation class production. Foundation class pedigree seed is generally produced under the auspices of state Foundation Seed Organizations. Functionally, the Breeder and the Foundation Seed Organization usually work together closely to achieve the desired foundation seed increases. The foundation seed is used to establish plantings to produce either registered or certified seed. The registered class has been omitted for all recent switchgrass cultivars because it is not needed to produce adequate quantities of seed.

\section{Switchgrass Seed Production}

Switchgrass seed in commercial channels comes either from "wild" harvests of natural stands or drilled swards, or from dedicated seed production enterprise. This section focuses primarily on the latter. Dedicated switchgrass seed production is currently confined mainly to the Great Plains and Corn Belt states, with the former being the historical region of highest production. Substantial switchgrass seed production occurs in the Great Plains states of Texas, Oklahoma, Kansas, Nebraska, and South Dakota. Switchgrass seed is also produced in Missouri and Iowa.

Moser and Vogel (1995) note that scientific data on switchgrass seed production is sparse. Much of the available information comes from producer experience. Switchgrass seed yields vary greatly depending on cultivar and growing conditions, but typical yields range from 150 to $500 \mathrm{lbs}$. pure seed per acre (PSA). Under optimal conditions PSA yields of $1000 \mathrm{lbs}$. or more are attained. In west Texas and southwestern Oklahoma, 'Alamo' seed yields from irrigated production have averaged around 150 pure live seed (PLS) lbs. acre ${ }^{-1}$, corresponding to about 200-250 lbs. PSA (Turner, 1999). Stock Seed Company, Murdock, NE, obtains PLS yields in the neighborhood of 150-200 lbs. acre ${ }^{-1}$ from upland switchgrass cultivars (e.g. Cave-in-Rock, Pathfinder, Blackwell, NE 28) grown in rows without irrigation (Fritz, 1999). 
Establishing and managing seed production fields. Smith et al. (Undated) provide much practical information on switchgrass seed production in their publication "Native Grass Seed Production Manual". Copies of the two pages of information on switchgrass in this manual are appended. Establishment and production practices across regions will deviate in minor ways from those outlined in this manual, but the information is generally applicable across the current switchgrass seed production area. Seed production fields are usually planted in rows 3 to 3.5 feet apart at seeding rates of 1.5 to 2 PLS lbs. acre ${ }^{-1}$.

The key factors affecting stand establishment are soil moisture and weed competition. Typical management practices for established stands include annual fertilization in the spring with 50 to $100 \mathrm{lbs}$. $\mathrm{N}$ acre ${ }^{-1}$ plus the addition of $\mathrm{P}$ and $\mathrm{K}$ if soil test results indicate low levels. In southern production areas, additional $\mathrm{N}$ at rates of 20 to $40 \mathrm{lbs}$. acre ${ }^{-1}$ may be applied through the irrigation system in mid-summer and again in late summer. Seed production fields are often burned in the late winter or early spring prior to fertilization. Fields planted in rows are often cultivated in spring after burning and prior to fertilization.

Seed is either direct combined or swathed and dried prior to combining. The shorter upland switchgrasses are amenable to direct combining while the much taller and more robust lowland types are not. The indeterminate flowering habit of switchgrass causes seed to mature over a period of 2-4 weeks. Harvest occurs when the majority of the inflorescences have seed in the hard dough stage. Some seed will have shattered by this time.

Time requirement. Seed scale-up of a traditional switchgrass cultivar with breeder, foundation, and certified classes usually requires 3 to 5 years to attain the levels needed for its establishment in commerce. The seed scale-up scenario in Table 1 assumes a planting rate of $2 \mathrm{lbs}$. PLS acre ${ }^{-1}$ and PLS seed yields of 50 and $100 \mathrm{lbs}$. acre $^{-1}$ for establishment year and subsequent years, respectively. The scenario in Table 2 assumes the same planting rate, but PLS seed yields of 50 and $150 \mathrm{lbs}$. acre $^{-1}$ for establishment year and subsequent years, respectively. These are conservative seed yield estimates. Scenarios 1 and 2 would respectively result in 531,250 and 1,125,000 PLS lbs. of certified seed in the fifth production year. These respective amounts would enable the seeding of 100,000 to 200,000 acres of biomass production fields. These scenarios assume good production practices and the ability to minimize the effects of drought. 
Table 1. Time line for seed scale-up of a cultivar with breeder, foundation, and certified seed classes. Assumptions include a seeding rate of 2 pure live seed (PLS) lbs. acre ${ }^{-1}$ and PLS seed yields of 50 and 100 lbs. acre ${ }^{-1}$.

\begin{tabular}{|c|c|c|c|c|c|c|c|c|c|}
\hline \multirow[b]{2}{*}{ Class } & \multicolumn{9}{|c|}{ Years } \\
\hline & 1 & 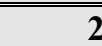 & & & & ra & & & \\
\hline & \multicolumn{9}{|c|}{ |-------------------------------(Cumulative acres) Total PLS lbs.--------------------------- } \\
\hline Breeder $^{\wedge}$ & (1) 50 & (1) & 100 & (1) & 100 & (1) & 100 & (1) & 100 \\
\hline Foundation & & $(25)$ & 1250 & $(75)$ & 5,000 & $(100)$ & 8,750 & $(125)$ & 11,250 \\
\hline Certified & & & & $(625)$ & 31,250 & $(3,125)$ & 187,500 & $(7,500)$ & 531,250 \\
\hline
\end{tabular}

One polycross nursery established with equal numbers of clonal plants of each parent plant in a design to promote random intercrossing. Plants could be spaced about 3 feet apart. Foundation and certified production fields established by seeding in rows.

Table 2. Time line for seed scale-up of a cultivar with breeder, foundation, and certified seed classes. Assumptions include a seeding rate of 2 pure live seed (PLS) lbs. $\mathrm{acre}^{-1}$ and PLS seed yields of 50 and $150 \mathrm{lbs}$. $\mathrm{acre}^{-1}$.

\begin{tabular}{|c|c|c|c|c|c|c|c|c|}
\hline \multirow[b]{2}{*}{ Class } & \multicolumn{8}{|c|}{ Years } \\
\hline & 1 & 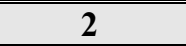 & & & & 4 & & 5 \\
\hline & \multicolumn{8}{|c|}{ 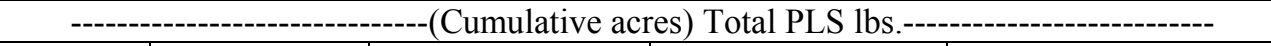 } \\
\hline Breeder $^{\wedge}$ & (1) 50 & 150 & $(1)$ & 150 & $(1)$ & 150 & $(1)$ & 150 \\
\hline Foundation & & 1250 & $(100)$ & 7,500 & $(175)$ & 18,750 & $(250)$ & 30,000 \\
\hline Certified & & & $(625)$ & 31,250 & $(4,375)$ & 281,250 & $(13,750)$ & $1,125,000$ \\
\hline
\end{tabular}

One polycross nursery established with equal numbers of clonal plants of each parent plant in a design to promote random intercrossing. Plants could be spaced about 3 feet apart. Foundation and certified production fields established by seeding in rows.

The time line for scaling up production of $F_{1}$ hybrid cultivars would depend on the capability of mass cloning the two parent plants. Plants equally spaced 3.5 feet (rows and plants in rows spaced 42 inches) would require 3,556 plants acre ${ }^{-1}$ (1778 clonal plants of each parent). A 100-acre field would then require 355,600 plants, or 177,800 plants of each parent. Assuming PLS yields of 50 and $150 \mathrm{lbs}$. acre ${ }^{-1}$ in the $1^{\text {st }}$ and subsequent years, respectively, the yields from the 100 acre field would then be 5,000 lbs. in year 1 and 15,000 lbs. in subsequent years. 


\section{References}

Alexandrova, K. S., P. D. Denchev, and B. V. Conger. 1996a. Micropropagation of switchgrass by node culture. Crop Sci. 36:1709-1711.

Alexandrova, K. S., P. D. Denchev, and B. V. Conger. 1996b. In vitro development of inflorescences from switchgrass nodal segments. Crop Sci. 36:175-178.

Fritz, Rod. 1999. Personal Communication. Stock Seed Farms, 28008 Mill Rd., Murdock, NE.

McLaughlin, S. B. 1992. New switchgrass biofuels research program for the Southeast. In "Annual Auto. Tech. Dev. Contract Meeting", pp 111-115, Dearborn, MI

McLaughlin, S. B. and M. E. Walsh. 1998. Evaluating environmental consequences of producing herbaceous crops for bioenergy. Biomass and Bioenergy 14:317-324

Moser, L. E. and K. P. Vogel. 1995. Switchgrass, big bluestem, and indiangrass. Pp 409-420 In Barnes, R. F, D. A. Miller, and C. J. Nelson (Eds.) Forages Volume 1: An Introduction To Grassland Agriculture. $5^{\text {th }}$ Ed., Iowa State Univ. Press, Ames, IA

Smith, S. R. Jr. and Smith, S. (Eds.). Undated. Native Grass Seed Production Manual. USDA-NRCS, Ducks Unlimited Canada, Manitoba Forage Seed Assoc., and Univ. Manitoba.

Turner, Dorcy. 1999. Personal Communication. Bob Turner Seed Company, Rt. 1, Box 292, Breckenridge, TX 


\section{INTERNAL DISTRIBUTION}

1-10. J. H. Cushman, 1059, MS-6422

11. S. G. Hildebrand, 1505, MS-6037

12-14. ESD Library

15. ORNL Central Research Library

16. ORNL Laboratory Records-RC

\section{EXTERNAL DISTRIBUTION}

17-21. C. Taliaferro, Oklahoma State University, Plant \& Soil Sciences Department, 368 Ag Hall, Stillwater, OK 74078-6028

22. R. Costello, U.S. Department of Energy, Office of the Biomass Program, Forrestal, 1000 Independence Avenue, SW, EE-2E, Washington, DC 20585

23. M. E. Decot, U.S. Department of Energy, Office of the Biomass Program, Forrestal, 1000 Independence Avenue, SW, EE-2E, Washington, DC 20585

24. P. E. Grabowski, U.S. Department of Energy, Office of the Biomass Program, Forrestal, 1000 Independence Avenue, SW, EE-2E, Washington, DC 20585

25. G. Santos-Leon, U.S. Department of Energy, Office of the Biomass Program, Forrestal, 1000 Independence Avenue, SW, EE-2E, Washington, DC 20585

26. S. A. Sprague, U.S. Department of Energy, Office of the Biomass Program, Forrestal, 1000 Independence Avenue, SW, EE-2E, Washington, DC 20585

27. S. N. G. Tagore, U.S. Department of Energy, Office of the Biomass Program, Forrestal, 1000 Independence Avenue, SW, EE-2E, Washington, DC 20585 